Portland State University

PDXScholar

\title{
Transportation and Land Use Patterns: Monitoring Urban Change Using Aerial Photography, Portland, Oregon 1925-1945
}

Paul Hagen Fyfield

Portland State University

Follow this and additional works at: https://pdxscholar.library.pdx.edu/open_access_etds

Part of the Human Geography Commons, Physical and Environmental Geography Commons, and the Urban Studies Commons

Let us know how access to this document benefits you.

\section{Recommended Citation}

Fyfield, Paul Hagen, "Transportation and Land Use Patterns: Monitoring Urban Change Using Aerial Photography, Portland, Oregon 1925-1945" (2003). Dissertations and Theses. Paper 2242.

https://doi.org/10.15760/etd.2239

This Thesis is brought to you for free and open access. It has been accepted for inclusion in Dissertations and Theses by an authorized administrator of PDXScholar. Please contact us if we can make this document more accessible: pdxscholar@pdx.edu. 
TRANSPORTATION AND LAND USE PATTERNS:

MONITORING URBAN CHANGE USING AERIAL PHOTOGRAPHY, PORTLAND, OREGON 1925-1945

by
PAUL HAGEN FYFIELD

A thesis submitted in partial fulfillment of the requirements for the degree of

\author{
MASTER OF SCIENCE \\ in \\ GEOGRAPHY
}

Portland State University

2003 
THESIS APPROVAL

The abstract and thesis of Paul Hagen Fyfield for the Master of Science in Geography were presented May 20, 2003, and accepted by the thesis committee and the department

COMMITTEE APPROVALS:
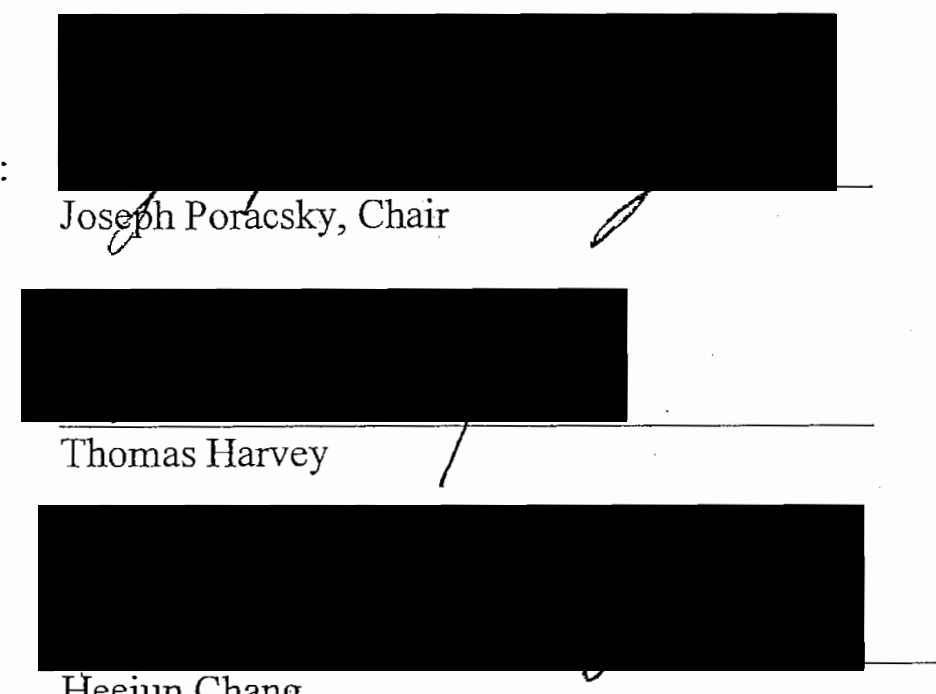

Heejun Chang

DEPARTMENT APPROVAL:

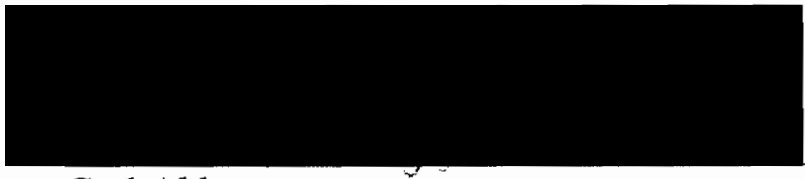

Carl Abbott

Representative of the Office of Graduate Studies

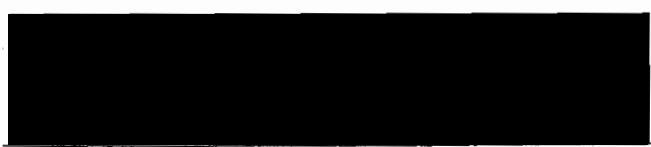

Teresa Bulman, Chair

Department of Geography 


\begin{abstract}
An abstract of the thesis of Paul Hagen Fyfield for the Master of Science in Geography presented May 20, 2003.

Title: Transportation and Land Use Patterns: Monitoring Urban Change Using Aerial Photography, Portland, Oregon 1925-1945
\end{abstract}

American urban neighborhoods are a patchwork; the spatial arrangement of types is a reflection of the dominant transportation technology at the time of their development. The earliest suburban areas were made accessible by fixed route systems such as the electric streetcar, followed by the widespread adoption of the automobile; each transportation epoch resulted in characteristic patterns of land use. This study uses aerial photographic coverage of Portland, Oregon from the years 1925, 1936, and 1945, a time of decline for the once popular trolley lines and dramatic increase in automobile usage, to monitor change within the residential areas of Portland's east side over a twenty year period.

Classic economic models of the time acknowledged transportation as a force shaping the city; modern ideas in urban planning such as Traditional Neighborhood Design and Transit Oriented Development look to pre-automobile urban form as a means to reduce automobile use and its negative implications. This study uses 
variables of housing density and street connectivity derived from the aerial photography; the measured values of these variables are then considered for their spatial and temporal distribution using statistical comparisons. The results are compared to ideas within the urban models and current thinking about urban morphology. While generally consistent with the expected patterns, deviations and differences between the two variables are considered for their implications.

Models offer a simplified version of the growth of American cities, considering only a few of the many aspects of a dynamic environment. By isolating on these variables of density and connectivity, a greater understanding of their role in arriving at the modern residential urban environment may be reached, and this understanding can add to the discourse in current planning debates. 
For my wife, Margie 


\section{ACKNOWLEDGEMENTS}

I owe a debt of gratitude to all the members of my committee, Dr. Tom Harvey, Dr. Heejun Chang, Dr. Carl Abbott, and my advisor Dr. Joe Poracsky, for their assistance in the completion of this thesis. Each made important contributions that improved the final result. I would also like to thank Dr. Ric Vrana for his encouragement and interest in this topic during its formative stages.

Special thanks go to Brian Johnson of the Stanley Parr Archives and Records Center and Elizabeth Winroth of the Oregon Historical Society for breaking with policy, and taking the time to personally transport the aerial photographs used in this thesis to my workplace, the BLM Oregon State Office, for scanning on a large format scanner, and waiting patiently. Henry Wolter, Jim Rounds and Greg Chan of the BLM all assisted in the process of acquiring and working with these images.

Dr. Robert Johnston's research into the political history of Portland's eastside demonstrated to me the value of understanding past processes. What began as a notso-straightforward cartographic commission for his recently published book, and our voluminous correspondence as he explained the forces behind the patterns I was mapping, sparked an interest in the development of the city that has become my home.

Of course, my greatest appreciation is reserved for my wife, Dr. Margie Fyfield, for her support as I worked towards this degree. Our promise to help one another complete our educations has taken nearly twenty years to come to fruition, but like many things that do not happen easily, it has been a worthy pursuit. 
TABLE OF CONTENTS

PAGE

ACKNOWLEDGEMENTS …………....................................................... ii

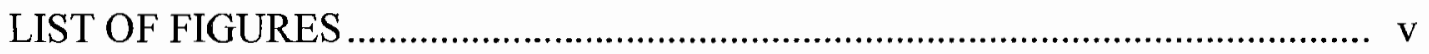

CHAPTER

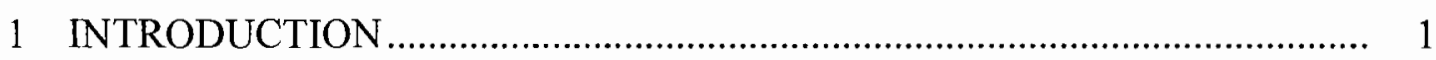

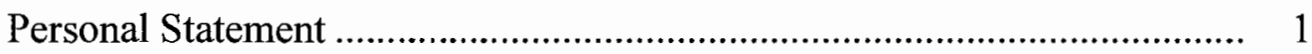

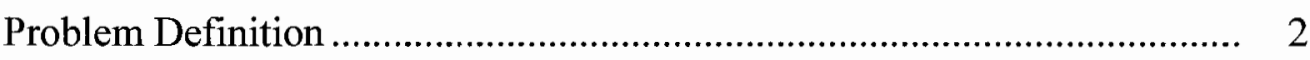

Data

Hypothesis and Outline ......................................................................... 6

2 HISTORIC CONTEXT AND MODERN CONCERNS...................................... 8

Classic Urban Models....................................................................... 8

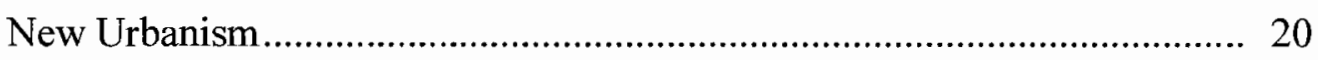

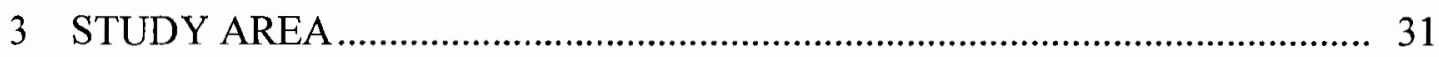

Spatial Extent: Portland's Eastside ............................................................ 31

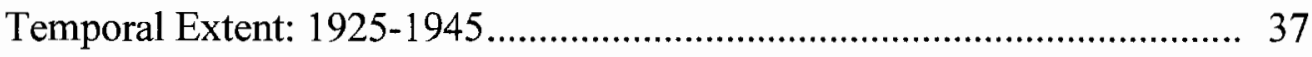

4 DATA COLLECTION ………….............................................................. 46

Source: Aerial Photography ................................................................. 46

Neighborhood Examples ....................................................................... 48

Variables and Sampling Frame ……………........................................... 61 


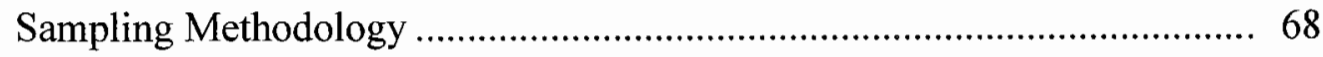

Digitizing and Attribution .............................................................. 71

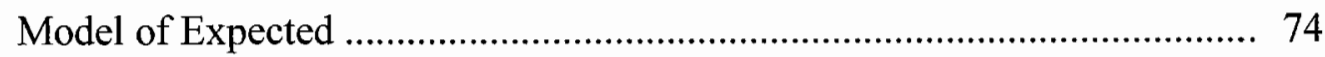

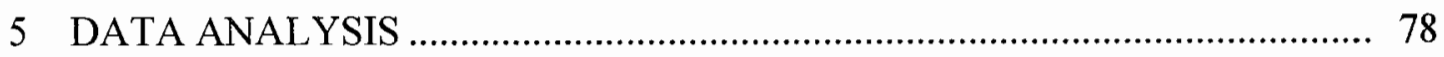

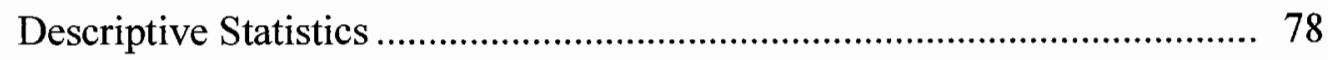

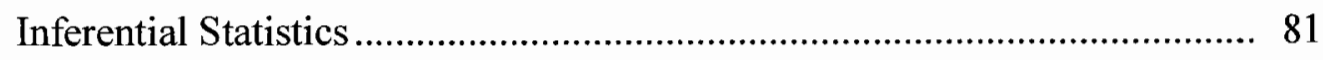

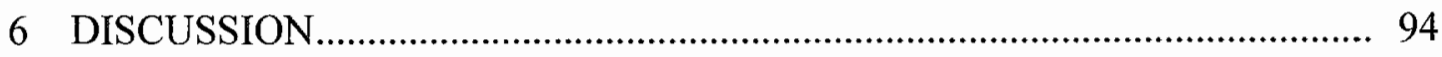

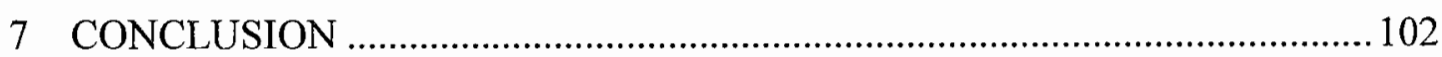

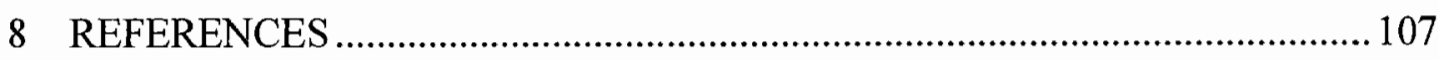

APPENDICES

A Aerial Photography Acquisition ....................................................... 111

B Construction of the Sample Frame ......................................................... 112

C Spatial Attributes of Sample Cells ........................................................... 113

D Density and Connectivity Measures …................................................... 116

E Inferential Test Results.................................................................... 119 


\section{LIST OF FIGURES}

PAGE

1 Classic Models of Urban Form, 1925-1945 ……….................................... 9

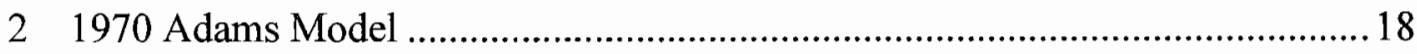

3 Clarence Perry and Andres Duany Neighborhood Designs ................................22

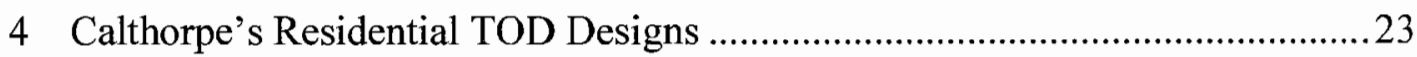

5 Southworth's Historic Analysis of Street Networks ……………………….......25

6 Southworth's Comparison of Traditional and New Urbanist Street Networks...26

7 Krizek's Aerial Photography with 150 Meter Grid Cell .....................................29

8 Portland's Topography and Extent of Streetcar Network …………....................32

9 Portland's Population Trends 1900-1920 ……………….................................35

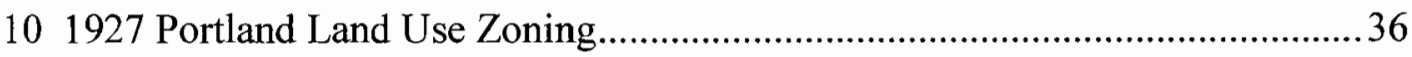

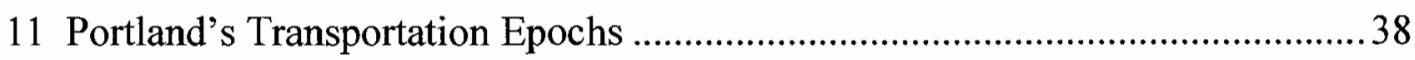

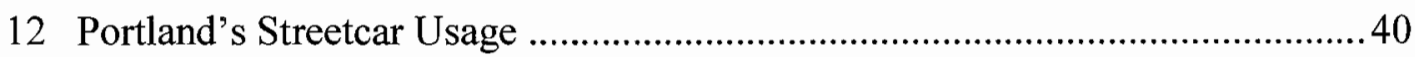

131925 Aerial Photograph of Inner Southeast Area.................................................43

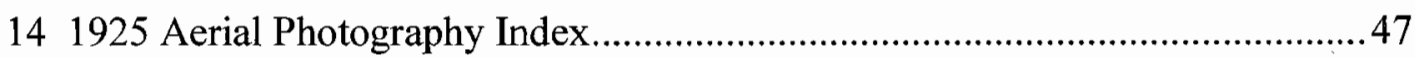

15 Locations of Aerial Photography Neighborhood Examples..................................49

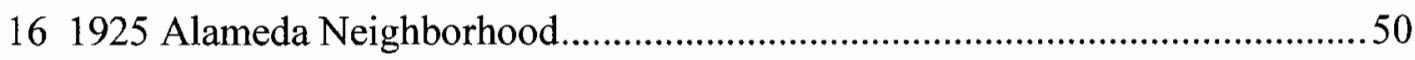

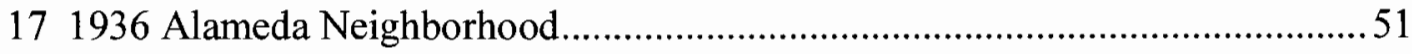

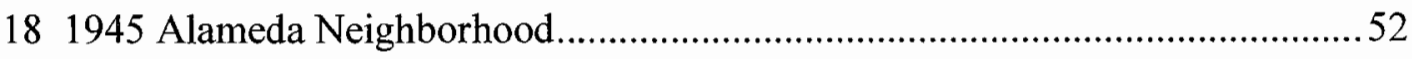

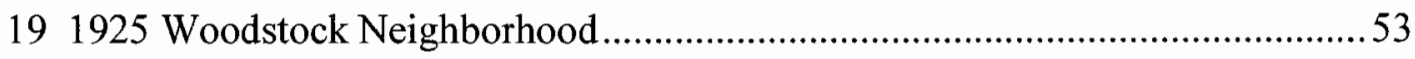




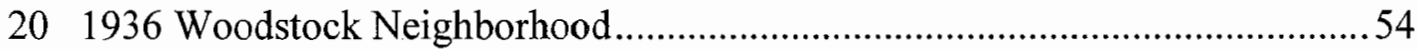

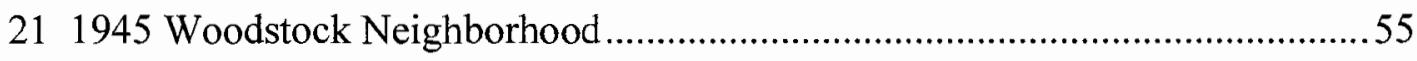

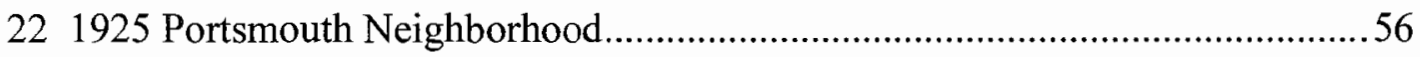

231936 Portsmouth Neighborhood.......................................................................57

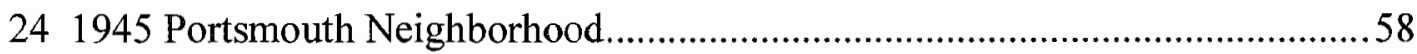

25 Study Area Sample Frame .........................................................................65

26 Study Area Sample Frame Attributed with Distance to the Streetcar Lines ......66

27 Study Area Sample Frame Attributed with Distance to City Hall ......................67

28 Sample Cells Selected from Sample Frame .................................................... 70

29 Building Locations Digitized within a Grid Cell from 1925 to 1945 ...................73

30 Spatial-Temporal Model for Comparison of Variable Measurements ................. 75

31 Model of Expected Comparative Variable Measurements....................................77

32 Dwelling Unit Density Descriptive Statistics..................................................

33 Street Network Connectivity Descriptive Statistics ................................................ 80

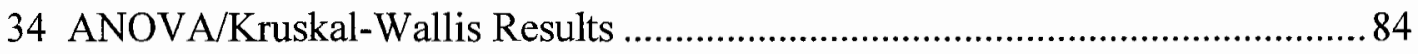

35 Matched Pairs Estimates of Differences in Means............................................... 85

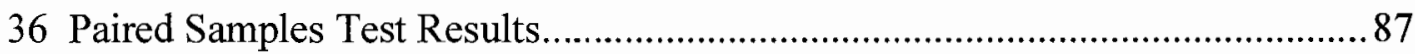

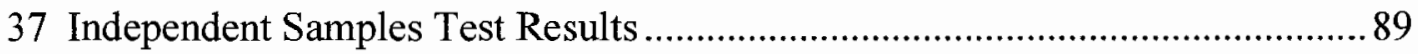

38 Descriptive Statistics in Relation to Distance from City Hall ...............................91

39 Summary of Test Results in Relation to Distance from City Hall .......................93

40 Pedestrian Network in 1925 Aerial Photography .............................................101 


\section{Chapter 1: Introduction}

\section{$\underline{\text { Personal Statement }}$}

The subject of this thesis is not unfamiliar to me. I have been a resident of Portland for the last twenty years, the vast majority of which were spent living in the close-in southeast area of the city. Downtown Portland has been a daily destination, either for my job, or to attend classes at Portland State University, or both. I have always commuted by foot, every morning joining the legion of pedestrians whose paths meet at the Hawthorne, easily the most pedestrian-friendly of Portland's many bridges.

A person walking through his or her environs spends more time experiencing and observing the surroundings than the typical automobile commuter. Changes matter more to the pedestrian; things do not move past so quickly. The characteristics of neighborhoods change, but the borders can be hard to distinguish. The nature of a particular area can be hard to quantify. Sometimes the houses display ornate architectural detailing and present themselves proudly to the street; a short distance later, all one can see from the sidewalk is a garage door. The spatial arrangement of such different neighborhood types initially seems random, without any rhyme or reason.

I purchased my home ten years ago, a true fixer-upper Arts and Crafts style house built in 1913, old by Portland standards. The only reservation my wife and I had was the heavy traffic on the street, uncharacteristically wide for a residential 
neighborhood. My wife became heavily involved in the process of having a "trafficcalming" project — speed project and traffic circles — built on our street. Despite a level of resistance small but still surprising to us in its determination, this effort was ultimately successful.

A traffic circle was installed on the corner directly in front of our house, and the first step of its construction was to dig a gigantic hole in the street. Much to my surprise, this exposed a set of tracks. I had heard that a streetcar had once made its way up our street, but this tangible evidence brought it home and piqued my curiosity. I was interested in learning the history of the streetcar and thought about its effects on the development of Portland's inner neighborhoods. As I walked to work or to school, I found myself thinking about the changes in the surrounding neighborhoods in the context of their proximity to old streetcar lines. I imagined that there was a correlation between neighborhood type and this variable, distance to the trolley line. It must certainly have been an important consideration, I felt, to the original inhabitants of the area, Portland's suburban pioneers. The pattern of neighborhoods suddenly seemed not quite so random.

\section{Problem Definition}

This paper is an attempt to quantitatively understand some aspects of such residential patterns. This is done in the context of classic urban models of the period as well as current ideas regarding historical urban development. The focus is on the early developmental stages of suburban residential growth, in those areas that were 
once the fringe but have come to be considered thoroughly urban as the city continues to grow outward, and highways opened up more land beyond earlier boundaries.

The forces directing urban growth are varied and complex. The function of a model is to simplify reality by eliminating variables and concentrating on only a few, then to examine their significance. In geography, measurements of distance and area are the norm, used to determine the spatial distribution of some variable. Longitudinal studies also consider changes in variables over the course of time.

The impetuses that first motivated urban residents to move outward had both push and pull elements. A desire to escape the overcrowded conditions of the city was coupled with a romantic notion of life in the countryside. This idea originated in Britain and was fueled by the art and literature of the seventeenth and eighteenth centuries, and evolved into part of the popular American culture (Southworth and BenJoseph, 1997). The development of not only transportation, but other technologies to deliver services such as communication allowed the city to grow while still remaining centralized in its administration, rather than "semi-autonomous subcities which would have had to duplicate many of the services and facilities offered in other parts of the city" (Warner, 1978, 16). What was once available only to the wealthy became an option for those whose lives depended on daily access to and communication with the city, and as a result "the single-family dwelling became the paragon of middle-class housing, the most visible symbol of having arrived at a fixed place in society, the goal to which every decent family aspired" (Jackson, 1985, 50). 
Early growth associated with a streetcar system was constrained to the area within walking distance to a trolley line; "only with the coming of the automobile ...could the group able to live beyond walking distance from the outlying (trolley) station increase significantly in numbers" (Vance, 1990, 439). Before the invention of the automobile, there was some control over the placement and form of the growth: some concept, some plan, some constraint was in place. The relatively haphazard type of growth associated with the new transportation alternative, the car, led to an increased emphasis on planning (Southworth and Ben-Joseph, 1997, 68). Clarence Perry was among those advocating a more thoughtful arrangement of land uses. Perry's "neighborhood unit" concept placed all needs of the community not farther than half a mile from a central school, forming a "fractional urban unit that would be self-sufficient yet related to the whole" (Southworth and Ben-Joseph, 1997, 68).

Reality departed from such idealistic constructions. The freedoms exercised by the multitude of new suburbanites resulted in a landscape devoid of compromise for the greater good, assuming such a thing could even be agreed upon. "We don't have the luxury of a single artist whose unconscious process will produce wholeness spontaneously, without having to understand it - there are simply too many people involved (Alexander et al., 1987, 18)," yet "What happens in the city, happens to us. If the process fails to produce wholeness, we suffer right away." Lynch referred to a city's "legibility," the degree to which a city's inhabitants can recognize that "its parts... (are) organized into a coherent pattern" (Lynch, 1960,2). This paper seeks to 
make some sense of the changes occurring in one place, over one twenty-year period. Larger questions are left to larger forums; this is just a small piece of the puzzle. $\underline{\text { Data }}$

Aerial photography, made possible by the advancement of two technologies, flight and photography, is used to measure changes in Portland between 1925 and 1945. Eliel (1959) traces the origins of aerial photography back to the mid-nineteenth century, when rudimentary photographic devices combined with a hot air balloon were used to assist in the creation of maps in France. After several small steps in the improvement of lenses and one huge leap with the invention of the airplane in 1903, development of the technology rapidly and suddenly accelerated, as is so often the case, with the advent of war, in this case World War I.

The usefulness of maps made from pieced-together photographs became apparent during the wartime period, but the science of photogrammetry, in which accurate geographical information can be determined from aerial photographs, was not born until the late 1920s (Eliel, 1959). Within a few more decades enough quality historic imagery had been captured that the use of aerial photography in change detection studies was possible, including analyses of the urban environment such as those by Richter (1969) and Howlett (1963).

The advantage of photography over census-type data sources is that the user is not constrained to any pre-existing analysis units, such as census blocks or tax lots. This can be an important consideration. A researcher might be interested in some phenomenon best delineated in a different manner, or in historic factors not reflected 
in up-to-date information. The area under study is actually seen with one's own eyes. The interpretation is therefore much more direct, even if from a distant vantage point. There is no question of data being incorrectly recorded (at least not by anybody else). The disadvantage of aerial photography is that information is gathered on only physical aspects of the environment. Those interested in socio-economic data must look elsewhere, or use indirect interpretive methods.

\section{Hypothesis and Outline}

The hypothesis of this paper is that a change in transportation technology resulted in a change in land use patterns. Specifically, in Portland, Oregon the abandonment of a streetcar system in favor of the automobile altered the way the city subsequently grew. Time will serve as a proxy variable for transportation change, rather than comparing transportation data directly to land use. Change will be measured between the years 1925 and 1945 , a period of transition in transportation usage.

Before limiting my study to a particular area I will first discuss the larger historical context. Much of the seminal work influencing the understanding of American urban morphology was published over the same time span that is being considered here. Some later work building upon these models will be introduced; these extend the models to variables measurable by aerial photographic interpretation. Present day urban planning concepts, specifically those collectively referred to as "New Urbanism," that look backwards to pre-automobile urban form for inspiration also add to the discussion. I will limit the study area to the extent of Portland's 
streetcar suburbs. I will define this area and justify my definition. Since the study area has temporal limitations as well, I will demonstrate that the years in question represent a shift in dominant transportation modes from streetcar to automobile. My choice of variables, data acquisition methods, sampling and analysis comprise the latter part of this thesis. I will explain the process of incorporating the data into a Geographic Information System (GIS). The data will be compared over time and space; what is expected based on the urban models and other conceptions of urban growth patterns will be compared to what is observed for the study area. Finally, I will interpret and discuss the findings and their meaning, and offer some suggestions for possible future studies. 


\section{Chapter 2: Historic Context and Modern Concerns}

\section{Classic Urban Models}

Any discussion of urban morphology over this particular time span must first acknowledge the contributions of the classic urban models of Burgess, Hoyt, and Harris and Ullman, illustrated in Figure 1.

E.W. Burgess published his concentric zone model in 1925, suggesting that higher status neighborhoods were moving outward from the urban core, forming a series of rings in which social standing was positively correlated with distance from the center. Each zone experienced a pattern of invasion and succession "in response to a new stimulus or situation" (Park et al., 1925, 58), an idea influenced by Burgess' background in plant and animal ecology (Scargill, 1979). The mere fact that this level of outward movement was possible indicates the important role played by transportation, compared to the compact pedestrian city.

Burgess' study was specific to the city of Chicago, but he considers the entire metropolitan area "to be defined by that facility of transportation that enables a business man to live in a suburb of Chicago and to work in the loop, and his wife to shop at Marshall Field's and attend grand opera in the Auditorium" (Park et al., 1925, 49-50). The simplicity of this model belies its importance in recognizing that the compact form of the pedestrian city, in which the population generally lived and worked in the same location, was no longer the norm, and that newer development was exhibiting an identifiable pattern. 


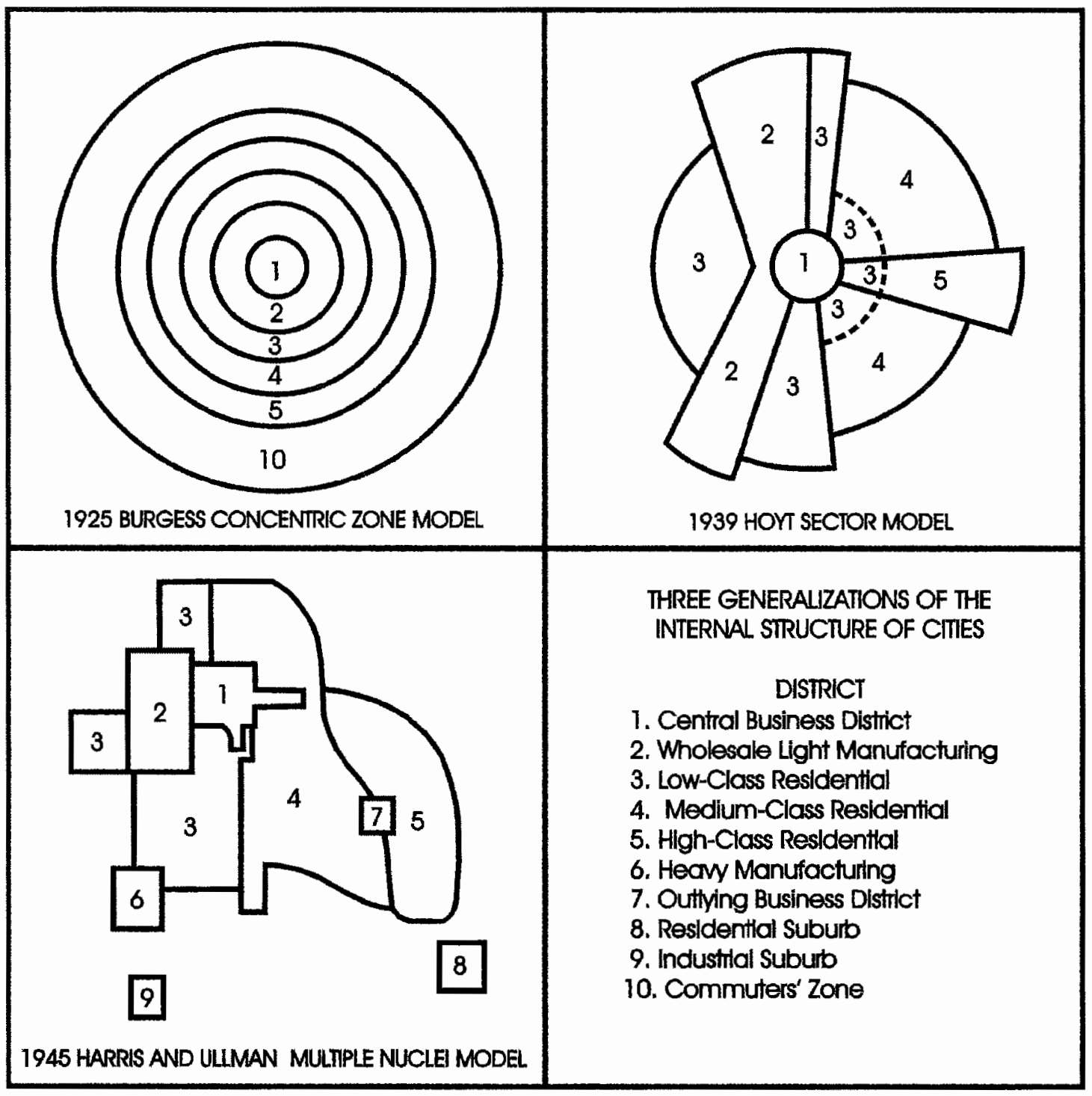

Figure 1: Classic Models of Urban Form, 1925-1945

These models seek to explain the patterning of urban growth in American cities. The emphasis is on socioeconomic variables rather than measures of the physical environment. Though often interpreted as contradictory with one another, they can also be viewed as complimentary, each explaining the spatial distribution of different variables. (Adapted from Harris and Ullman, 1945) 
Dominant physical features — such as Lake Michigan — can complicate any specific situation. While Burgess "has been criticized for ignoring the effects of topography" (Scargill, 1978, 36), in fact he addressed this issue in another paper published in 1929. The brevity of his explanation allows it to be reproduced essentially in its entirety:

Elevation, which is a chief factor in complicating the zonal pattern of urban formation just outlined, is absent in Chicago. In cities of hills and valleys like Montreal or Seattle, which have been examined for comparative purposes, it is interesting to note that elevation introduces another dimension into the zonal pattern. In a plains city the favored residential sections are farthest out; in a hills city, farthest up. The zonal pattern still holds in Montreal and Seattle, but with the poor in the valleys, the well-to-do on the hillsides, and the wealthy on the hilltops. The mountain tops in the Los Angeles area have become the commanding sites for the homes of millionaires. (Burgess, 1929, 119)

Meyer has seized upon this less-known idea and found several significant positive correlations between elevation and neighborhood status in cities of New England (Meyer 1994) and the American West (Meyer 2000), using 1990 census data. Interestingly, Portland was included in the latter study, and was determined to better demonstrate the elevation model than the concentric zone model. Anyone familiar with the city will understand that many of Portland's highest status neighborhoods are also the highest physically, sitting atop the prominent West Hills directly behind the central business district, keeping these areas close to the core but providing the separation of altitude. 
Homer Hoyt published his sector model in 1939, a much more extensive study sponsored by the Federal Housing Authority, which was seeking information to guide government home lending policies, much expanded in response to the Depression. The focus was therefore economic rather than social, primarily concerning land values as indicated by rent. Hoyt determined that residential land uses and neighborhood types radiated outward from the city center in wedge-shaped sectors. McKenzie (1933, 175) had earlier proposed that the concentric circle was too simplistic a representation and suggested instead that "expansion is likely to follow radial lines" in the urban fringe areas. Hoyt expands on this idea in much greater detail. Vance considers this type of growth to be simply a numbers game. "There were never so many truly wealthy families that a complete annular ring of their housing might surround a city" (Vance, 1990, 379), he writes; the further out the city grew the more true this statement would become. Rather than contradicting Burgess' findings, Hoyt can be thought of as elaborating upon them, to "have added a directional element" (Scargill, $1979,41)$. The primary variables remain the same, as Hoyt states that "the exact shape of each city is influenced by topography and transportation" (Hoyt, 1939, 12).

The role played by transportation is addressed, as "high grade residential areas tend to develop along the fastest existing transportation lines" (Hoyt, 1939, 118), allowing the affluent access to the central city with the lowest cost in terms of time. The most desirable building locations therefore tended to cling to major transportation routes, such as "the main plank road, horse car, cable car, and suburban railroad routes" (Hoyt, 1939, 118), disrupting the neat concentric rings to create a stellate 
pattern, in which distance to the transportation route and distance to the city center both play a factor. Hoyt referred to this pattern as axial growth, versus the central growth that would result from a transportation mode not constrained to a particular route (Hoyt, 1939).

The advent of the automobile, an example of non-constrained transportation technology, brought about a fundamental shift in the locations most desirable for residential use. It is impossible to improve on Hoyt's own colorful words:

The axial type of high rent area rapidly became obsolete with the growth of the automobile. When the avenues became dangerous speedways, dangerous to children, noisy, and filled with gasoline fumes, they ceased to be attractive to the well-to-do. No longer restricted to the upper classes, who alone could maintain prancing steeds and glittering broughams, but filled with hoi polloi jostling the limousines with their flivvers, the old avenues lost social caste. The rich then desired seclusion - away from the "madding crowd" whizzing by and honking their horns. (Hoyt, 1939, 120)

Based on this statement it seems clear that Hoyt's sector model is a reflection of certain types of transportation, and as such does reflect a particular transportation epoch. Radial patterns result in part from "settled area in the vicinity of transportation lines and the lack of settlement not served by local public conveyances," while subsequently "the automobile opened up new areas on the periphery so that its effect was to add a section built during the automobile age to sections that were the products of street-car transportation" (Hoyt, 1939, 102). Meyer (2002) goes so far as to suggest reversing the sector model, so that distance from rather than proximity to major transportation routes determines the location of the more desirable building 
locations once automobile usage becomes prevalent. Hoyt himself can be maddeningly inconsistent, stating that "it is a noteworthy fact that the manner in which cities have grown has not changed with the evolution in the means of transportation," and a few lines later, "it is true, nonetheless, that certain types of transportation within the city have favored one form of city growth rather than another" (Hoyt, 1939, 101).

Hoyt's analysis of the role played by topography is even muddier. While not specific to a particular location, Hoyt did focus his study on cities of the American Midwest, which tend to be relatively flat. High elevation areas are desirable because of the views they afford and the low risk of flood; however, "lake, bay, river and ocean fronts (Hoyt, 1939, 117)" are also the locations of high status residential areas. While introduced as a factor, the influence of topography is not resolved, and seems contradictory at times.

If the sector model can be seen as indicative of the type of growth associated with a fixed-rail transportation system, the easy interpretation of the multiple-nuclei model published by Chauncy Harris and Edward Ullman in 1945 is that it represents an urban form inherent to the automobile. While the locations of some land uses are established early in a city's history (industry near a river, for example) land uses of later areas of growth are based upon their relationship to each other - some are mutually attractive and others repellant — rather than considerations of topography or transportation. Satellite urban areas, sprung from a different seed, are swallowed up by the expansion of the city, providing alternative destinations for travel. 
Considerations of directional influences are entirely absent from this model, creating an amorphous shape suggesting a relaxation of travel constraints.

Do these models - especially the sector and multiple nuclei models — reflect temporal change? The short answer is: not explicitly. Only six years separate their publication dates. The case could be made that Hoyt was examining cumulative patterns of growth. Urban form, once built, tends not to be unbuilt, with the exception of the vast tracts leveled to build the large highways of the post-WWII era. The process is additive, so a sensitive barometer such as rental value would incorporate factors from previous times. Harris and Ullman, on the other hand, are more forward looking. "The problem is to build the future city in such a manner that the advantages of urban concentration can be preserved for the benefit of man and the disadvantages minimized" (Harris and Ullman 7), they write, though they do not suggest that their model is the means to accomplish this goal. The theme of the journal issue in which they published their theory was "Building the Future City."

Harris and Ullman instead suggest that the three models represent different city types, and that "most cities exhibit... aspects of the three generalizations of the landuse pattern" (Harris and Ullman, 1945, 16). Adams concurs, stating that "the validity (of each model) depends on the set of variables examined" (Adams, 1970, 38). An overlay of sectoral and concentric patterns, each based on different socio-economic variables, creates the pockets of areas described by the multiple nuclei model, according to Adams. 
The reliance on socio-economic measures integral to these models would seem to necessitate data sources beyond those visible in aerial photography. However, by the 1950s aerial photography and photographic interpretation techniques had advanced to the point that they could add to a further understanding of urban growth dynamics, an approach advocated by Branch $(1948,99)$, who suggested that "...theories such as Homer Hoyt's concerning growth of American residential neighborhoods might be tested."

Green and Monier promote the use of aerial photography in several articles published between 1957 and 1959 (Green 1957a, Green 1957b, Green and Monier 1959, Monier and Green 1957), including a back-and-forth response and rebuttal with Witenstein (1957) over the validity of what Green calls the "socio-physical connection" (Green, 1957a, 99). Green considered aerial photography a valuable tool to measure even the types of variables considered in the classic urban models. "The city comprises both a physical system having physical structure and a social system having social structure," Green wrote (1957a, 90), "The two components are not logically separable."

Four variables in particular are proposed by Green to have value in such studies. The first is the delineation of concentric zones with their midpoint in the central business district, "determined by noting major breaks in land use and referring to terrain features and transportation arteries" (Green, 1957a, 91). This approach recalls both Burgess' concentric zones and the directional influences noted by Hoyt; later Alexander would use concentric rings to analyze density measures (Alexander et 
al., 1977). The second variable is a general land use descriptor including such factors as the character of the street network, lot size and mix of land use. The final two variables measure the prevalence of single family homes and the density of housing, measured in dwelling units per block (Green, 1957a). Once zones are determined based on these factors for several American cities, significant differences in socioeconomic variables were found using census data.

Green and Monier never explicitly state what end of the spectrum of such measures as density and land use mix correlate to high social and economic standing. They make statements such as "consistent negative correlations were found between density averages and owner-occupancy, income, and proportions of high occupancy status groups" (Green, 1957a, 94). Were those high density averages or low density averages? They do not say. Perhaps they felt it was not necessary; perhaps they felt such things were assumed. It is entirely possible that within the context of the $1950 \mathrm{~s}$ the qualities they consider desirable are exactly the opposite of those later to be favored by the New Urbanists, such as cul-de-sacs, low density, and strictly separated land use.

Their unwritten hypothesis seems to be that people have as much space as they can afford, and this is probably accurate. When comparing high density streetcar suburbs to low density automobile development, it is important to remember that the land use patterns of the streetcar era were considerably lower density than those of the pedestrian city. In each transition, from pedestrian to streetcar then streetcar to automobile, technological advancement allowed lower density. People fleeing the 
inner city built relatively low density housing along the streetcar line; people wanting to get away from the noise and crowded conditions along the trolley lines used the automobile to further insulate themselves. This recalls Meyer's suggestion that an inversion of Hoyt's model might best apply in the automobile era (Meyer, 2000). While Green and Monier are helpful in their advocacy of aerial photography as a tool in understanding the urban environment, they might be just as important in this study as a reflection of social attitudes in the midst of the automobile era.

Adams proposes another model that differs in several ways from the classic economic models of Burgess, Hoyt and Harris and Ullman. The variables studied are extended to measures of the built environment. Adams $(1970,62)$ writes "a better understanding of urban spatial structures cannot ignore the age and density composition of urban residential areas." Cities of the American Midwest are again the object of study, so topography has limited influence and is completely ignored by Adams.

Adams' model, illustrated in Figure 2, is expressly temporal, relating periods of urban growth to transportation epochs. The earliest urban form Adams considers is a product of the Walking-Horsecar era, which Adams describes as pre-1850 to the late 1880s. The intermixed, tightly compact city of the pedestrian era exhibited little spatial growth; not until the Electric Streetcar era, which followed and lasted until approximately 1920 , was significant expansion possible. This technology, first implemented in Richmond, Virginia in 1888 (Muller, 1981), decreased both the cost and the time involved in commuting, opening peripheral areas to a much larger 


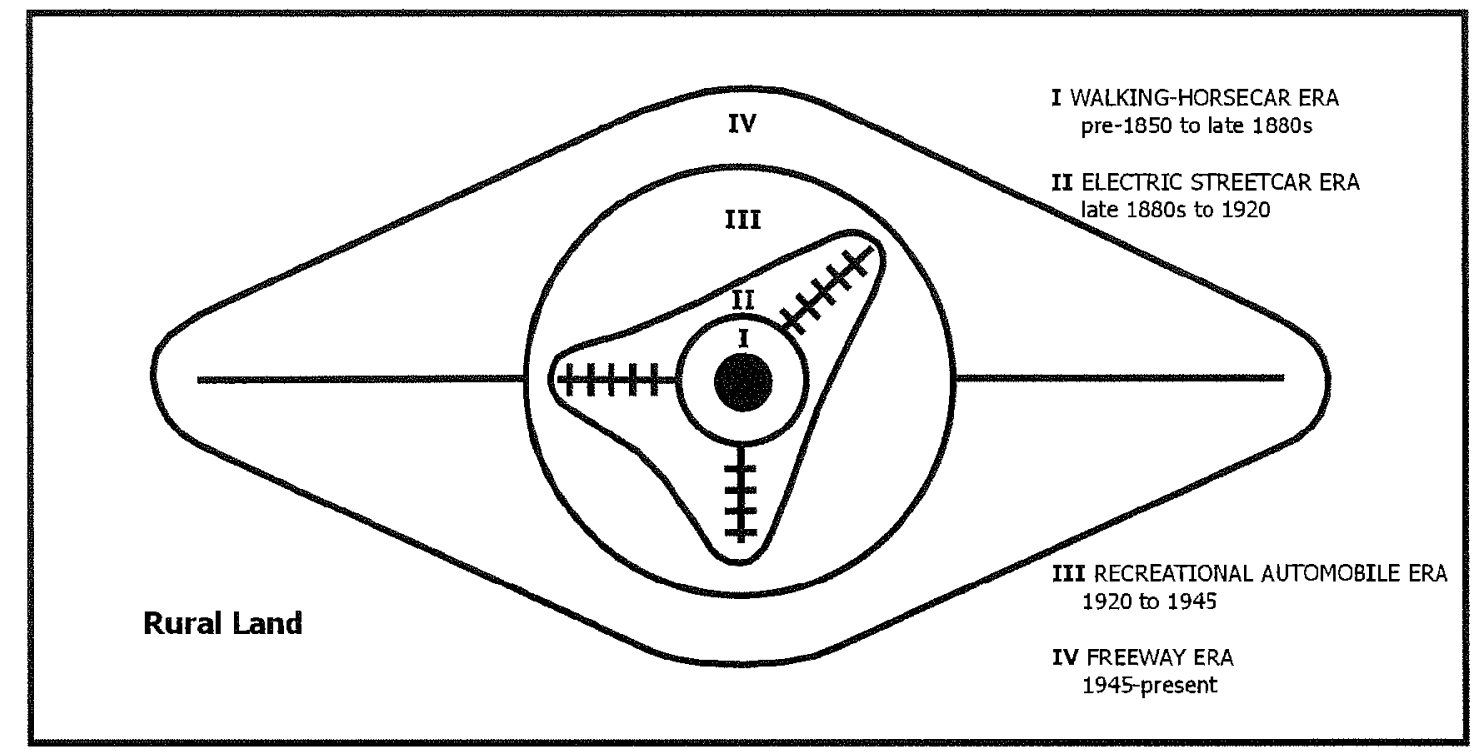

Figure 2: 1970 Adams Model

Adams' model suggests that the locations of built areas of an American city are a result of transportation. Eras associated with a particular transportation mode alternate between those that have no directional element, such as pedestrian travel and early automobile use, and those that do, such as trolleys and the automobile after the construction of freeways. Unlike the classic urban models, change over time is an integral part of this depiction of urban form. (Adapted from Adams, 1970) 
proportion of the populace. The Recreational Automobile Era (1920-1945) began with the mass adoption of the automobile, made possible again by technical advances that made ownership affordable to the middle classes.

Borchert (1967) had earlier identified 1920 as the time of transition from the Steel-Rail Epoch to the Auto-Air-Amenity Epoch, though he did not recognize the different nature of post-WWII urban growth. Adams did; once the car became thoroughly ingrained into American culture, the post-WWII Freeway era (1945Present) put its stamp on urban development. The temporal extent of the present study generally coincides with the transition from Adams' Electric Streetcar Era to the Recreational Automobile Era.

Adams tests his model through the use of four transects drawn across the city of Minneapolis. Two transects extend outward from the center; two are perpendicular to a line extended out from the center, laterally crossing a transportation route. Adams detects "expected distortions from concentric growth patterns" (Adams, 1970, 56), but examines only the age of housing. Differences in the character of the growth, such as density, are not considered.

An interesting aspect of Adam's model is the alternation between axial and central growth, to use Hoyt's terminology. Adams distinguishes between "movement surfaces" and "movement networks" (Adams, 1970, 46), assigning the first and third transport eras to the former, the second and fourth to the latter. The subject of this thesis is the character of the transition from the streetcar, a movement network, to the automobile, a movement surface. 


\section{$\underline{\text { New Urbanism }}$}

Proponents and practitioners of certain current urban planning theories, collectively known as New Urbanism, often look to pre-automobile urban form as a model for their developments, hoping to reproduce earlier travel behavior by replicating the land use patterns that accompanied them. Foremost among these ideas are Traditional Neighborhood Development (TND), sometimes referred to as Neotraditional Development, and Transit Oriented Development (TOD). As architects, planners and developers, the New Urbanists' emphasis is on the built environment, since that is the variable they control. The hypothesis of this study, that a change in transportation technology led to a change in land use patterns, is therefore reversed.

Banai $(1998,171)$ draws parallels between Burgess' concentric rings and design concepts of both TOD and TND, with their "similar rings of residential areas." Similarly, Hoyt's emphasis on the role of transportation lines is considered in relation to TOD elements, and "the spatial distribution of TODs suggests the notion of polycentricity as argued by Harris and Ullman in the context of the multiple nuclei theory of urban growth" (Banai, 1998, 173). Much like Green and Monier, Banai feels comfortable making the leap between socioeconomic measures of neighborhood status and physical aspects of built form.

TND, as practiced by planners and architects such as Andres Duany, consciously mimics urban neighborhoods as they existed before the sprawl associated with the automobile era. New Urbanism seeks to find what "pattern of development is 
the most environmentally sensitive, socially responsible, and economically sustainable" (Duany et al., 2000, 255), and finds it in the "historic model - the traditional neighborhood - adapted as needed to serve the needs of modern man." A highly connected grid street pattern is among the design elements advocated by Duany.

Traditionally the use of curvilinear streets and cul-de-sacs was confined to those areas where topography made them necessary; placing such features on flat ground "makes about as much sense as driving off-road vehicles around the city" (Duany et al., 2000, 34). Duany includes a checklist for TND consciously echoing elements of Clarence Perry's neighborhood unit concept, first introduced in the 1920s. The similarities are clearly seen in Figure 3.

Transit Oriented Development, Peter Calthorpe's contribution to New Urbanism, ties similar ideas within a regional framework by offering neighborhoods designed along transit routes. The outlook is on a larger scale, ignoring architectural detailing, and concerned with how the neighborhood fits into a larger urban system serviced by rail or bus.

Calthorpe $(1993,56)$ offers several recipes for TOD, described as a "community within an average 2,000-foot distance of a transit stop." For residential area TODs, several designs for which are illustrated in Figure 4, Calthorpe proposes higher densities of dwelling units in proximity to the transit line (Calthorpe, 1993), suggesting that these densities are needed to support transit, implicitly supporting the theory that such land use patterns will affect travel behavior. 


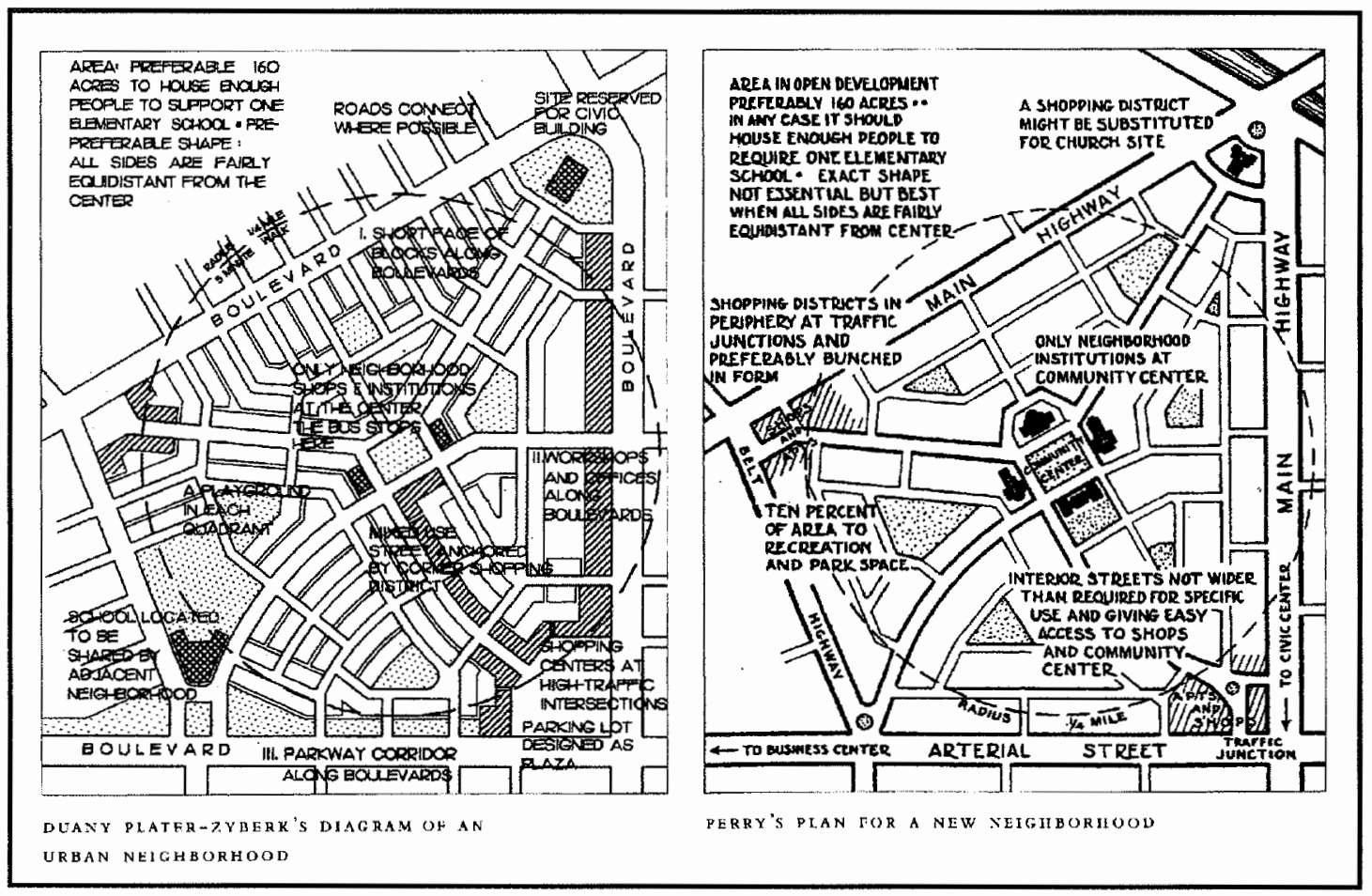

Figure 3: Clarence Perry and Andres Duany Neighborhood Designs Duany's adherence to Perry's neighborhood design includes the same total area and general shape, and the central placement of institutions. While Perry's design is bordered at the top by a "main highway," however, Duany's includes the stipulation that "roads connect wherever possible, and is much more integrated into its overall surroundings. The lower left hand corner of Duany's design includes a school "shared by adjacent neighborhood." (Congress for the New Urbanism, 2000) 


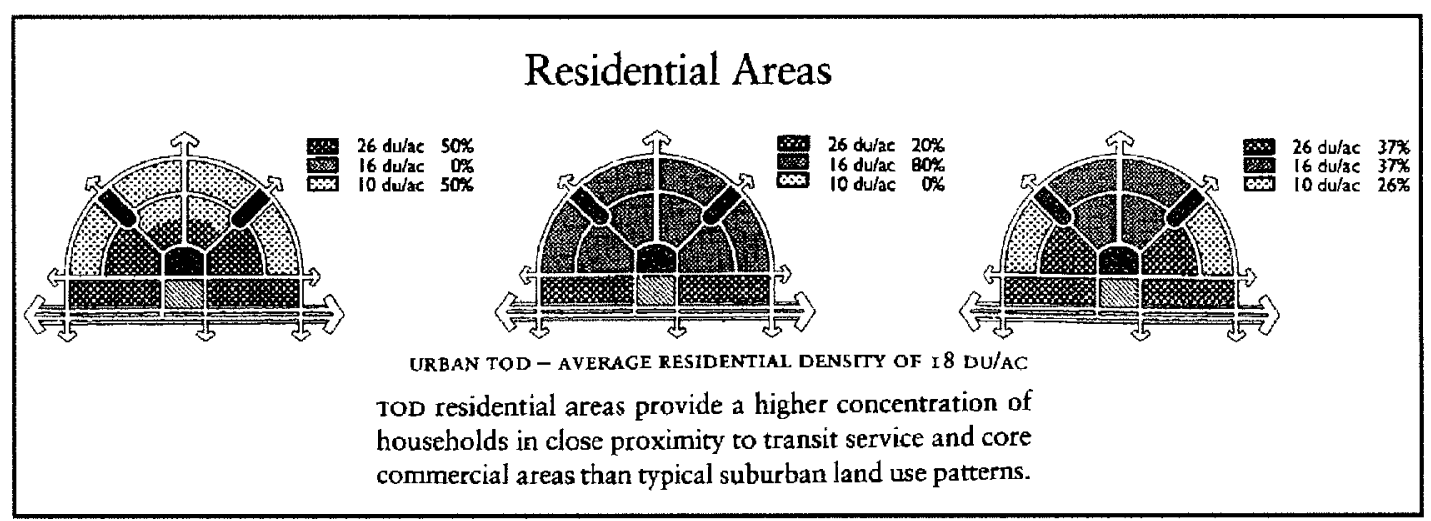

Figure 4: Calthorpe's Residential TOD Designs

The horizontal arrows along the bottom represent major transit lines, with secondary roads extending out from the core, which consists of a commercial area and transit stop. Housing densities, expressed as $\mathrm{du} / \mathrm{ac}$, for "dwelling units per acre," tend to be higher near the core, and the total residential area is clustered within a 2,000 foot radius, "representing a 10-minute walking distance." (Calthorpe, 1993) 
Duany and Calthorpe are architects, not scientists, and feel no apparent need to justify their ideas other than that they believe them to be true. Their concepts and presentation appeal to the emotions; both include "the American Dream" in the subtitles of their books (Calthorpe 1993, Duany 2000). Boarnet and Crane (2001) are among those who have attempted quantitative study of the link between land use and travel behavior, and found the connection dubious. Design that facilitates short walking trips could just as easily increase the number of automobile trips instead.

For the purposes of this study, it is unimportant whether the claims of the new urbanists are correct. What is important is their conception of the historical development of suburban neighborhoods, in essence extending ideas contained within the urban models of Burgess, Hoyt, and Harris and Ullman to include variables such as housing density, street network connectivity and land use mix. Studying the evolution of suburban land use has value even to those who "dislike this environment... (they) should study its form and pattern to understand the forces that are shaping it and to be able to improve it" (Southworth and Owens, 1993, 271).

Street networks, their characteristics and historical development, are the subject of the writings of Michael Southworth. Southworth's work entails longitudinal studies of street networks in urban fringe areas (Southworth and Owens, 1993), as shown in Figure 5, as well as comparative analysis of traditional streetcar suburbs and New Urbanist developments (Southworth and Ben-Joseph, 1997), illustrated in Figure 6. Southworth considers such variables as total length of streets, the number of blocks, and the number of intersections. The highly connected and dense grids of the 


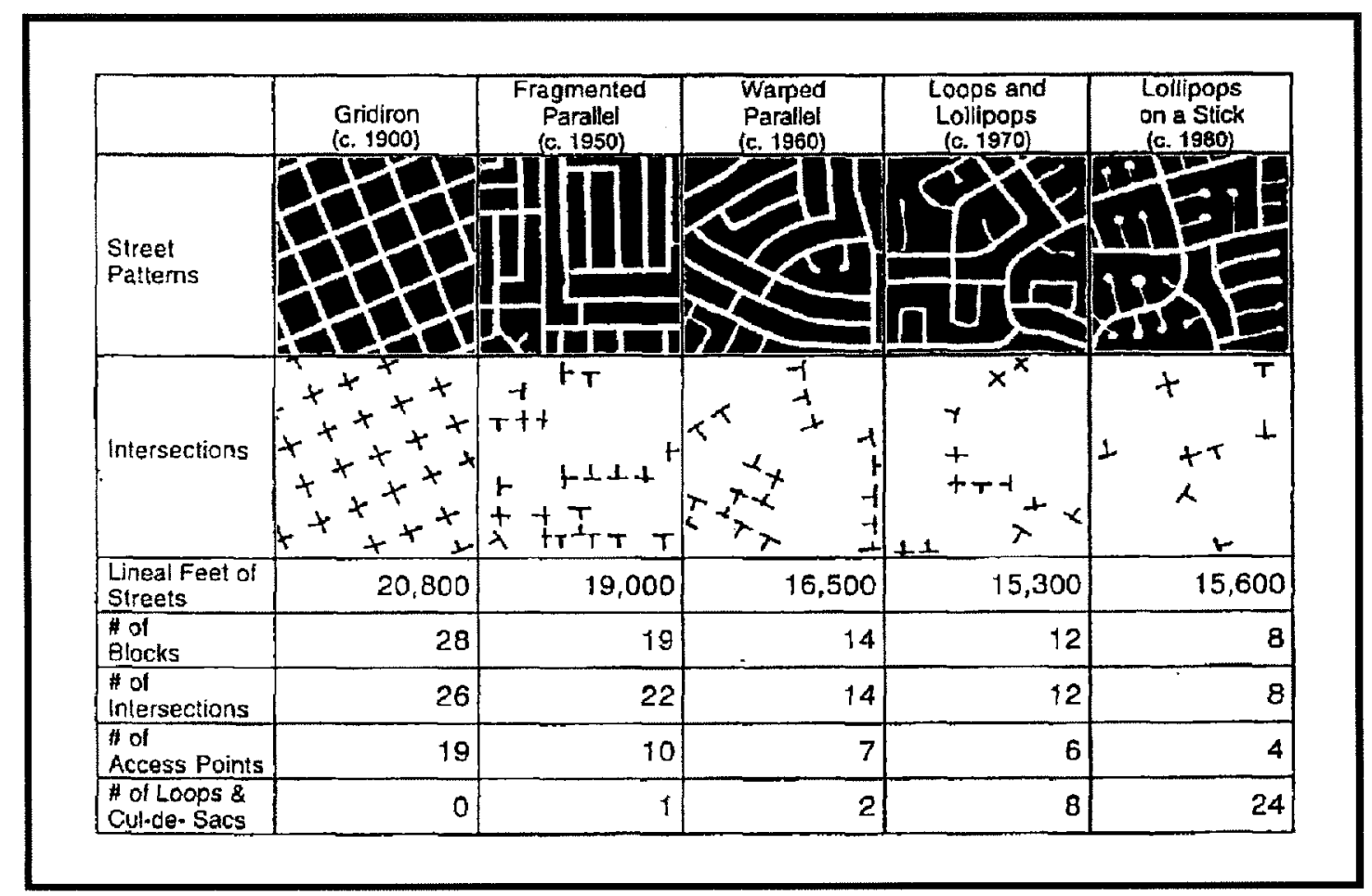

Figure 5: Southworth's Historic Analysis of Street Networks Southworth traces the development of typical street patterns from the streetcar suburb to full-blown automobile development. Note the distinction between four-way and three-way intersections in the drawings. Each area shown covers 2000 square feet. (Southworth and Ben-Joseph, 1997) 


\begin{tabular}{|l|l|l|l|}
\hline $\begin{array}{l}\text { Street } \\
\text { Patterns }\end{array}$ & \multicolumn{1}{|c|}{ KLMWOOD } \\
\hline
\end{tabular}

Figure 6: Southworth's Comparison of Traditional and New Urbanist Street Networks

The second focus of Southworth's research is the comparison of traditional streetcar suburb street networks with New Urbanist street designs. Notice that the number of intersections in New Urbanist street plans is equal to or exceeds the number of intersections in the traditional neighborhood, but that these are not weighted based on whether they are four-way or three-way intersections, despite that distinction having been made when counting them. (Southworth and Ben-Joseph, 1997) 
streetcar suburb, when people generally walked from their homes to the streetcar lines, evolve into the looser structures of "fragmented parallel" and "warped parallel" before eventually displaying the disconnected loops and cul-de-sacs associated with automobile development, where the longest walk one takes it to one's own driveway or garage (Southworth and Ben-Joseph, 1997).

While the classic connectivity measures developed by Kansky (1963) to compare the transportation networks of developed and undeveloped nations tend to be abstract and unitless, Southworth's measures are counted within 2000 foot grid cells, covering areas of approximately 100 acres. At the neighborhood scale, connectivity measures that include some consideration of the density of intersections are more meaningful.

This emphasis on the highly connected grid sets the New Urbanists apart from some of their earlier inspirations. Christopher Alexander, for example, is no fan of the four-way intersection, considering them dangerous in comparison to three-way " $\mathrm{T}$ " intersections (Alexander et al., 1977). Furthermore, a lack of connectivity to surrounding areas enhanced a neighborhood's sense of identity, according to Alexander.

"From observations of neighborhoods that succeed in being well-defined, both physically and in the minds of the townspeople" Alexander $(1977,88)$ writes, "we have learned that the single most important feature of a neighborhood's boundary is restricted access into the neighborhood: neighborhoods that are successfully defined have few paths and roads leading into them." New Urbanism does represent a break 
from previous thinking and methods in actually looking backward to earlier urban forms, increasing the relevance of historic studies in today's planning debates.

Krizek applies aerial photography to the study of modern neighborhoods, using photographs to measure variables of the built environment from the New Urbanist perspective of assessing neighborhood accessibility (NA), in an effort ultimately to determine the effect such neighborhood characteristics have on travel behavior. Combining measurements of street patterns, density and land use mix, Krizek creates an index measure of NA. These measures are determined within grid cells of 150 square meters, as seen in Figure 7, resulting in grids covering about one sixteenth of the area Southworth considers in his analyses; Krizek uses a technique of averaging in the values of adjoining cells "over a walking distance of one-quarter mile" (Krizek, under review, 11). This method therefore actually assigns values to the cells based on a larger area. 150 meters is hardly enough to capture more than a few street intersections, and seems much too small a grid cell size in itself.

Density is the most straightforward variable to operationalize, "more commonly used than any other urban form measure" (Krizek, forthcoming, 5), and is calculated as the number of housing units for some unit area, just as Calthorpe proposed in his TOD designs, similar as well to Green and Monier's methodology. To measure street patterns, Krizek examines both intersection type and intersection density. Intersection type distinguishes between ' $\mathrm{X}$,' or four-way intersections, and three-way ' $\mathrm{T}$ ' intersections. Krizek (forthcoming, 9) considers street network density an equally important and overlooked factor, since "gridded streets laid out in 


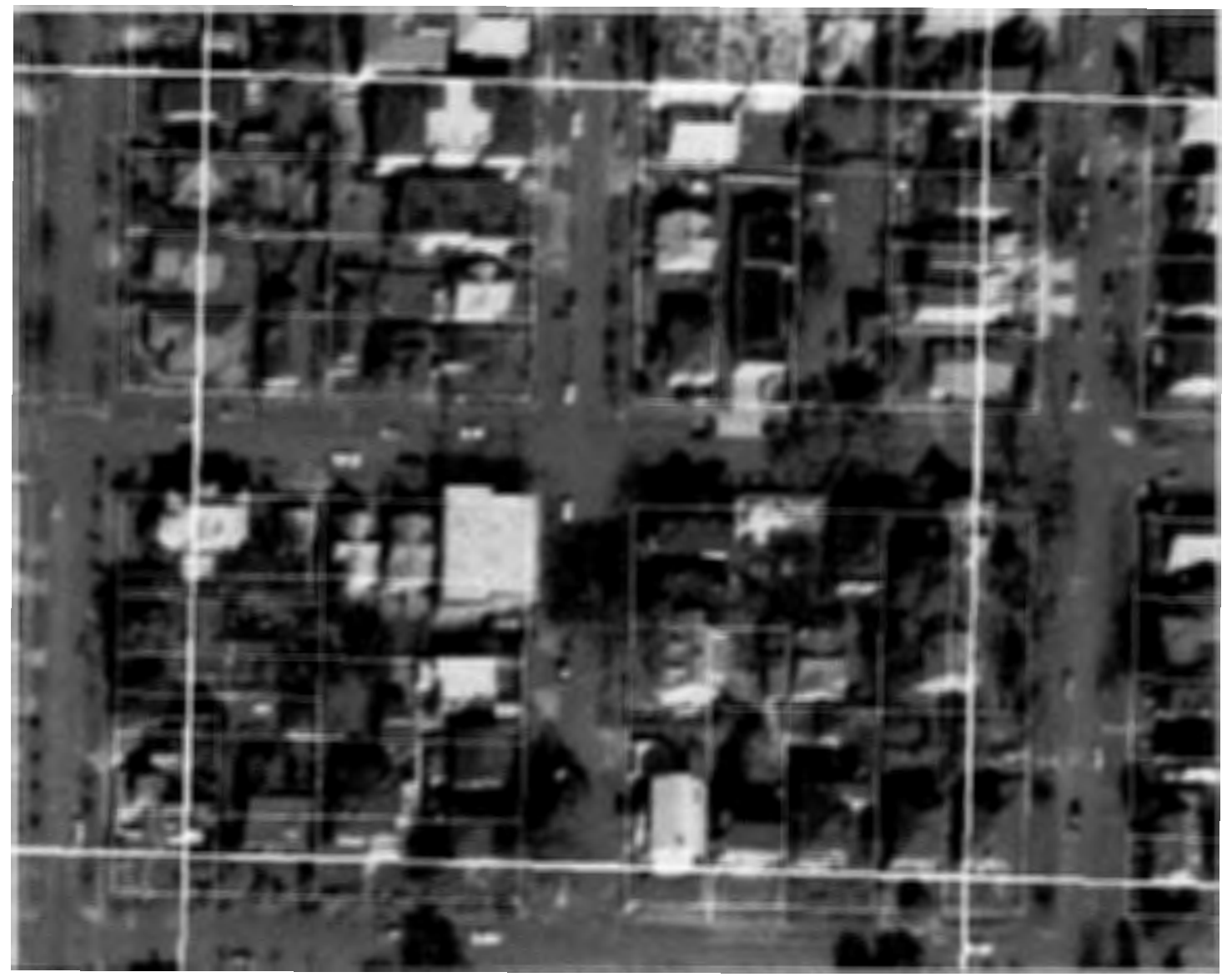

Figure 7: Krizek's Aerial Photography with 150 Meter Grid Cell Krizek's grid cells seem too small for useful analysis; this cell, in a highly connected, gridded street system, contains only one intersection. He uses a system of assigning values to particular cells that incorporate the values of surrounding cells within a distance of one-quarter mile. Notice also that Krizek has included parcel data in this figure. (Krizek, Forthcoming) 
superblocks with intersections every 1,000 or so feet often times do little to promote pedestrian travel; they may actually foster free-flow automobility."

Portland today is an adherent to several New Urbanist principles (Marshall, 2000). With an urban growth boundary and a regional government, METRO, in place since the 1970s, the emphasis has been on planning to control sprawl and encourage infill development. Calthorpe credits the land use watchdog group 1000 Friends of Oregon for sponsoring a study (conducted by Calthorpe) entitled LUTRAQ (Land Use-Transportation-Air Quality), beginning in 1991, in response to a planned highway to Washington County, a suburban area to the west of downtown Portland. 1000 Friends "ultimately succeeded in helping to replace the bypass freeway with a new light-rail system and the sprawl with a new type of development call Transit Oriented Development" (Calthorpe and Fulton, 2001, 109). Calthorpe is not entirely accurate in this statement; an east-side light rail line had been in place for several years. Recently, a downtown streetcar line began running between Portland State University and the gentrified Pearl District, with plans for expansion. 


\section{Chapter 3: Study Area}

\section{Spatial Extent: Portland's Eastside}

Portland is a city divided by the Willamette River, and the two halves are different historically, topographically and socially. The earliest settlement area and present day central business district occupy a physically confined area between the river and the West Hills. East Portland existed as a separate entity until a merger in 1891 , but even then the city, with a population of 62,000 , occupied a mere 26 square miles (MacColl, 1976). Access to the east side of the river was provided solely by ferry until the first bridge was built in 1887 , with several more soon following. The boom years following the 1905 Lewis and Clark Centennial Exposition, which attracted over 2,500,000 visitors (MacColl, 1976) roughly coincided with the initial period of construction of the electric streetcar lines, a vast improvement over the horse cars and steam trains that had constituted Portland's transit options to that point (Labbe, 1982).

Accepting the hypotheses of Burgess and Hoyt that topography and transportation are the determinants shaping urban growth, a cursory comparison of the two sides of the Willamette, seen in Figure 8, is enough to demonstrate which variable was more of a factor in each case. Portland also had a system of interurban lines reaching more remote areas such as Oregon City, Estacada and Troutdale, places that today remain separate and distinct from Portland. Since this paper concerns itself with changes within the urban area, only the city lines will be considered. 


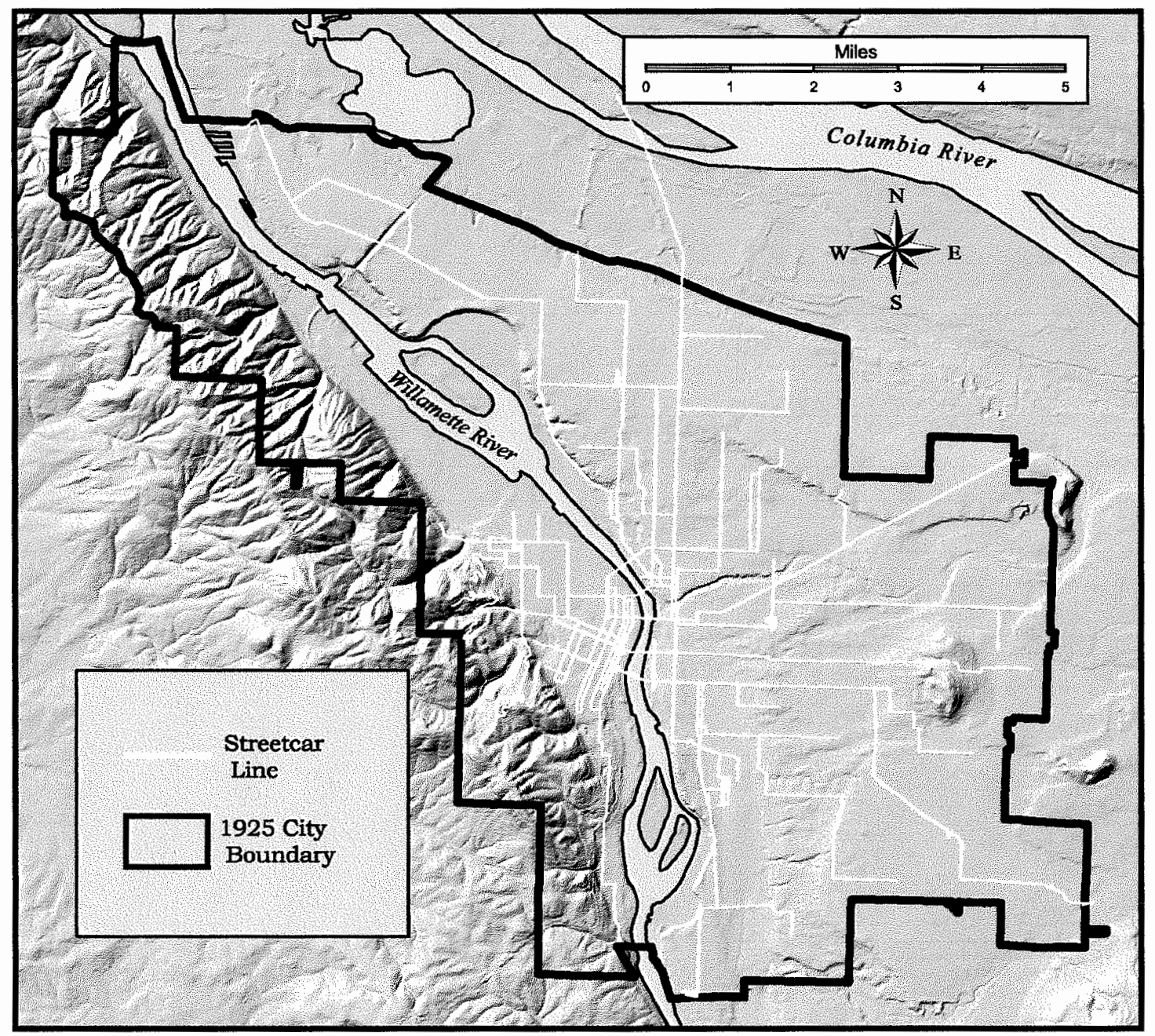

Figure 8: Portland's Topography and Extent of Streetcar Network The 1925 city boundary, from annexation data provided by the City of Portland Department of Planning, changed little throughout the study period. The correlation between that boundary and the extent of the streetcar network, from data provided by the City of Portland Department of Transportation, is immediately clear, as is the difference in topography on either side of the Willamette River. The shaded relief data is from Metro's RLIS (Regional Land Information System) data, and is current. The river boundary and configurations of Swan and Ross Islands were acquired from a 1927 land use zoning map. 
Portland's west side has only one area that can be considered a streetcar suburb distant from the city center, the John's Landing area south of downtown. Whether the topography impeded the construction of the streetcar lines, or if one accepts Burgess' "other model" and concludes that the topography rendered separation by distance unnecessary, it is visually apparent that the streetcar lines provided little opportunity for growth on the west side of the Willamette.

The east side is another matter. Topographic variation, though present, is minimal. The better residential areas did gravitate to the higher elevations, attracted by the views, while the "gently sloping valleys between the ridges provided ideal corridors for roads and trolley lines" (Department of Transportation, Federal Highway Administration and Oregon State Highway Division, 1973, 7). As a determinant of growth, however, topography was clearly less of a consideration.

The correlation between city boundary and the extent of the streetcar network, however, is obvious. As stated in the Environmental Impact Statement for I-80N (since renamed I-84), "By the 1920s all of Portland's eastside trolley lines extended to points about five miles from the city center, suggesting this was the effective limit of their service area. Even today (1973), the city limits still mark the terminus of these trolley lines" (Department of Transportation, Federal Highway Administration and Oregon State Highway Division, 1973, 5).

The opportunity for home ownership drew people across the river. While downtown remained the employment center, access to the plentiful, and therefore 
relatively inexpensive, land on the east side allowed the rising middle class to purchase property. Many of the streetcar lines were initially constructed by land developers before being turned over to utility companies (Abbott, 1983). The resulting population shift is clearly seen in Figure 9. Writes Abbott $(1983,55)$, "The contrast between east-side and west-side Portlanders was clear by 1910 . The eastsiders were property owners." For this reason, this study will limit itself to Portland's eastside, and consider that to be the extent of Portland's "streetcar suburbs."

One additional consideration limits the spatial extent included in the analysis for this study. An initial attempt at land use zoning utilizing the services of Charles Cheney, "an evangelist for a new direction in city planning," (Abbott, 1983, 71) had failed to win election in 1919; a more pragmatic plan influenced by the interests of local realtors did win passage in 1924 and remained in place, albeit with modifications, until 1959 (MacColl, 1979). Portland was divided into four types of land use zones, as illustrated in the map in Figure 10. Zone 1 roughly translates into Single Family Residential, and covered approximately $18 \%$ of the area within city limits. Zone 2, Multi-Family Residential, comprised $41 \%$ of the city. Zone 3 , the Commercial/Light Industrial area, also allowed residential uses and covered $26 \%$ of the city. Finally, the unrestricted Zone 4 was limited to $10 \%$. These numbers are offered by MacColl (1979) and do not add up to 100\%. Abbott (1983) uses slightly different figures. One interesting aspect of these zoning regulations is the inclusion of all areas adjacent (within about half a city block) to streetcar lines in Zone 3, a 


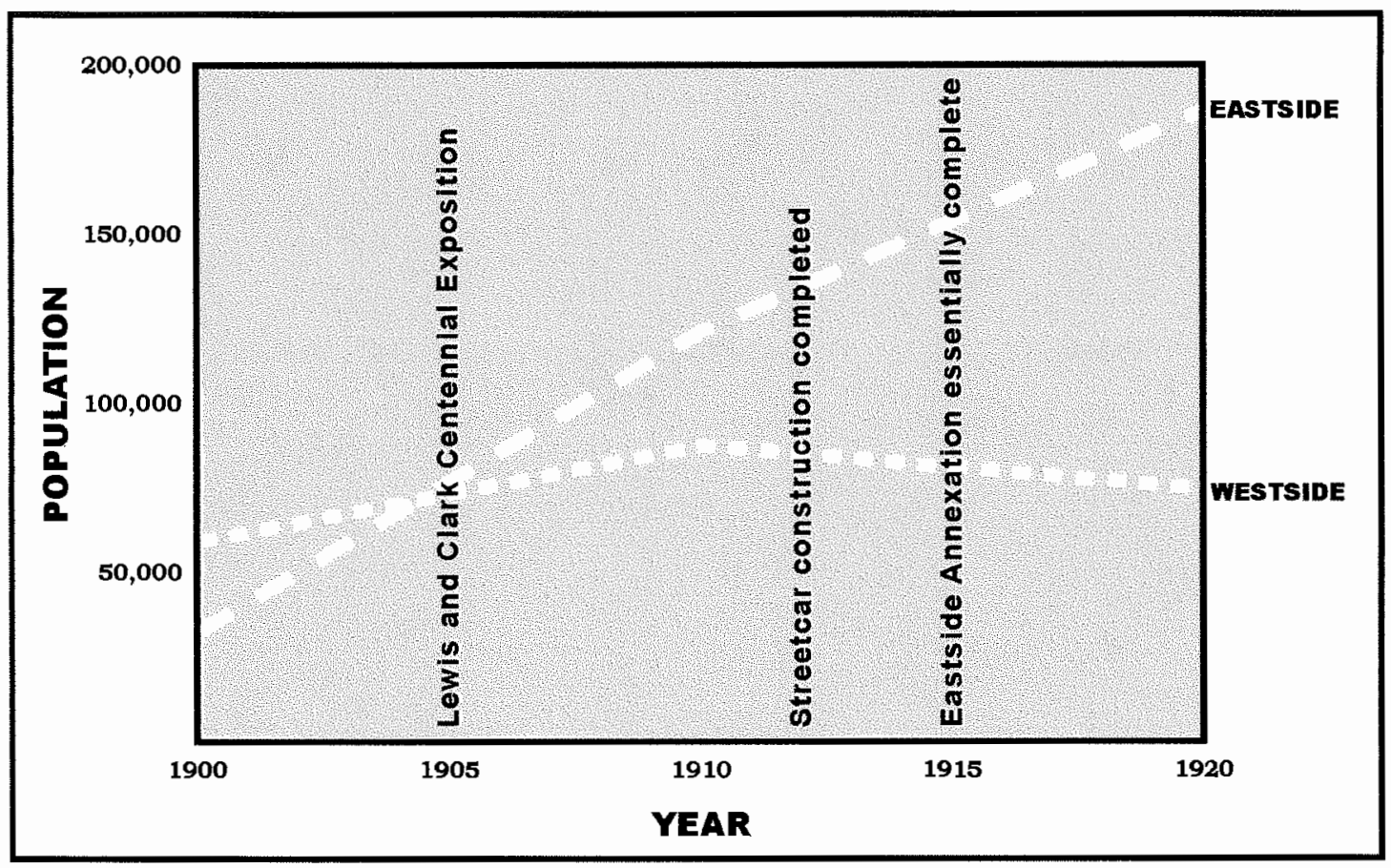

Figure 9: Portland's Population Trends 1900-1920

While annexation of existing neighborhoods explains some of the increase in eastside population, that annexation slowed considerably after 1915. Westside population actually decreased between 1910 and 1920, the heyday of the streetcar. (Drawn by the Author from data in Abbott, 1983) 


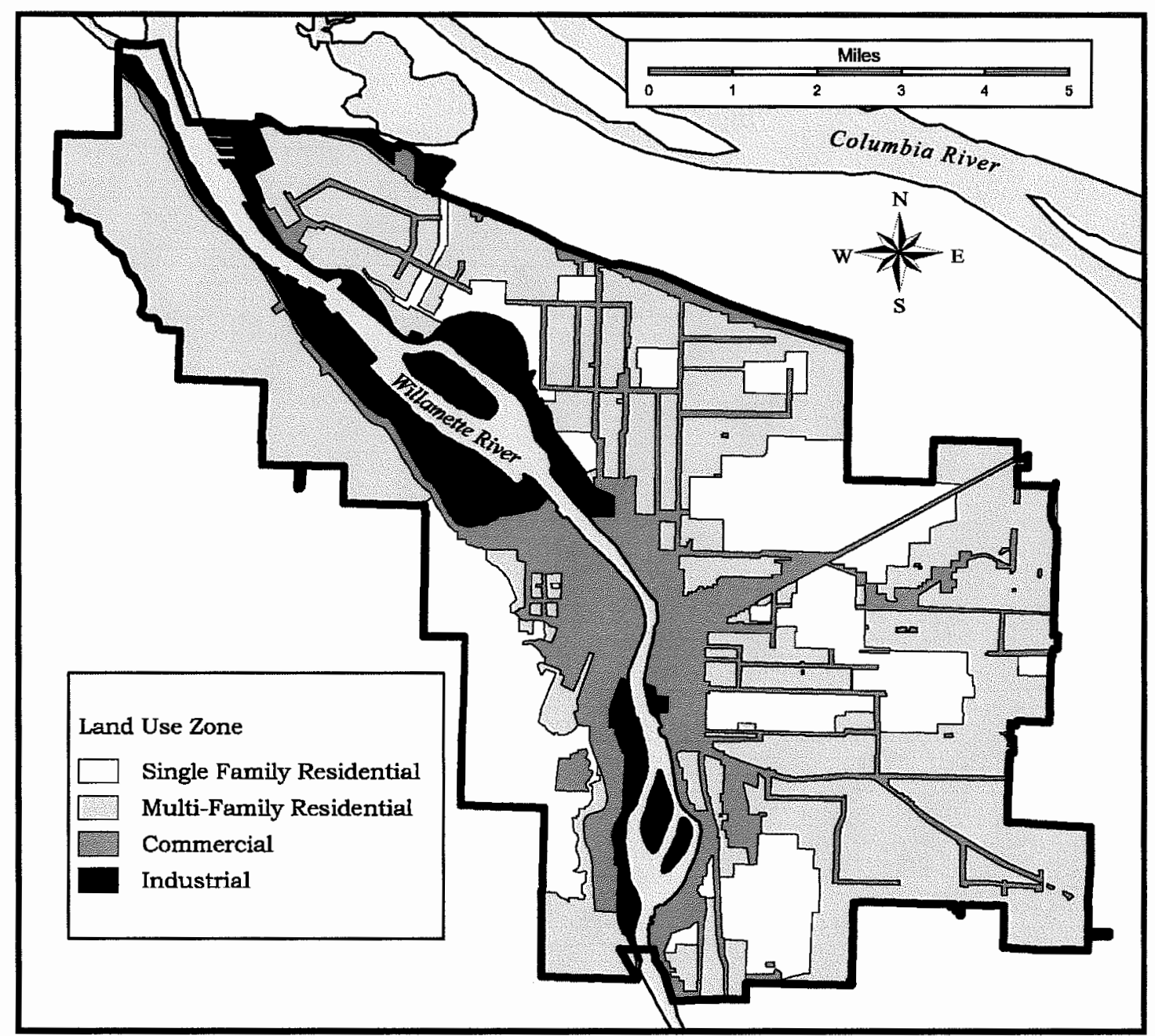

Figure 10: 1927 Portland Land Use Zoning

These descriptions of land use zones are rough equivalents of modern zoning practices. Higher uses were allowed in a particular zone; for example, the commercial zone included residences, and the industrial zone was unrestricted. The source of data for this map is a 1927 City Planning Commission Map in the collection of the Oregon Historical Society. 
precursor of sorts to the New Urbanist idea of mixed use in conjunction with transit. Because this study is interested in the dynamics of residential urban growth, it is confined to the extent possible within Zones 1 and 2. Figure 10 shows the overwhelmingly residential nature of the eastside and the effective restriction of westside residences to the hills behind the central business district. The large area included in zone two, in the northwest corner of the city, was never developed; this area became Forest Park in 1945, the "largest semi-wilderness park within a city's limits in the continental United States" (MacColl, 1979, 115).

Temporal Extent: $1925-1945$

In 1925 Portland's east side represented a streetcar suburb; in 1945, land use patterns in this same area had been altered by widespread use of the automobile. Therefore, the years 1925-1945 demonstrate the transition between these two types of urban form. In this section of this paper, I will make the historical case for this argument by discussing how transportation use changed during this period.

Figure 11 is adapted from Figure 4 in the I-80N (now called I-84) Environmental Impact Statement (EIS). The original figure is entitled "Relative Usage of Transportation Modes in Portland," and has several flaws. Streetcar and bus data are classified together, or the drop in usage after 1920 would be still more precipitous. If streetcar usage had been shown alone, that line on the graph would disappear in 1950, when the last of the original streetcars operated. Inclusion of earlier transit options cause this grouped transportation mode to show up in the 


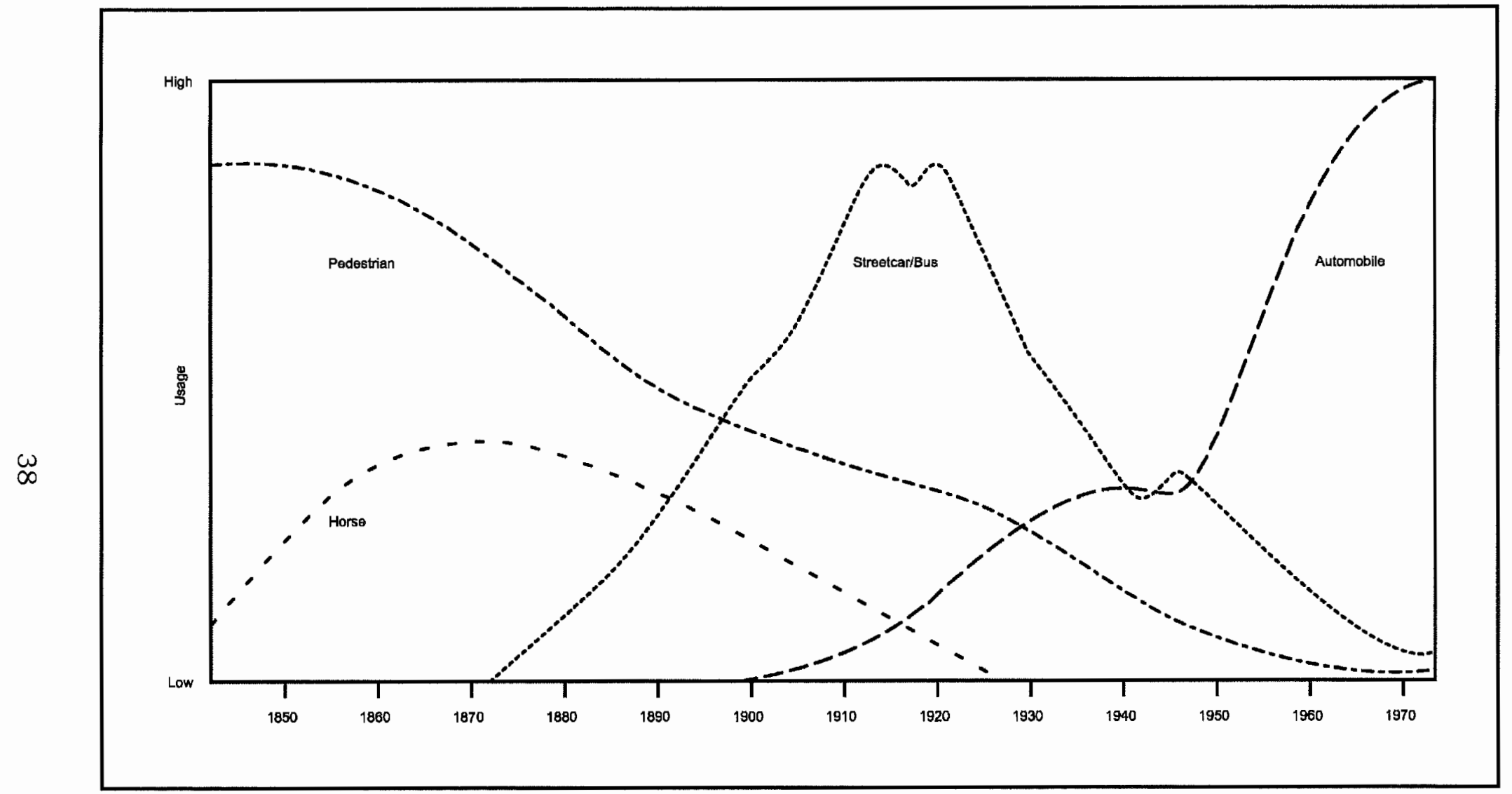

Figure 11: Portland's Transportation Epochs

This graphic vividly displays Portland's major transportation epochs. The period considered in this study extends from shortly after the peak of streetcar usage to a time of rapidly increasing automobile use. (Adapted from Department of Transportation Federal Highway Administration and Oregon State Highway Division I -80N Environmental Impact Statement Administrative Action. 1973) 
graphic before the actual operation of the electric streetcar lines. The measure along the y-axis, "usage," is not defined

What this figure does provide is a powerful visual representation of Portland's transportation epochs, slightly different from those delineated by Adams, reflecting Portland's youth relative to the Midwestern cities included in Adams' study. The period 1925-1945 begins shortly after the peak of streetcar usage, and ends when automobile usage finally catches up, never to look back. There is some fluctuation between public transportation and automobile usage during the 1940s, a result of gas and tire rationing during World War II (Bianco, 1994).

Bianco (1994) chronicles the rise and fall of the streetcar in Portland in great detail. Even while being constructed, the handwriting was on the wall for the streetcar system. The "growing distress experienced over the period between about 1905 and 1925 " nevertheless coincided with increased usage; by 1923 "it was apparent that ridership and revenues were on a steady decline" (Bianco, 1994, 253), in part because of competition from the automobile. Bianco (1994) identifies the apex of the streetcar as the years from 1918 to 1920 . Figure 12 is taken from her dissertation with only slight modification.

The EIS for I-80N was less finely tuned in its definition, and defines the high point of public transportation in Portland as between the years 1900-1930 (Department of Transportation Federal Highway Administration and Oregon State Highway Division, 1973). Subsequently, "after the introduction of the automobile to the 


\section{Street Car Ridership}

1905 to 1924
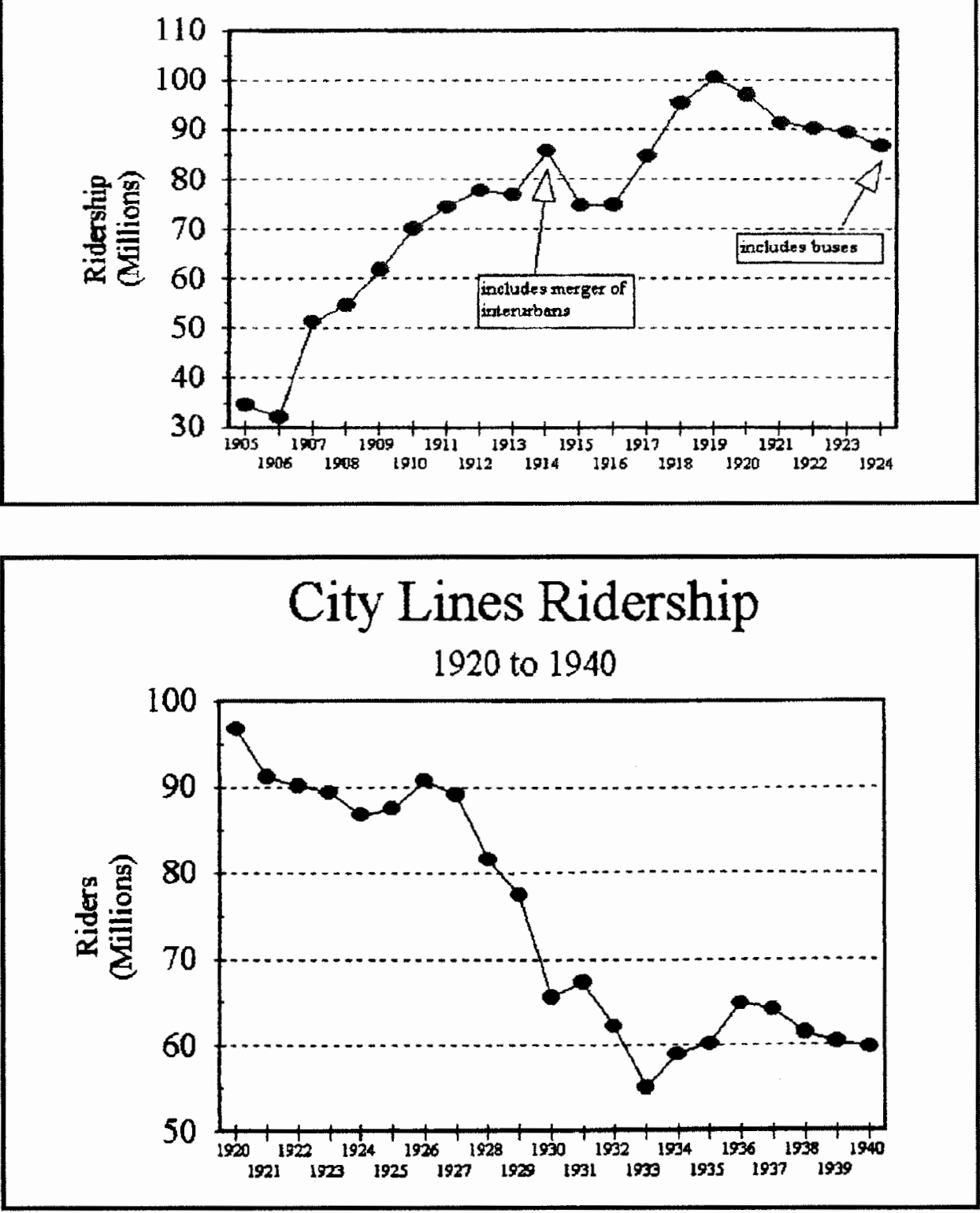

Figure 12: Portland's Streetcar Usage

As is often the case with historical studies, the data in these figures appear to be collected from several sources, hence the mixing of modes in the upper graph. The overall trend, however, is clear. Streetcar usage shows an upward trend until about 1920, then plummets. (Adapted from Bianco, 1994) 
Portland transportation scene, the various forms of public transportation began to diminish in importance" (Department of Transportation Federal Highway Administration and Oregon State Highway Division, 1973, 6). At the same time automobile ownership and use were on the increase. Abbott $(1983,93)$ writes:

Everybody in Portland wanted to buy an automobile in the 1920s...In the best years in the middle of the decade, Portland's eighty automobile agencies sold forty cars a day. Multnomah County registered fewer then 10,000 motor vehicles in $1916,36,000$ in 1920 , and over 90,000 at the time of the great crash... When the majority of households had access to their own automobile, it was not surprising that streetcar use began to drop after 1926.

Concurrent changes in the character of development were also noted:

Along with the demise of the city's early public transit system, the auto also introduced new patterns of urban growth not tied to the fixed-route systems. The flexible automobile allowed suburban development in areas not served by streetcars or interurban lines. Development became less dense, less coordinated and uncontrolled. (Department of Transportation Federal Highway Administration and Oregon State Highway Division, 1973, 6)

Abbott (1983, 95-96) puts it this way:

Streetcar transportation had established a clear hierarchy of land uses based on differences in accessibility... Individual transit lines formed spokes that were bordered with neighborhood businesses. Within the residential wedges between the spokes, the real estate market placed a premium on convenience to public transit. The auto, in contrast, was a great equalizer of space that tended to make cities more homogeneous. Fords and Chevrolets upset the neat structure by dramatically increasing the accessibility of land off the trolley lines... 
Bianco identifies the beginning of the decline of the streetcar era as the year 1920; Abbott uses the date 1926, and the I-80N EIS suggests that 1930 marks the end of Portland's best years for public transportation.

The aerial photo in Figure 13 portrays an area of close-in southeast Portland, approximately three to four miles from downtown, in 1925. The streetcar line can be seen entering the photograph on the left, then turning east (the photograph has north orientation) and proceeding along the bottom of the photograph, through the relatively dense building along Gladstone Street. Powell Boulevard to the north passes through an undeveloped area, including some thick wooded growth.

Today, Powell Boulevard is one the busiest streets on the east side, moving a large volume of automobile traffic. Along this stretch, between about $28^{\text {th }}$ and $34^{\text {th }}$ Avenues, Powell Boulevard is lined with a variety of automobile traffic oriented businesses, including fast food restaurants, inexpensive motels and convenience stores. The area around Gladstone retains its residential character, primarily single family but sprinkled with apartment buildings, mostly built in the 1950s and 1960s. The area between the two streets has filled in with apartment complexes of the same period.

This is visual evidence that the influence of the streetcar line on 1925 Portland land use patterns was strong. In inner southeast Portland, growth along the streetcar routes had by 1930 established a skeletal structure around which the area would become fully developed by 1950 (Department of Transportation Federal Highway Administration and Oregon State Highway Division, 1973). 


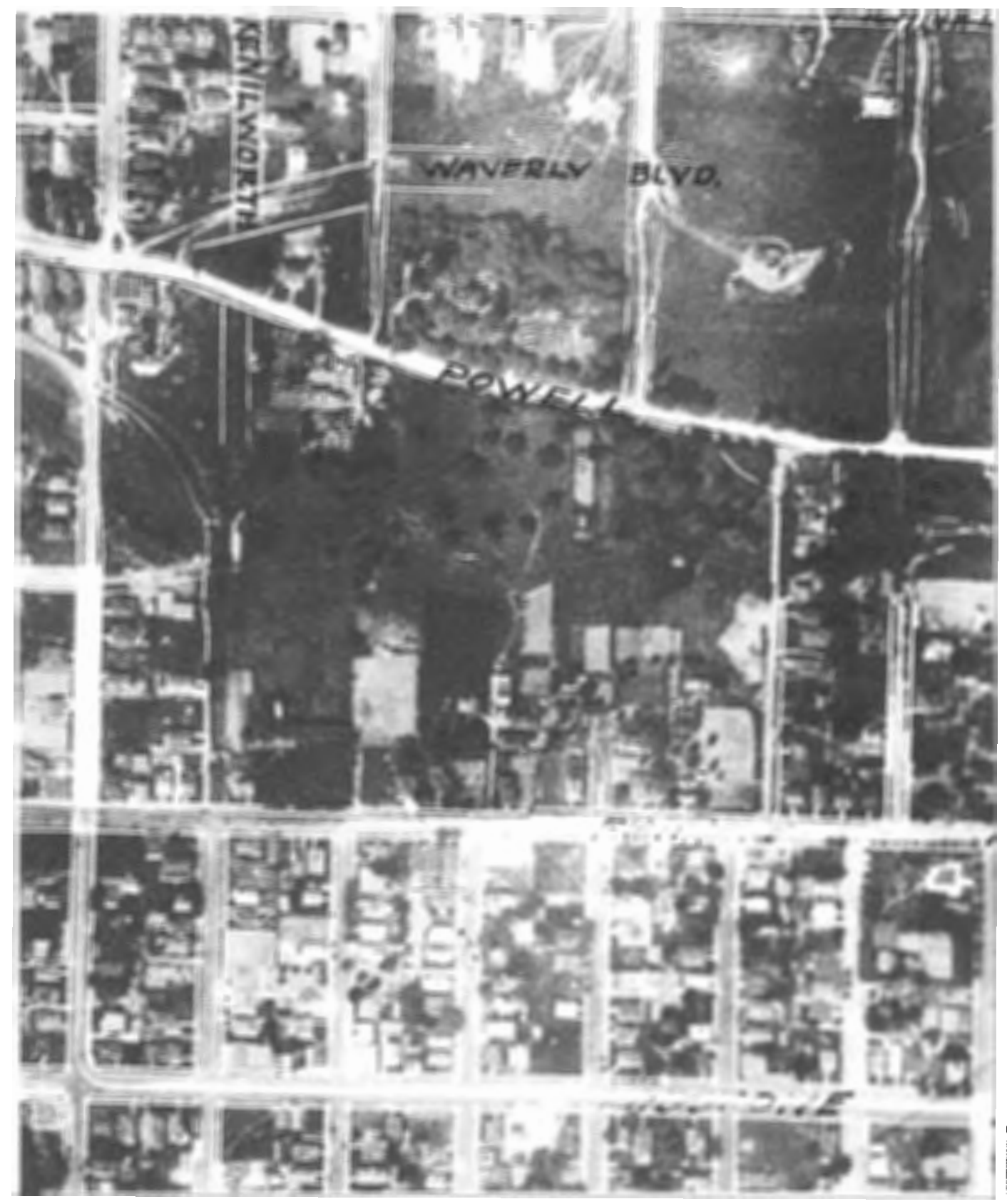

Figure 13: 1925 Aerial Photograph of Inner Southeast Area Note the rounded corners where the streetcar turned before passing through a relatively dense residential area, along the left and bottom edges of this image. Powell Boulevard (then called Powell Valley Road) had no streetcar and is surrounded by mostly vacant land. The cross streets range from about $28^{\text {th }}$ to $34^{\text {th }}$ Avenues. (Original photograph in the Collection of the Stanley Parr Archives and Records Center) 
Was transportation change alone in causing the changes in land use patterns described? An argument could be made that zoning regulations made a significant contribution. Zoning, after all, had been initially established in Portland in 1924, at the beginning of the period in question, and served to separate land uses directly. If one can no longer live and work in the same location, one must commute; if a streetcar doesn't connect the two places and the distance is too far to walk, an automobile would be essential. Marshall counters this argument. "Mixed use is a product of preautomobile transportation systems. Cars and arterial-style highways separate uses" (Marshall, 2000, 200). Transportation is the driving force, he argues; zoning just follows along. "The major transportation systems dictate the pattern and style of developments" (Marshall, 2000, 212).

The FHA, Hoyt's employer, codified many building practices, influenced by Perry and Clarence Stein, among others, and published several guidebooks throughout the 1930s (Southworth and Ben-Joseph, 1997). These guidelines suggested liberal setback distances, promoted cul-de-sacs, even discouraging "excessive planting for a more pleasing and unified effect along the street" (Southworth and Ben-Joseph, 1997, 85). Although not mandatory, using financial incentives the "federal government was able to exercise tremendous power through the simple act of making an offer that could not be refused" (Southworth and Ben-Joseph, 1997, 87). Still, all of this is ultimately in response to changes in transportation. Stein's Radburn development, a model for FHA guidelines, was designed with an understanding of the influence being exerted by the automobile. Wrote Stein, "The flood of motors had already made the 
gridiron street pattern...as obsolete as a fortified town wall" (Southworth and BenJoseph, 1997, 63).

FHA mortgage lending policies did allow the building boom of the 1920 s to continue, albeit to a lesser degree, during the Depression. Automobile ownership, however, never flagged. Motor vehicle registration rose by 4.5 million nationally between 1929 and 1945 (Jackson, 1985). Adds Jackson, "No other invention has altered urban form more than the internal combustion engine" (Jackson, 1985, 188). The car was the cause of the changes occurring during this period; other factors were ancillary. 


\section{Chapter 4: Data Collection}

\section{Source: Aerial Photography}

The data used in this study is gathered from historic black and white aerial photography of the Portland, Oregon area. Details concerning the acquisition and processing of this imagery are contained in Appendix A. The earliest available photographs date from the year 1925 and demonstrate the lack of a systematic approach to their acquisition; these were used in the creation of a large aerial photographic map. Photographs were mosaicked together in a manner that seems haphazard by today's standards, and later cut into seventy-eight sections each roughly twenty inches square. There is therefore no overlap, and no familiar radial pattern of distortion from the nadir of the image. A smaller index map, shown in Figure 14, indicates the location of the coverage areas for each photograph, identified by number. The three photographs directly over the downtown core area are missing. The rest are in reasonably good shape except for some abrasion along the edges, resulting in some loss of coverage. Despite the flaws, the existence of these images, created only twenty two years after the invention of the airplane, is remarkable. I was unable to determine whether these images were acquired using an airplane or some lighter-than-air craft; no telltale shadows are visible.

Later photography dates from 1936 and 1945. Systematic flight planning, including roughly parallel flight lines and overlapping coverage, were used in the acquisition of these photographs, indicating the advancement of methods used in the 


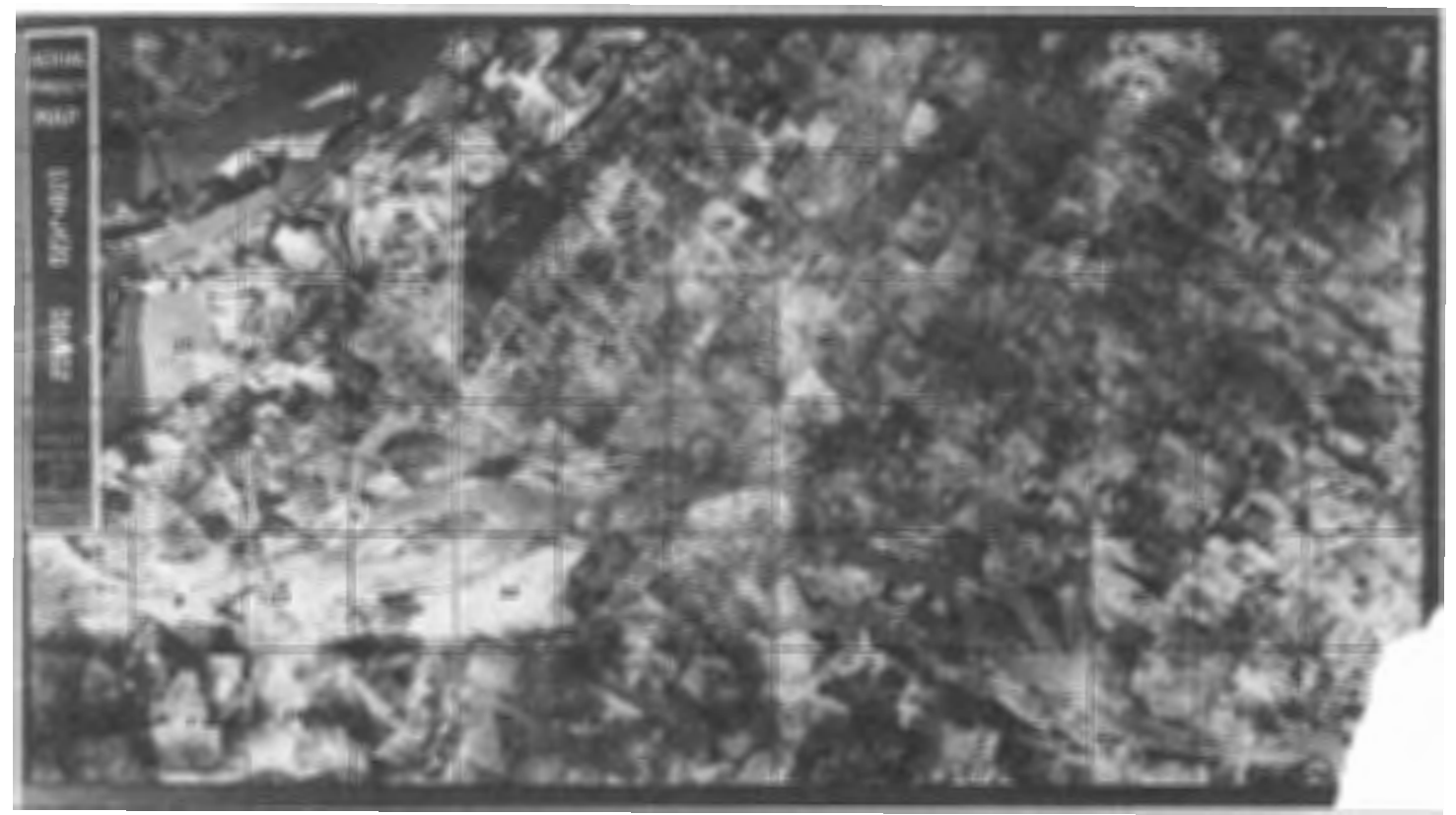

Figure 14: 1925 Aerial Photography Index This index has a Northeast orientation. Nearly complete coverage of the area within the 1925 city boundary is provided by this aerial photography, missing only a small section in the eastern section of the city. The three photographs over the downtown area are missing. (Original photograph in the Collection of the Stanley Parr Archives and Records Center) 
field of photogrammetry. The extent of the 1925 photography determined the number of photographs needed from the later years.

Once georeferenced and rectified to align in the same geographic space and eliminate distortion inherent in the photographic process, new digital images are created with pixel values resampled to a final ground resolution of two feet; that is, one pixel in the image covers two square feet on the ground. This resolution is easily sufficient for the types of measurements I needed to make.

Neighborhood Examples

Portland is formally divided into some 96 city-recognized neighborhoods. Individual neighborhoods provide a useful unit for observation of the changes over the time period of this study, as they display a certain level of internal coherence. An initial, non-analytical look at three of these neighborhoods - Alameda, Portsmouth and Woodstock - precedes a deeper examination. My intention in choosing these particular neighborhoods was to represent the spectrum of east side types, both geographically and socially. The map in Figure 15 shows the locations of these neighborhoods.

Alameda (Figures 16-18) is in the Northeast sector of the city, and occupies an elevated position on a ridge. This ridge is evident in the aerial photography through the deviations from a grid street pattern. Built "with curving street plans" that indicate that it was "intended for business and professional families" (Abbott, 1983, 55), Alameda was literally an exclusive area; if the $\$ 3,000$ minimum price on housing was not enough, the brochures stating "No people of undesirable colors and kinds" 


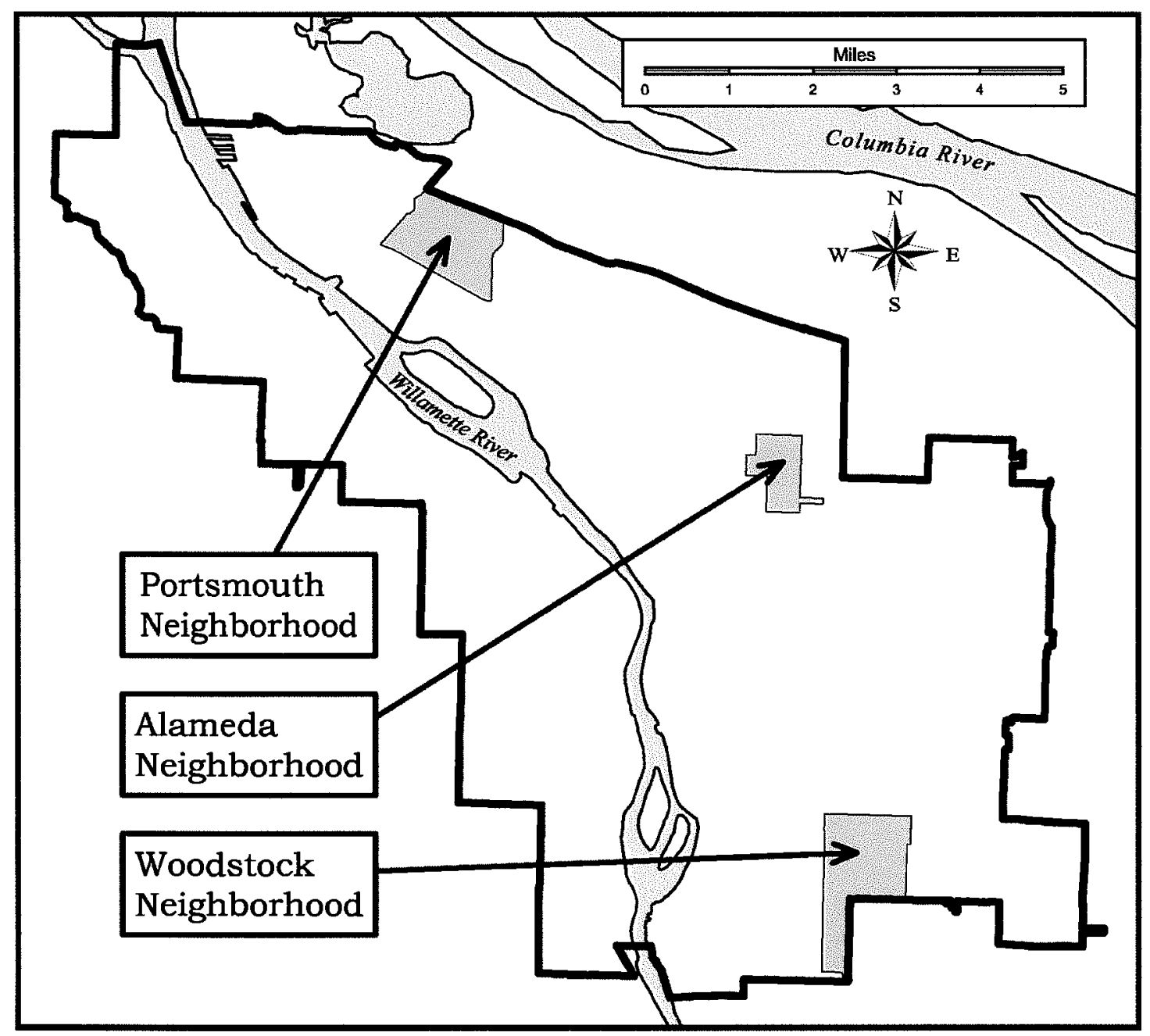

Figure 15: Locations of Aerial Photography Neighborhood Examples The locations of the neighborhoods shown in figures 16-24 are shown here in relation to the city as a whole. Although very different socially and geographically, similar changes took place in these neighborhoods as the streetcar was phased out and replaced by the automobile. 


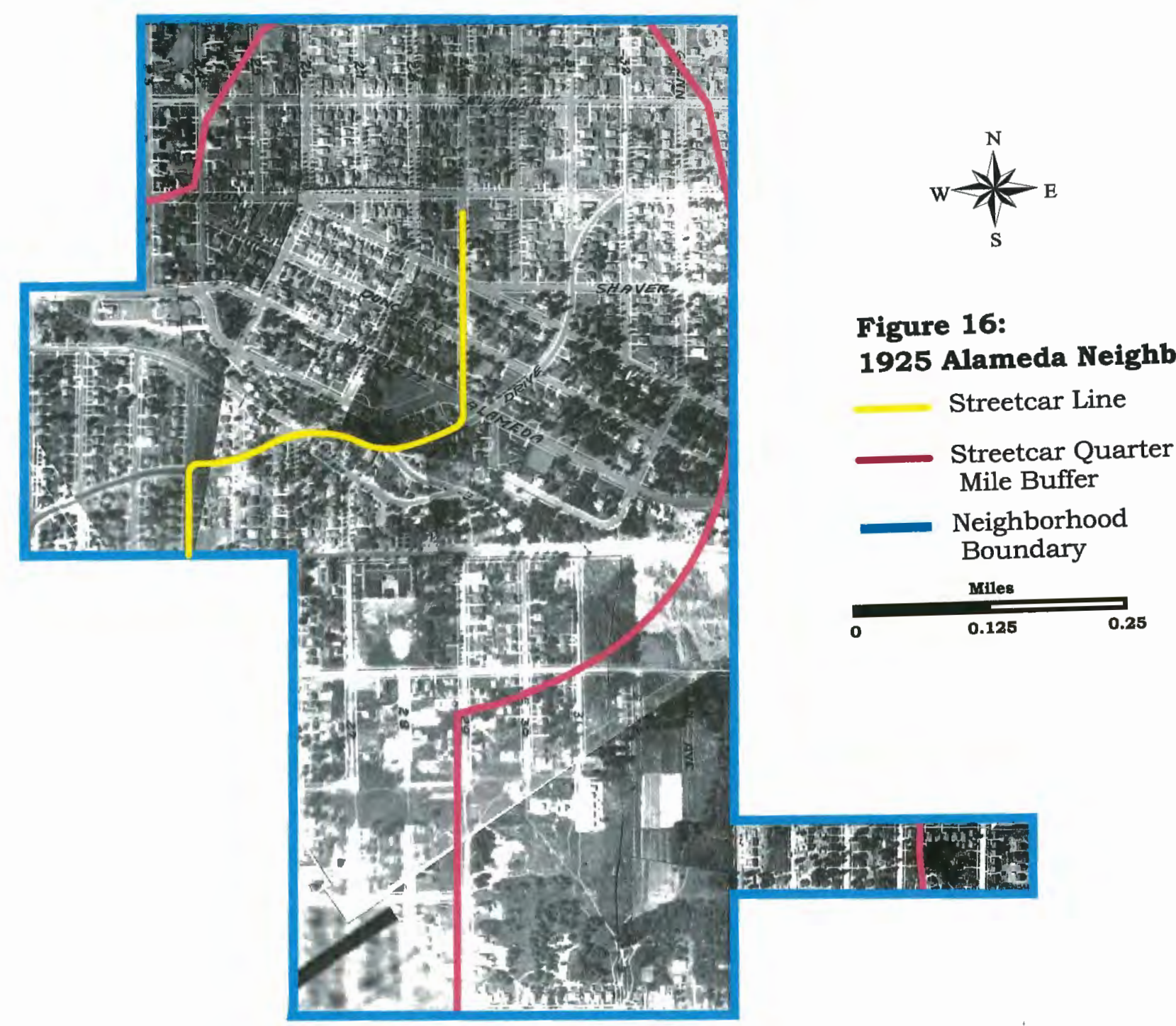




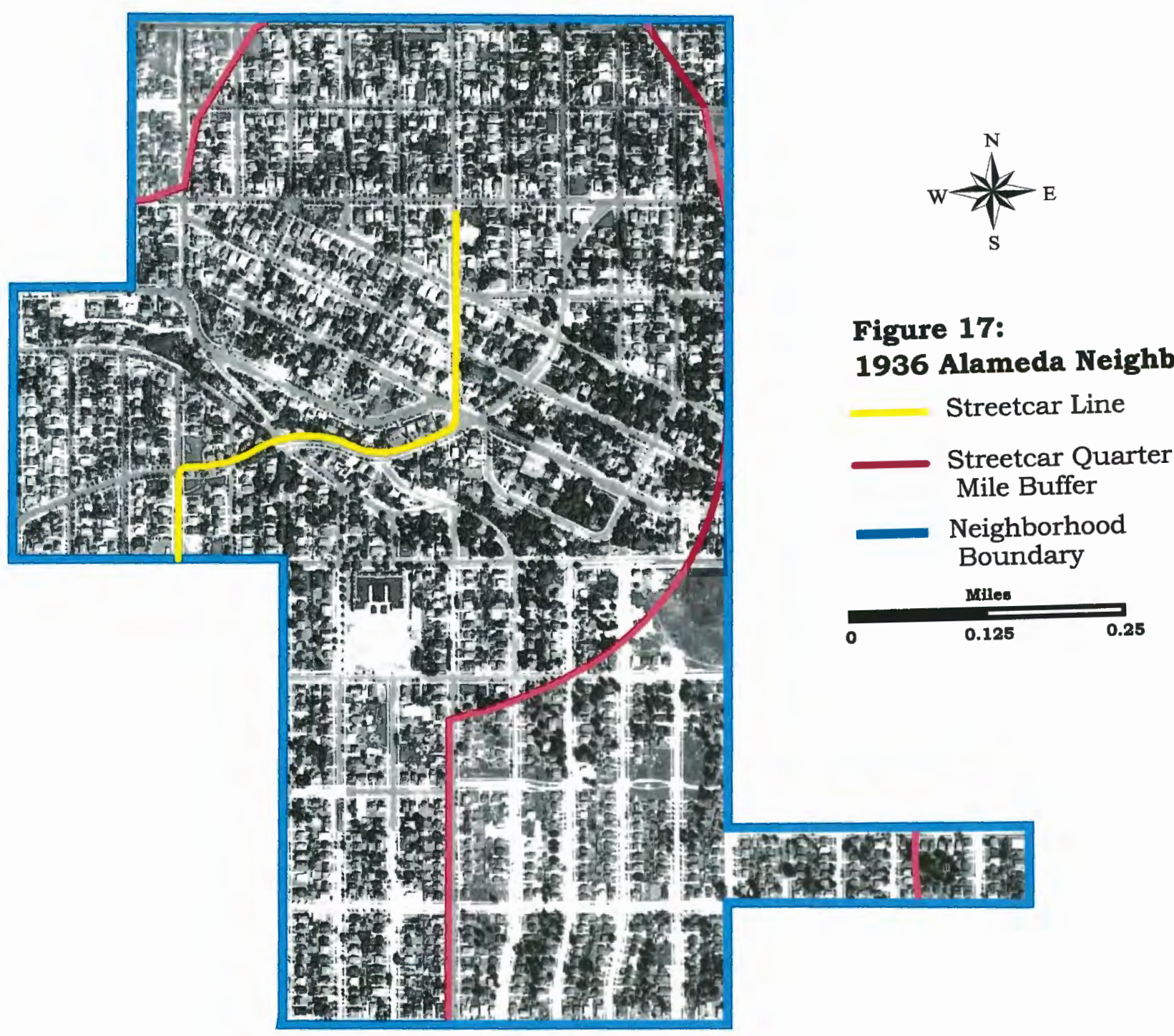




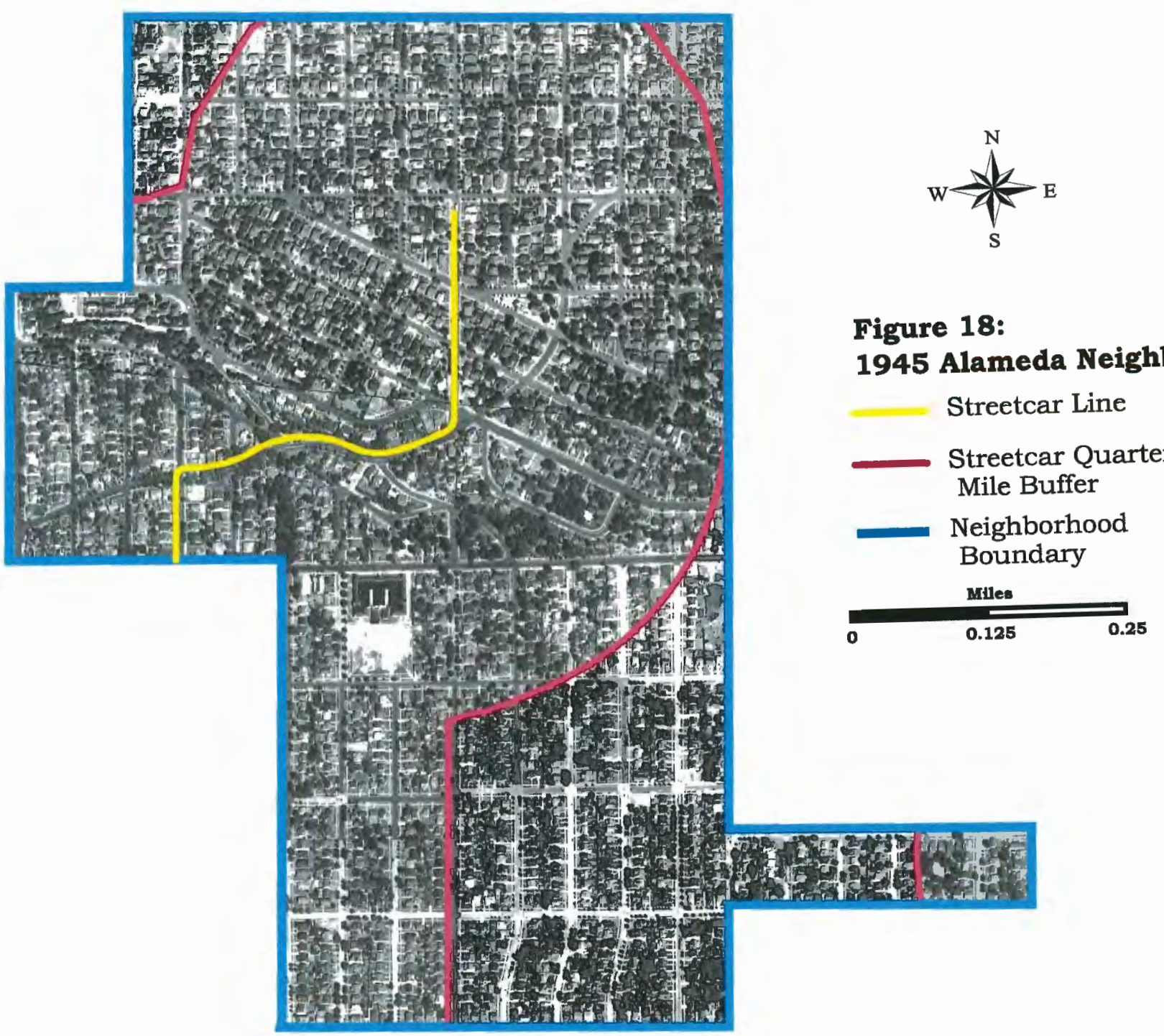




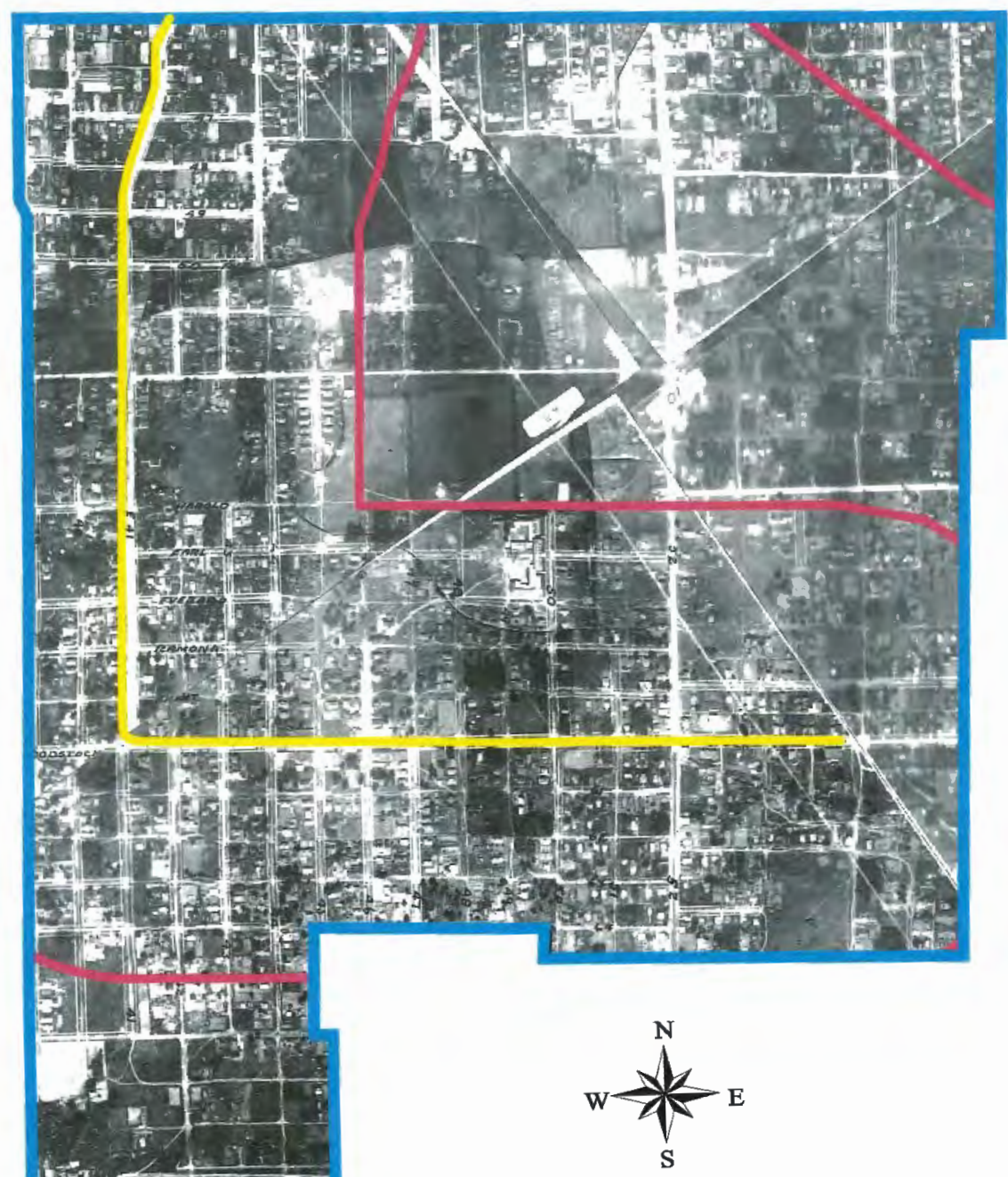

Figure 19:

1925 Woodstock Neighborhood
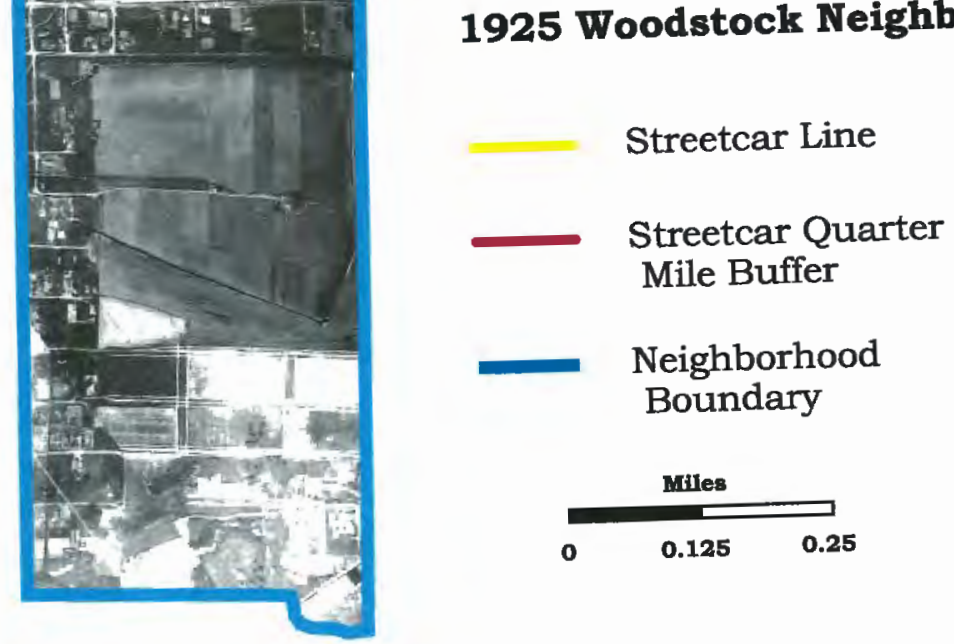


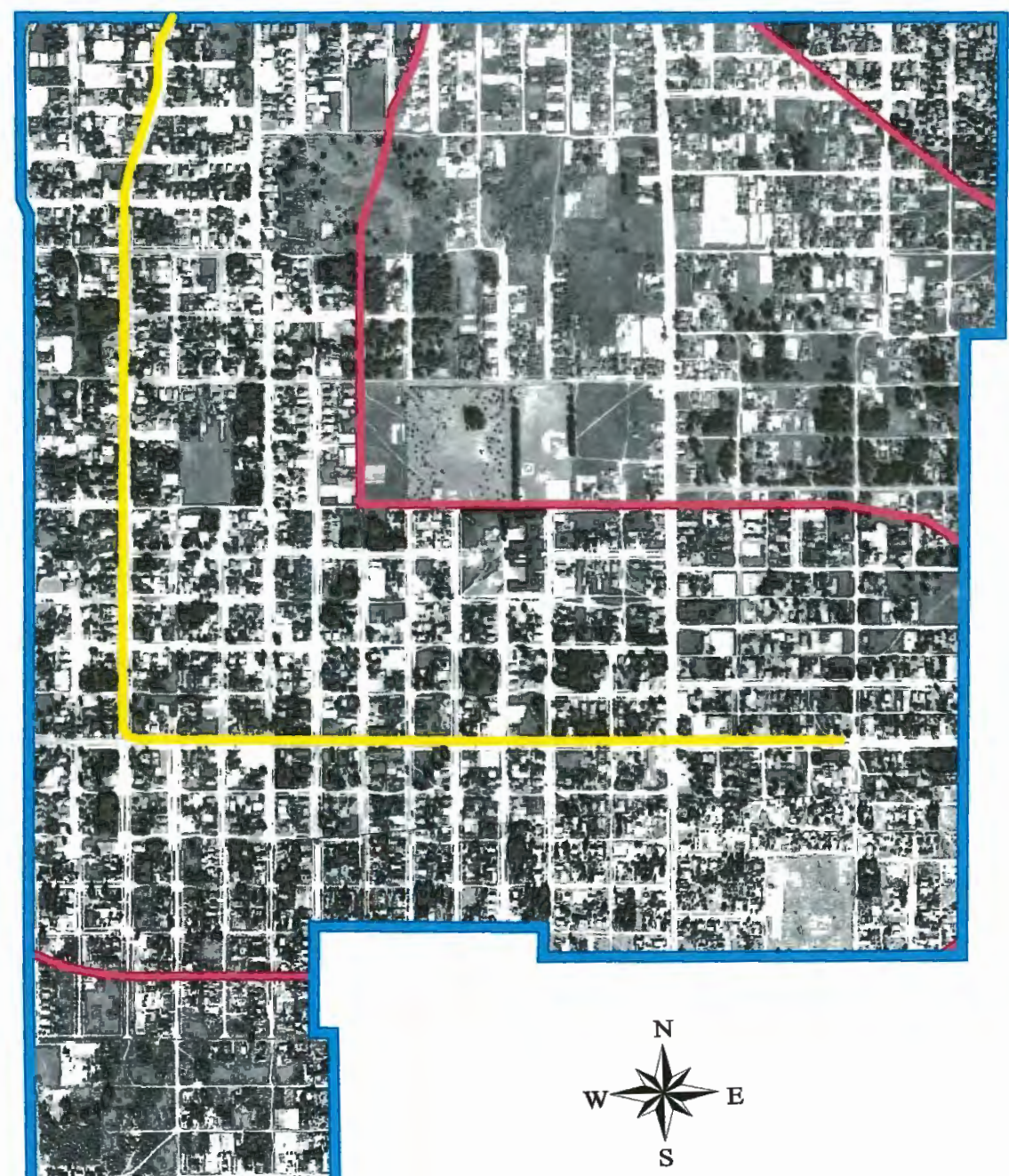

Figure 20: 1936 Woodstock Neighborhood

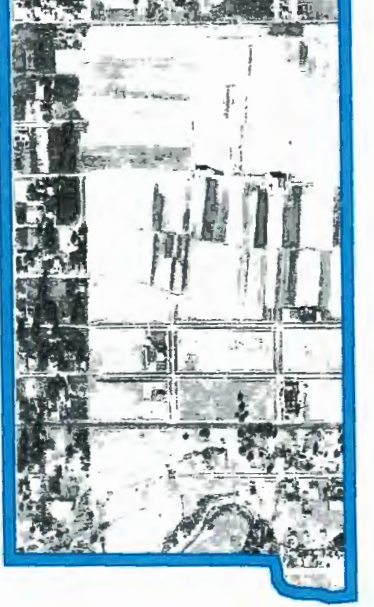

Streetcar Line

L Streetcar Quarter Mile Buffer

- Neighborhood Boundary

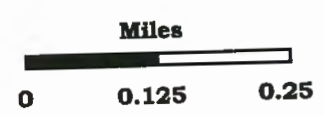




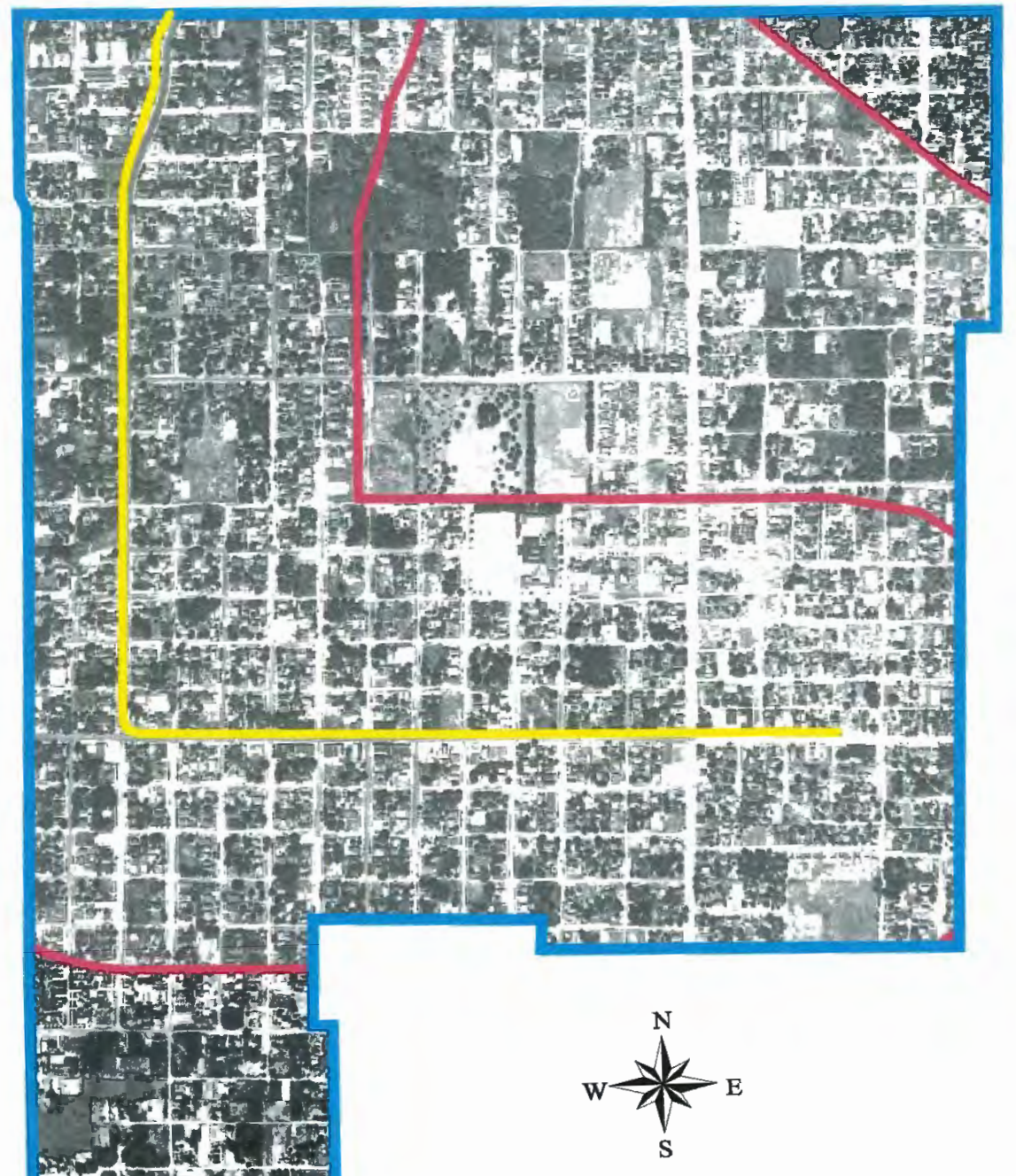

Figure 21:

1945 Woodstock Neighborhood

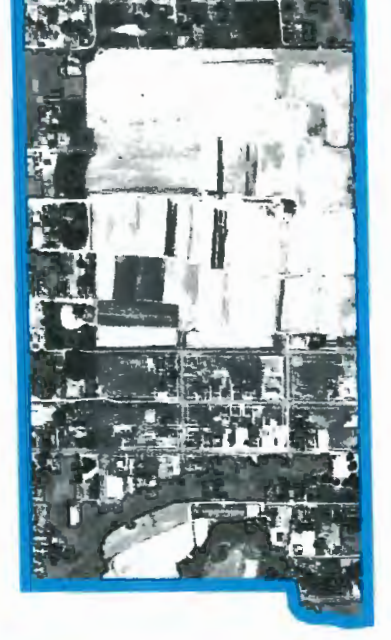

Streetcar Line

- Streetcar Quarter Mile Buffer

- Neighborhood

Boundary

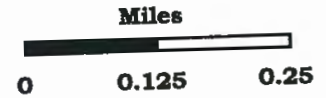




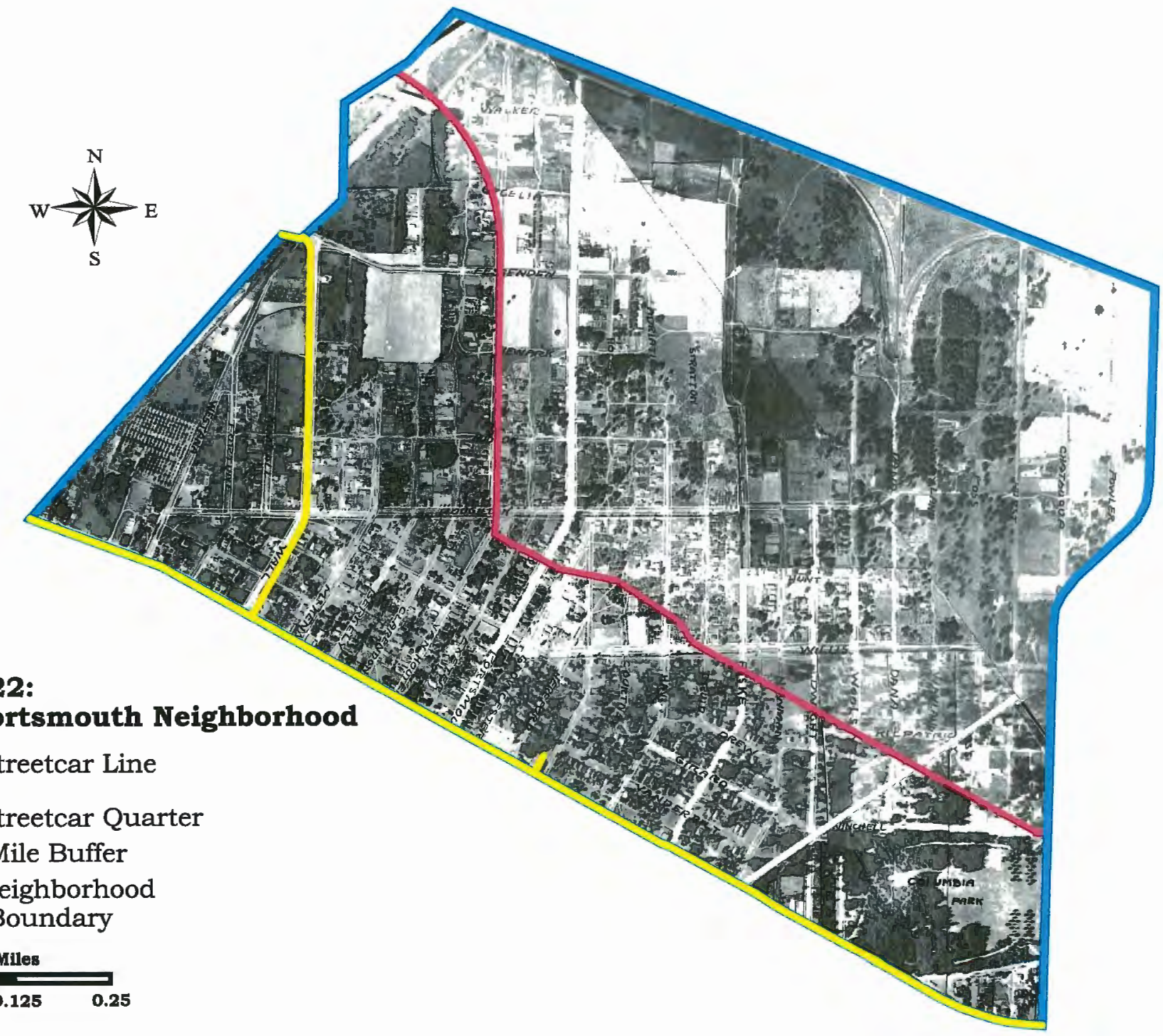

Figure 22:
1925 Portsmouth Neighborhood

Streetcar Line

- Streetcar Quarter

Mile Buffer

Neighborhood

Boundary

\begin{tabular}{lll} 
& Mules & \\
\hline & 0.125 & 0.25
\end{tabular}




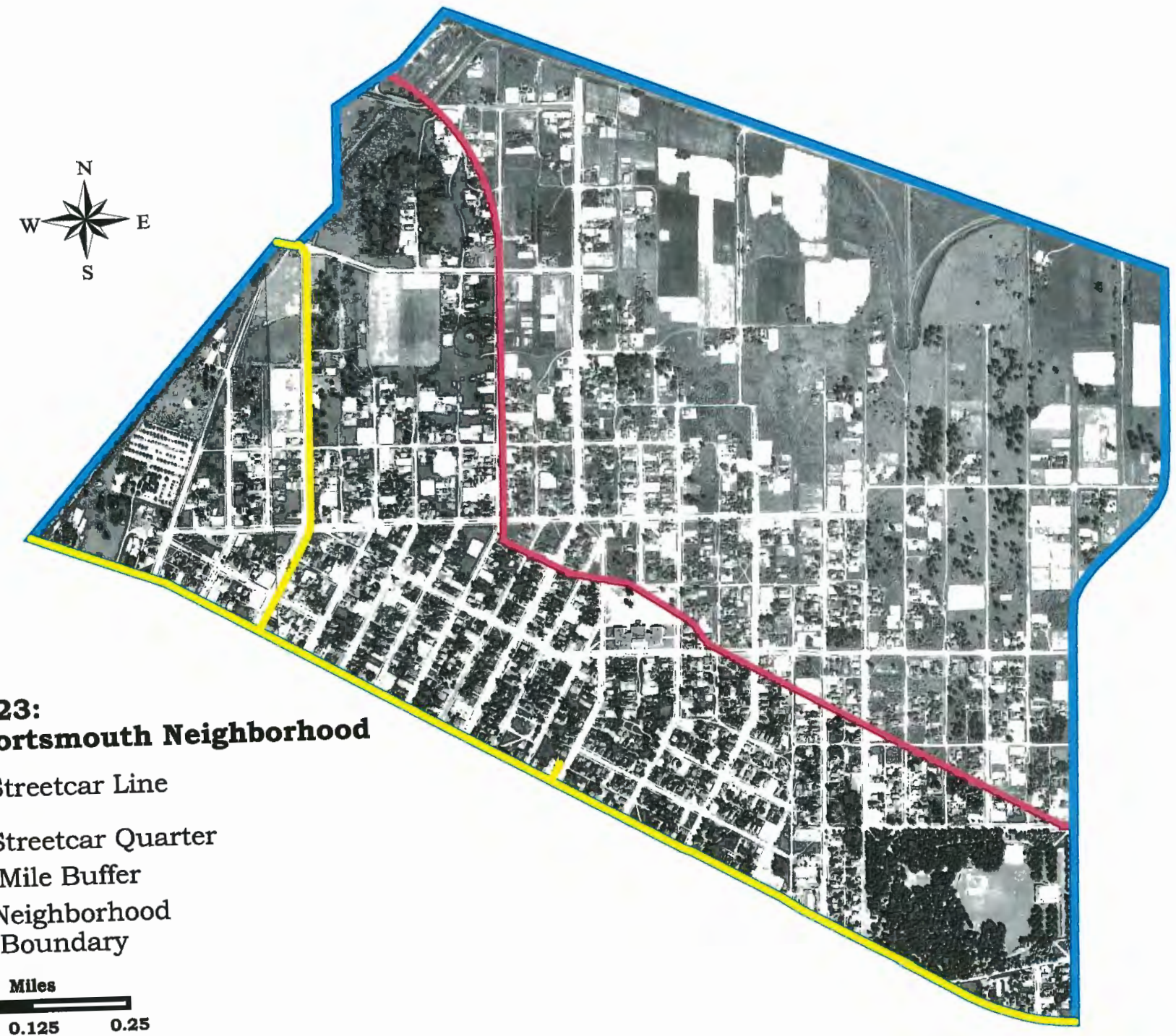




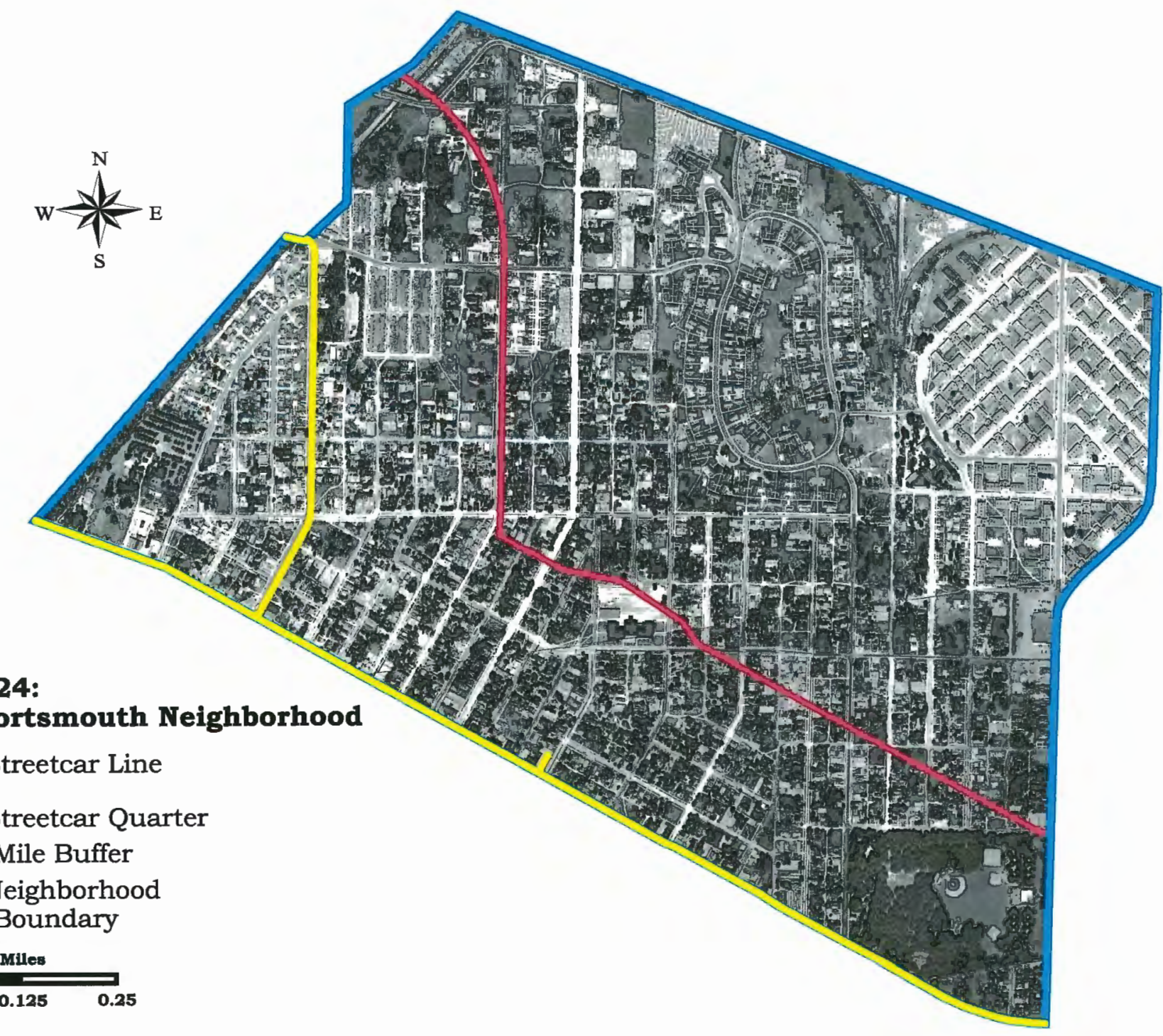

Figure 24:

1945 Portsmouth Neighborhood

- Streetcar Line

_ Streetcar Quarter Mile Buffer

- Neighborhood

Boundary

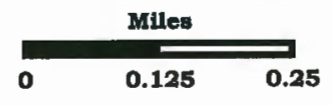


(MacColl, 1979, 70) made clear the upper-class nature of this neighborhood to potential residents. Alameda was serviced by a streetcar line with its terminus near the center of the neighborhood.

Neighborhoods like Alameda, built by developers who also financed the streetcar line as an amenity to residents, have housing and street patterns that are the result of conscious planning. These neighborhoods were also among the first to abandon the streetcar lines, even while use was peaking in the city overall (MacColl, 1979, 123). Considering the wealth of people living in these areas, it makes sense that the expense of the automobile would not have been prohibitive.

The Woodstock (Figures 19-21) neighborhood, in Southeast Portland, was originally zoned entirely multi-family residential; however, "before World War II, the (Planning) commission repealed second-class status" (Abbott, 1983, 114) for this and several other areas, and rezoned Woodstock to single family residential. The Waverly-Woodstock streetcar line, which terminated in the heart of the Woodstock neighborhood, was financed by citizens groups from the areas serviced by the line (Labbe, 1982), and began operation well before the turn of the century, in 1891. This is a reversal of the situation in those upscale east side neighborhoods such as Alameda, where developers initially financed the construction of the streetcar lines. In Woodstock, the community preceded electric streetcar lines.

The Portsmouth (Figures 22-24) neighborhood in North Portland provides the most dramatic visual changes seen in the aerial photography between the years 1925 and 1945. Like Woodstock, Portsmouth was accessible early by means of a transit 
line, the last steam line built in Portland. This line was electrified in 1903 (Labbe, 1980). "Other than walking, the steam line was the only mode of transportation for many residents, as city dwellers did not typically own horses. Most houses in Portsmouth were built within walking distance of Portsmouth Station" (City of Portland, 2002, 18). The city of Albina absorbed Portsmouth in 1891, to be itself consolidated into Portland later that same year (City of Portland, 2002).

Portsmouth today has median incomes and owner-occupied housing values below those of Portland as a whole (City of Portland, 2002). The dominant change apparent in the aerial photography is the development of Columbia Villa in the northeast corner of the neighborhood. A population influx, drawn by employment opportunities in Portland's shipyards associated with World War II, had caused acute housing shortages. Columbia Villa added over 400 apartments targeted to these shipyard workers, and represents "Portland's first public housing project" (Abbott, 1983, 131). The plan of this area displays the curvilinear street pattern and low densities in vogue at the time.

Today Columbia Villa is owned and operated by the Housing Authority of Portland. The recently adopted Portsmouth Neighborhood Plan includes a proposal to "deconstruct Columbia Villa with its 439 units of World War II temporary housing and replace it with a compact, pedestrian-friendly, mixed-use neighborhood," accomplished in part by "demolishing the existing looped street system and restoring the city's street grid to the site" (City of Portland, 2002, 11). One thing clear from the aerial photography is that Portland's grid street system can not really be "restored," 
since it had never been established, at least not before 1936. Columbia Villa was built on an area not reached by streetcar development.

These three neighborhoods - one planned by developers and targeted towards the affluent, one middle class, whose growth was controlled by those who lived there, and one with significant government influence on its neighborhood character - have differences that are clearly captured by the aerial photography. Alameda, for example, being closer to town, smaller, and more desirable because of its ridge location, has less vacant land. In all cases however, the 1925 photography displays high density building patterns and connected street network in the areas within one quarter mile of the streetcar line. Areas outside this buffer are, to a large degree, empty. As these areas fill in, they do so with generally larger blocks, resulting in a street grid with a lower intersection density, or with streets laid out in a curvilinear pattern. The building densities show similar patterns, initially clinging to the streetcar line. Later filling in of the remaining area appears more sparse and scattered.

\section{Variables and Sampling Frame}

The first decision to be made in approaching an analytical assessment of growth patterns is how to measure those changes. Three factors are repeatedly discussed in the literature, from Green and Monier to Calthorpe, Southworth and Krizek: housing density, street network connectivity and land use mix. This study will consider the first two of these variables. Land use mix is more difficult to quantify and more problematic to identify compared to the straightforward nature of density and connectivity measures, especially in the earlier photographs so soon after the 
establishment of land use zones. Also, because the focus of this study is on residential growth, I have purposely limited the study areas to those zoned residential, aiming for areas of single use.

Housing density simply considers the number of dwellings included within some unit of area. The only drawback associated with the use of aerial photography to measure this is the inability to discern the number of stories a building has, which could underestimate the actual density numbers. Because the study area is limited to areas zoned residential, I will operate under the assumption that a building and a residence are synonymous; an accurate description of the measure I am making is "building density in residential zones." In working with the photography, I do not believe this to be a major issue. The sampled areas were characteristically residential in appearance.

Street network connectivity is measured by the density of intersections over a unit area. In keeping with the research of Southworth and Krizek, the type of intersection is also considered. Each intersection in the network will also be attributed with the number of streets that connect with it, and weighted accordingly. For each area, the sum of the number of streets that connect with the intersection equals the weighted number of intersections. For example, a typical block in a grid network would have four intersections, each with four streets connecting to it. The weighted value given this network would be sixteen. If half the intersections have only three connecting streets, the weighted value would be fourteen, a lower value of connectivity. This method thus distinguishes between " $T$ " and " $\mathrm{X}$ " intersections. 
The next consideration is the area unit that is used to measure these variables. Green and Monier looked for areas that represented clear breaks in density, and used those natural delineations. I chose to use the approach taken by Southworth and by Krizek, using a grid and measuring variables within that square area. There are negatives involved in using a raster analysis; natural breaks and boundaries for example may not perfectly conform to the extent of the grid. In the case of this study, the edges of the land use zones are at times crossed, when the majority of the cell lies in the residential area. The consistent size and compact shape of the sample areas make this option the most attractive. There is no need to normalize the resulting data in order to create a density measurement, since the area covered by each cell is equal.

A wide variation in size of the grid cell exists between the 2000 square feet used by Southworth and the 150 square meters favored by Krizek. A recurring theme when discussing transit use is the distance that people are willing to walk to access that transit. This distance is most often quantified as between one-quarter and onehalf of a mile. This is true both in historical analyses of urban growth and New Urbanist planned developments. Warner $(1978,61)$ uses the figure 500 yards, which calculates to approximately 0.28 miles. Calthorpe considers 2000 feet $(0.38$ miles $)$ a “comfortable walking distance" $(1993,56)$. Krizek (under review, 11) identifies a walking distance to be a quarter mile.

My decision was to take the shortest of these distances, a quarter mile, and divide that length in half for the extent across the grid. The raster grids are therefore 660 square feet, or ten acres in size. My rationale in choosing this size was to have a 
large enough grid that the measurements I take are not significantly influenced by small areas that could have abnormal characteristics, but small enough to capture differences more finely tuned than would be accomplished using a quarter mile grid. An additional consideration in the decision to divide the quarter mile distance in half was that measurements within the grid will be considered in relation to their distance from the streetcar lines. Given the case that a grid intersects a streetcar line, the maximum distance a point within the cell could theoretically be from the streetcar is the length of the hypotenuse of that cell, approximately 933 feet. Therefore, I opted for the smaller analysis grid to avoid including such distant areas.

Previously I had decided to limit my study area to the east side, within the city limits, and to areas zoned residential. I decided not to exclude the long, narrow strips of land use included in the fourth zone, which followed along the streetcar routes. My familiarity with the study area led me to conclude that although these areas were unrestricted in their zoning they tended to remain residential, and I did not want to exclude areas so important to the study. Earlier experiences I had working with the zoning data led me to also exclude parks, to avoid large vacant land areas in the analysis. Parks are not excluded from the 1927 land use zones; Mt. Tabor Park, for example, is zoned single family residential. A detailed step-by-step process of the creation and attribution of the sample frame is included in Appendix B. The result was a total of 1,926 10-acre grid cells in the sample frame, illustrated in Figure 25.

I assigned values to the grid cells based on their proximity to the streetcar lines and to the urban center, represented by City Hall. Figures 26 and 27 show the results 


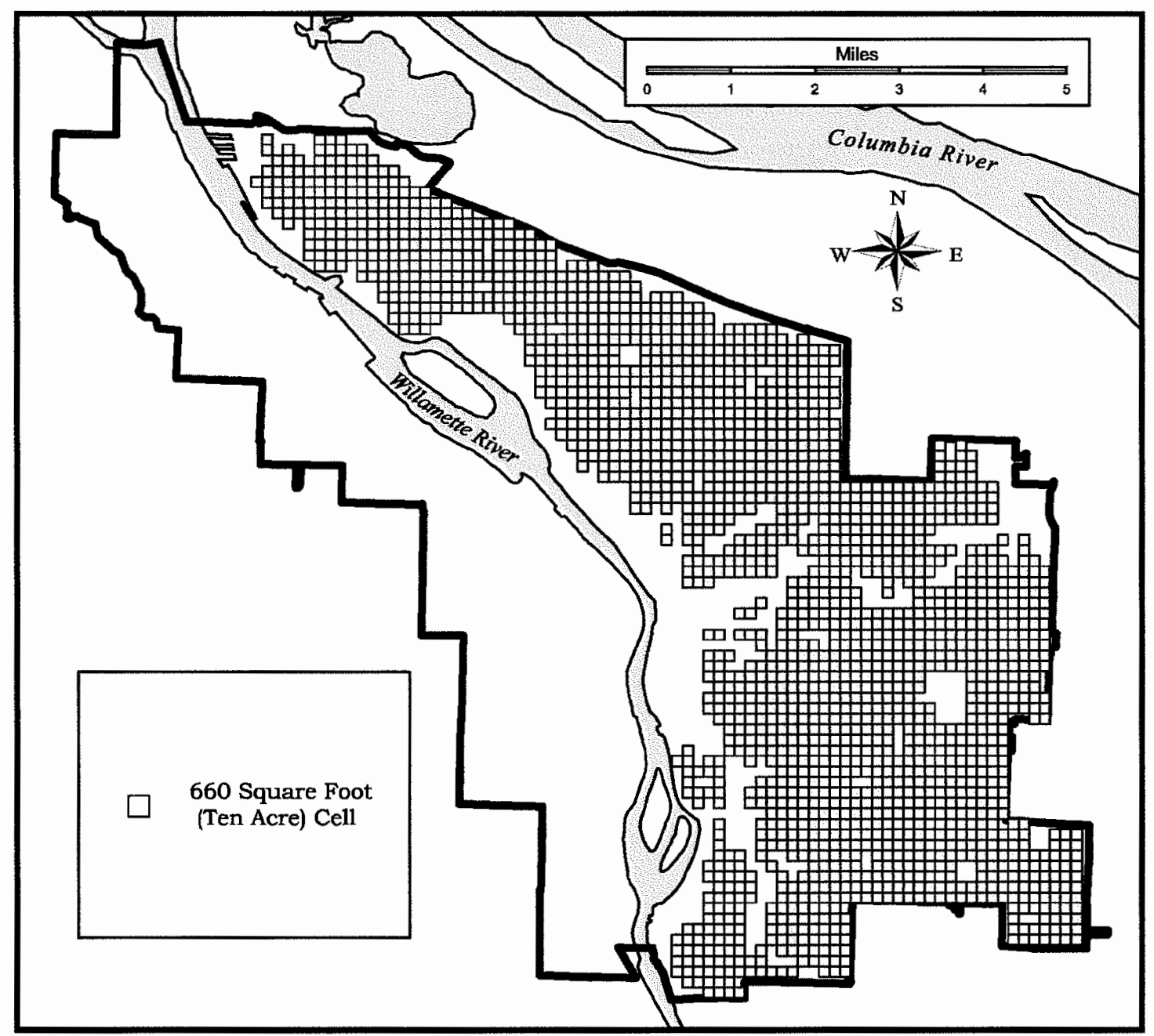

Figure 25: Study Area Sample Frame

These are the 1,926 ten acre grid cells that meet all the conditions of the study area: they are on Portland's east side, they are zoned residential, parks are excluded, and coverage from the 1925 aerial photography exists. From this sample frame the sample areas are selected. 


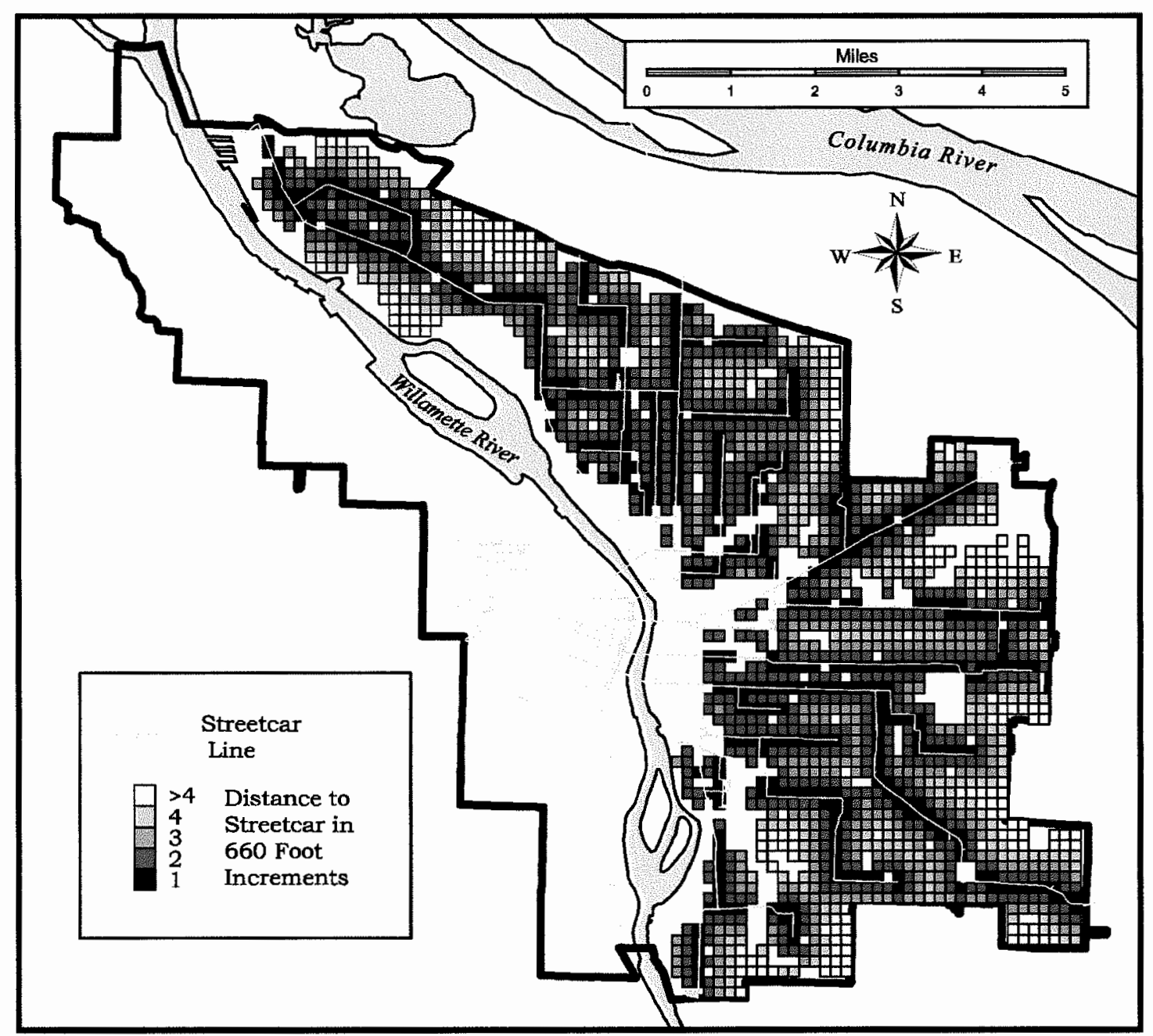

Figure 26: Study Area Sample Frame

Attributed with Distance to the Streetcar Lines

The grid cells were attributed based on their distance to the streetcar lines. The Class 1 grid cells intersect with the streetcar lines, Class 2 cells are within 660 feet, Class 3 are within 1320 feet, and so on. Although this attribute ranged in value from 1 to $8,92 \%$ fall within the first four groups $(1,768$ of the total 1,926$)$. 


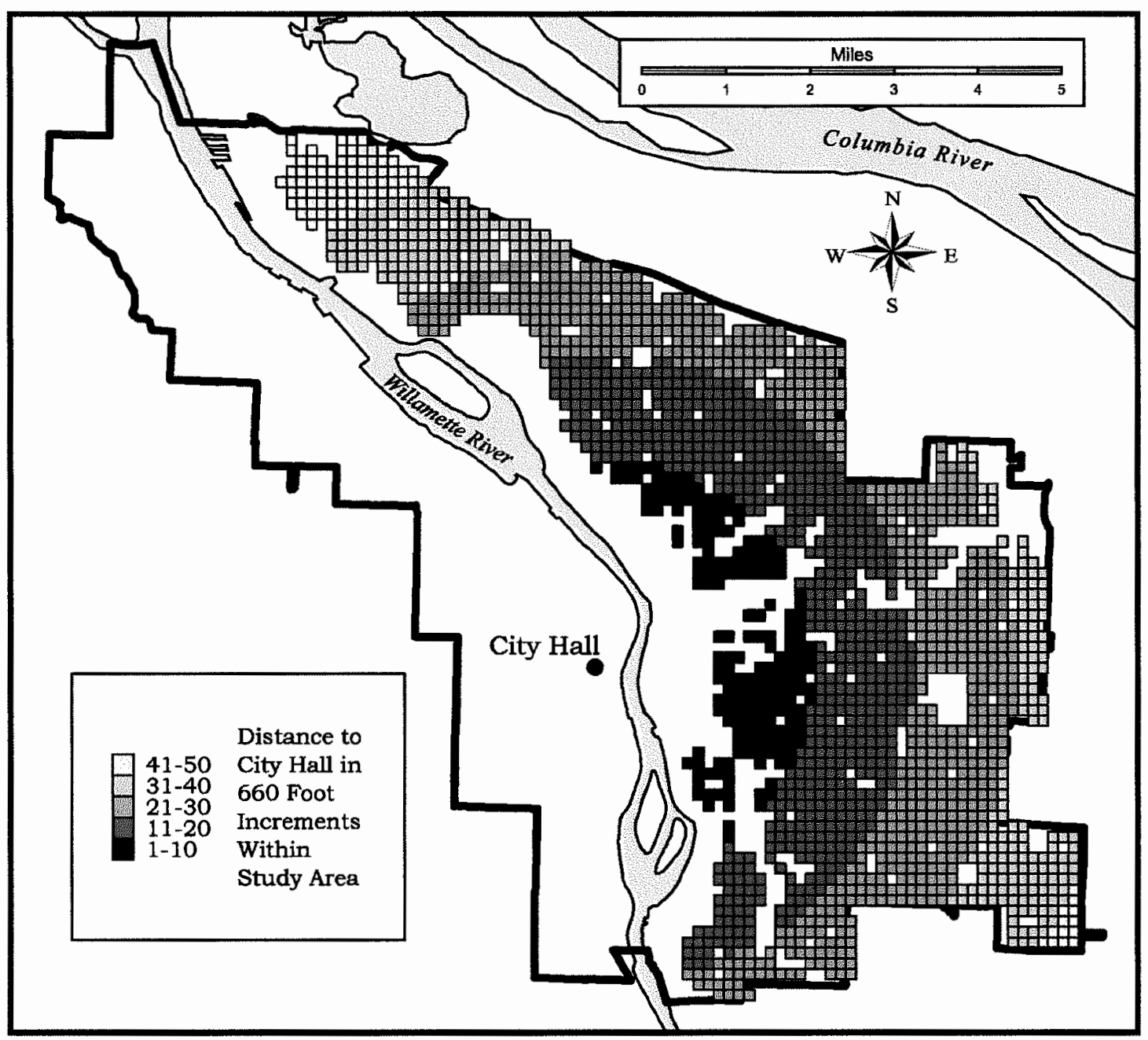

Figure 27: Study Area Sample Frame

Attributed with Distance to City Hall

Attributed using a similar process as the attribution based on distance to the streetcar lines, distance to City Hall was also attached to the grid cells. This attribute ranged from 10 to 59 , but was reclassed to range from 1 to 50, as shown here. The data shown here is classified into groups of 10 . 
of these processes. For any given cell, therefore, it was possible to consider the measures of density and connectivity contained within in relation to these two values.

In testing his model, Adams (1970) used transects either outward from the urban center or perpendicular to transit lines coming from the center; by attributing the cells in the manner that I have, am doing essentially the same thing, but have the advantage of not being constrained to the transects. Considering cells along the range of attribute_values based on the distance to City Hall is similar to measuring along a transect out from the center. Considering cells along the range of their distance to the streetcar lines is equivalent to using a transect perpendicular to a transit line.

\section{$\underline{\text { Sampling Methodology }}$}

This study compares two measures of urban growth — density and connectivity - over a spatial range and a temporal range. The spatial range has two parts, distance to the urban center and distance to the streetcar line, which need to be considered in choosing which cells are to be included in the analysis. Temporal changes are included by considering the same areas at three points over a range of twenty years.

My goal was to ensure an adequate distribution of sample cells over the spatial extent of both these two factors, and a sample that was representative of the whole. Because my interest was in whether proximity to the streetcar caused deviations from concentricity, thirty samples for each category of that attribute would be necessary for inferential statistics that could be used to draw conclusions about the structure of the entire study area. I ultimately decided to sample only the first four classes; not only 
would the changes I expect to see be within this distance of the streetcar lines, but these cells comprised 1768 of the total 1926 , approximately $92 \%$ of the entire study area. Therefore, a total of 120 sample cells were selected through what is best described as a weighted stratified sampling.

To distribute the sample cells over the extent of distance from city hall, I decided that once any particular combination of the two spatial attributes (distance to the streetcar and distance to City Hall) had been chosen, that I would discard any subsequent sample with the same combination. This process was amended in those cases where a large number of that combination existed. Ultimately the number of samples I allowed for each particular combination was not to exceed ten percent of the total rounded up to the next ten. For example, if a particular combination of distance to the streetcar and distance to City Hall occurred in the sample frame thirty-three times, I rounded that value to forty, and allowed four of those combinations to be included in the sample. By doing this, my sample was spread throughout the study area and still represented the distribution of the whole. The actual manner of selection was decidedly low-tech: I printed tables for each of the shapefiles, cut them along the rows so that I knew the unique identifier and the attribute values, and placed them in a container. I then selected them, crossing that combination off the list as I went along or discarding them if I had already reached the maximum number allowable for that combination. Figure 28 displays the results, and Appendix C contains the spatial attributes of the sample cells. 


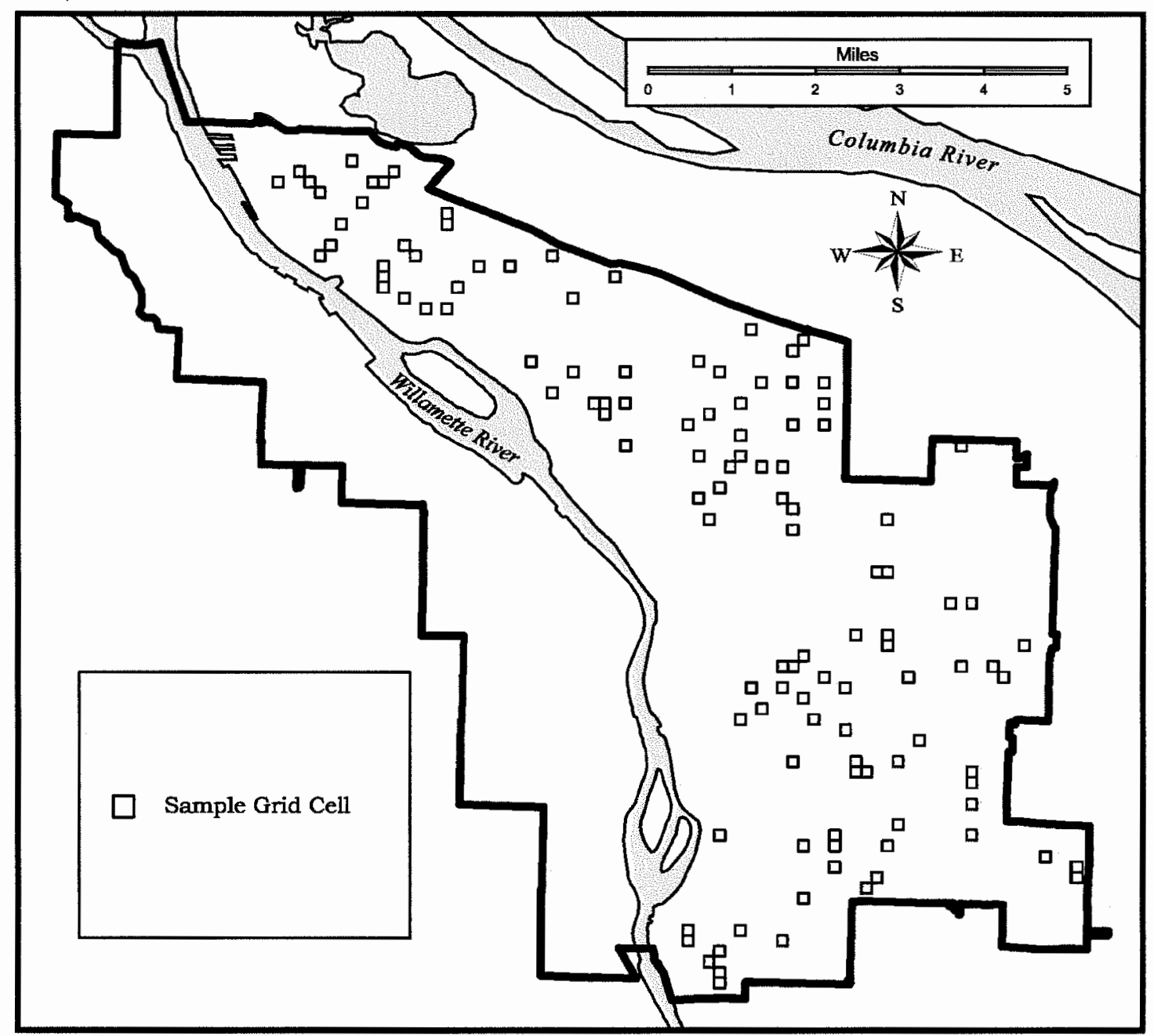

Figure 28: Sample Cells Selected from Sample Frame These 120 sample cells are the total of 30 for each of the first four classes of distance to the streetcar lines. A weighted stratified sampling methodology was used to distribute the cells throughout the study area and represent the characteristics of the whole. 


\section{Digitizing and Attribution}

Once the sample areas were chosen the next step was to digitize the locations of buildings and intersections, and attribute them as necessary. For each of the three years being considered, I went through the 120 sample cells and point digitized the locations of buildings and street intersections. The digitized buildings data did not need any attributes other than an identifier, a composite of the cell identifier, year, and sequential number. The street intersection points received a similar identifier, as well as an attribute indicating the number of streets connecting to that intersection. This value ranged from 1 for the end point of a cul-de-sac, to a maximum of 5.

RLIS was used as ancillary data in this process, particularly the taxlot and street shapefiles. In digitizing the buildings, I followed a guideline of one building per taxlot, so not to include outbuildings in the analysis. This was not a rule; that would defeat the purpose of using aerial photography, and there were times when this guideline clearly had to be ignored, based on my judgment. Once I had identified the locations of buildings I would check them against the yearbuilt attribute of the RLIS taxlots. There were occasions when I was clearly looking at a vacant lot in the photography when RLIS indicated it should be built, but in general there was a correlation. More common was the case that a building existed and RLIS contained a later year for the taxlot, probably a case where the attribute reflected a rebuilt lot. For example, if a lot was originally built in 1920, but that building torn down and another constructed in 1950 , the yearbuilt attribute would contain the later date, but a building would be visible in the photography. I relied more heavily on RLIS in some of the 
1925 photography when the image quality was poor or along the abraded edge of the photograph.

The taxlot data also contains an $x-y$ point location indicating the midpoint of the lot, and this can be brought into the GIS as an event theme. I used these attributes to determine whether a lot that was partially within the cell should be included, based on whether the point location was within the cell. I had expected digitizing to be an additive process as time progressed, and for the most part it was. The locations of buildings in later years generally included the locations in earlier years, though I was surprised at the number of times this was not the case, primarily in the more remote areas of the city. Figure 29 provides an example of buildings digitized within a single sample cell, and shows the additive nature of the growth.

The digitizing process of the transportation network was somewhat more complex. I had to determine what constituted a street, and this was not so simple at times. Especially in the earlier photography, there were often routes that appeared to be used for transportation by foot or by horse. My interest was to identify the established transportation network at a time when the conception of that was in flux. Much attention was focused on improving the state of the roads in the late 1920s and early 1930s (Abbott, 1983). This process required an amount of subjectivity. I tended to include a road if it appeared linear rather than sinuous in nature; its permanence, either to the modern day network or over the twenty year period included in the study, also bolstered the case for inclusion. RLIS again served as a tool; in those cases where the street survived to the present day, the intersection of the RLIS street centerlines 


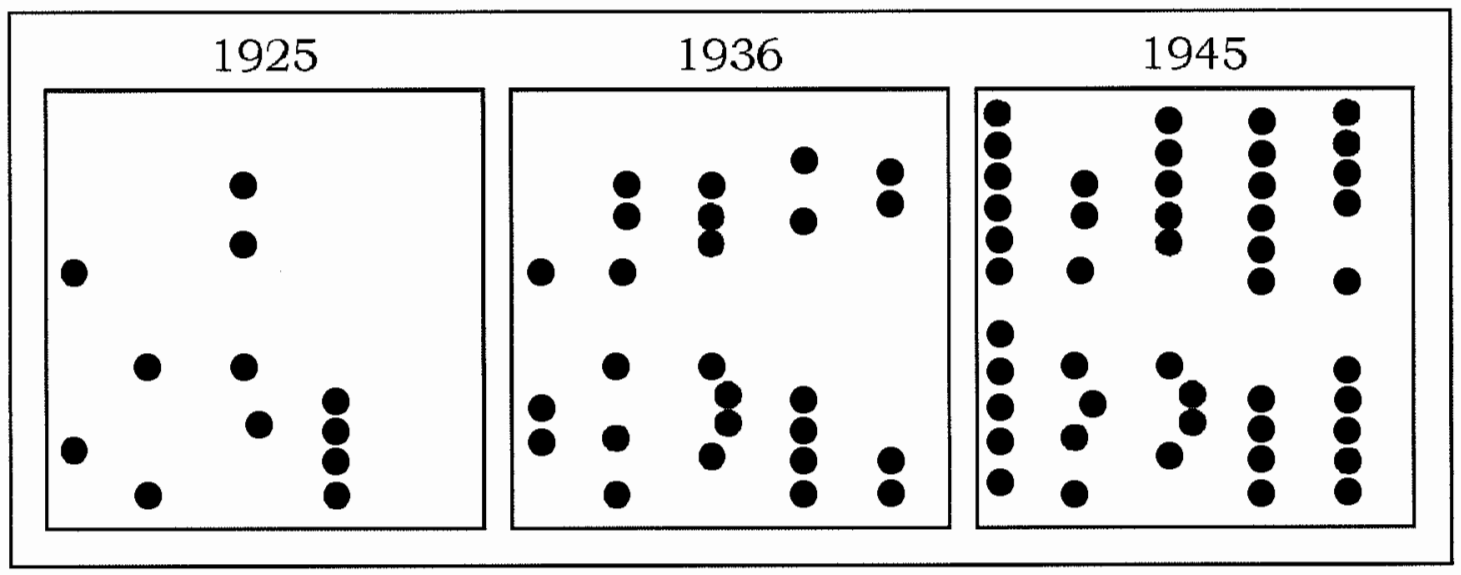

Figure 29: Building Locations Digitized within a

Grid Cell from 1925 to 1945

This sample cell (ID \# 416) is in the fourth class of distance to the streetcar and in the twenty-second class of distance to City Hall. It is therefore not surprising to observe the large degree of growth in this 10 -acre area over twenty years; until the advent of the automobile, this area would not have been attractive to potential residents. Once the car had become commonplace that situation changed throughout Portland's eastside neighborhoods. 
assisted in determining whether an intersection along the edge of the grid cell would be included in the study. While initially I digitized all intersections, in keeping with the methodology of Southworth and Krizek I included only those connected to three or more streets in the ultimate analysis. Intersections with fewer connecting streets offer no choice of routes. The data collected for each sample cell is presented in Appendix D.

\section{Model of Expected}

Based on the ideas contained within the urban models, New Urbanist concepts of historic growth, and the neighborhood examples in the aerial photography, what changes would we expect to see over the spatial and temporal extent of theses measurements?

Figure 30 provides a basis for comparison. Measurements along the horizontal axis reflect changes in time. The column farthest left contains variable values for 1925, the central column contains variable values for 1936, with the values for 1945 in the column on the right. The vertical axis, from the bottom to the top, contains the measurements of the variables for the classes ascribed to the sample cells based on their distance from the streetcar.

For variables of dwelling density and street network connectivity, we would expect the areas within walking distance of the streetcar, the first two classes along the spatial axis, to be high in value. That is, we would expect a high density of buildings 


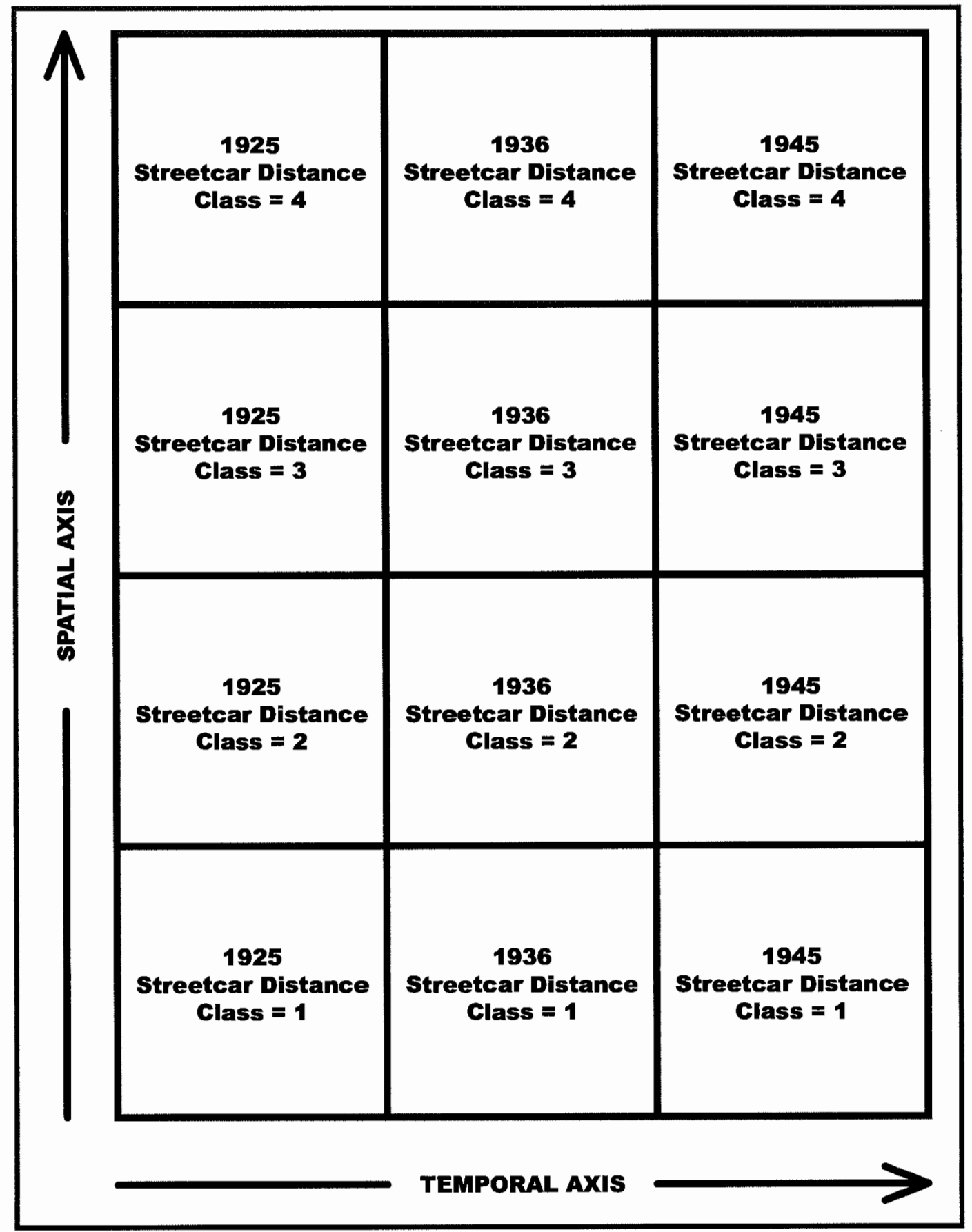

Figure 30: Spatial-Temporal Model

For Comparison of Variable Measurements

This model provides a basis for comparison of the density and connectivity measurements. Their relationship to the streetcar lines, and how that relationship changes with time, can be seen. 
and a highly connected street network. The character of these areas should have been established by 1925 and should not exhibit much change over the twenty year period being considered. Those areas beyond walking distance from the streetcars should show significant change with the increase in automobile use. In 1925, these areas should be essentially undeveloped, but grow steadily through 1945 . Recall that not until after 1945 were large areas beyond the older city limits opened up with highway construction. As the areas in the third and fourth classes along the spatial axis become accessible, we would expect the type of building that occurs to reflect the change in transportation. Distance to the streetcar should be no factor. Even when fully developed, however, both the density and connectivity variables should attain levels significantly less than those built during the streetcar era. The results should be something like what is seen in Figure 31. Higher measures are represented with darker shades of gray in all the graphics to follow. 


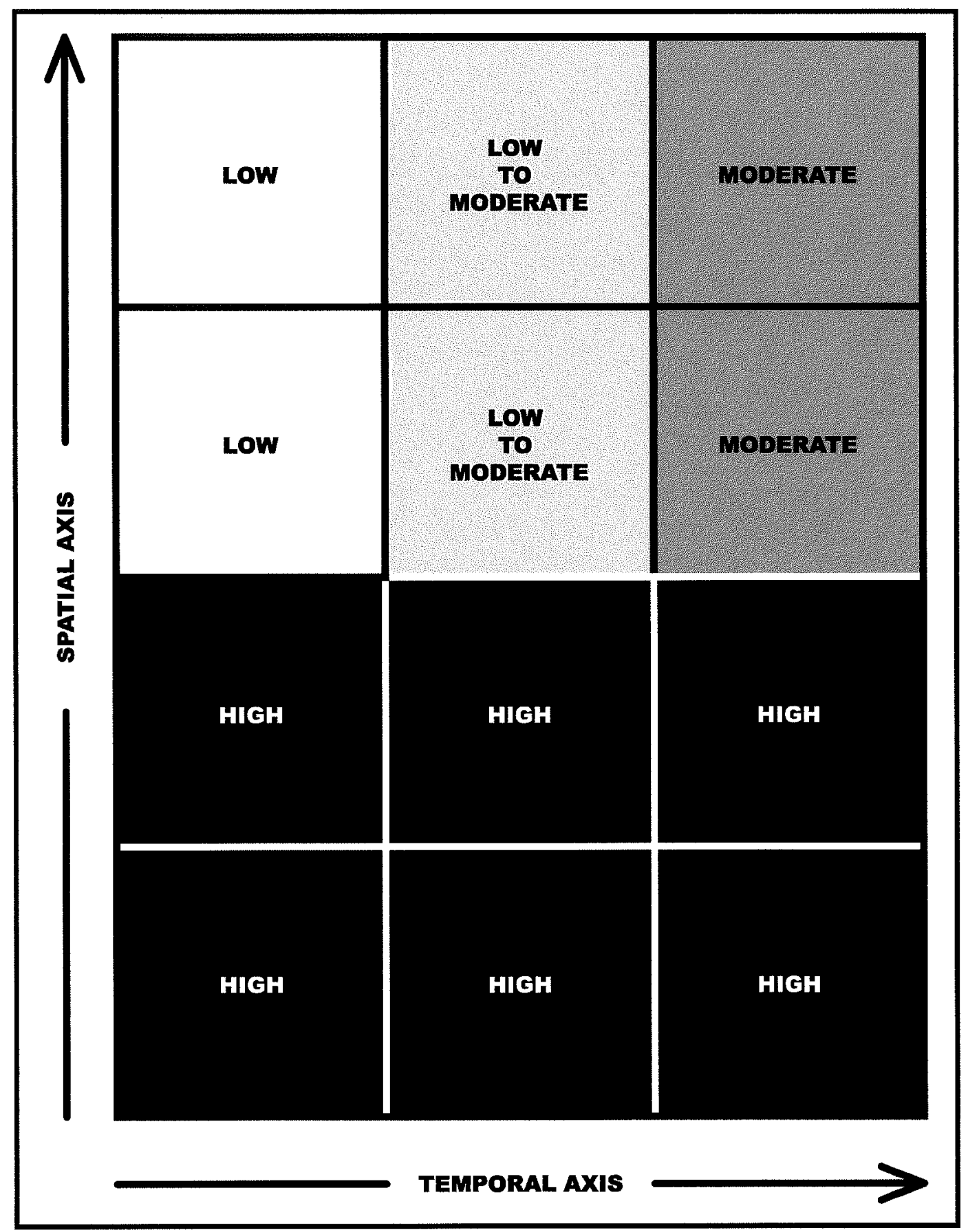

Figure 31: Model of Expected Comparative Variable Measurements Based on the urban models, New Urbanist ideas about urban growth, and the neighborhood examples, this is the pattern we would expect to see. High density and connectivity measures should be established early near the streetcar lines; the more distant areas should grow rapidly, from essentially empty to automobile-type development. 


\section{Chapter 5: Data Analysis}

\section{Descriptive Statistics and Correlation}

This model considers the values of the variables on a comparative basis, whether the values are more or less than those horizontally and vertically adjacent. While I collect the data on the interval/ratio level, ultimately I consider it on the ordinal level. For this reason I will consider two measures of central tendency, the mean for data at the interval/ratio level and the median for the ordinal level.

The descriptive measures for dwelling unit density, shown in Figure 32, look promising. Along the temporal axis, the number of buildings in those cells that intersect the streetcar lines range from the low thirties to the low forties, while those in the most distant areas nearly triple, from just over ten to just under thirty, suggesting established dense urban form near the streetcars and rapid growth in other areas. Across the spatial axis, the difference between the cells near to and far from the streetcar lines decreases with time, but even by 1945 the areas far from the streetcars have not attained the same levels of density, supporting the idea that the growth associated with the automobile takes a different form.

The descriptive measures for street network connectivity, shown in Figure 33, display a similar pattern, albeit over a smaller range of values. Weak but still significant correlation at $95 \%$ confidence is found between the two variables for each year; the correlation decreases with each year. The same results are found using the parametric Pearson Correlation and nonparametric equivalents (Spearman's Rho and Kendall's Tau). 


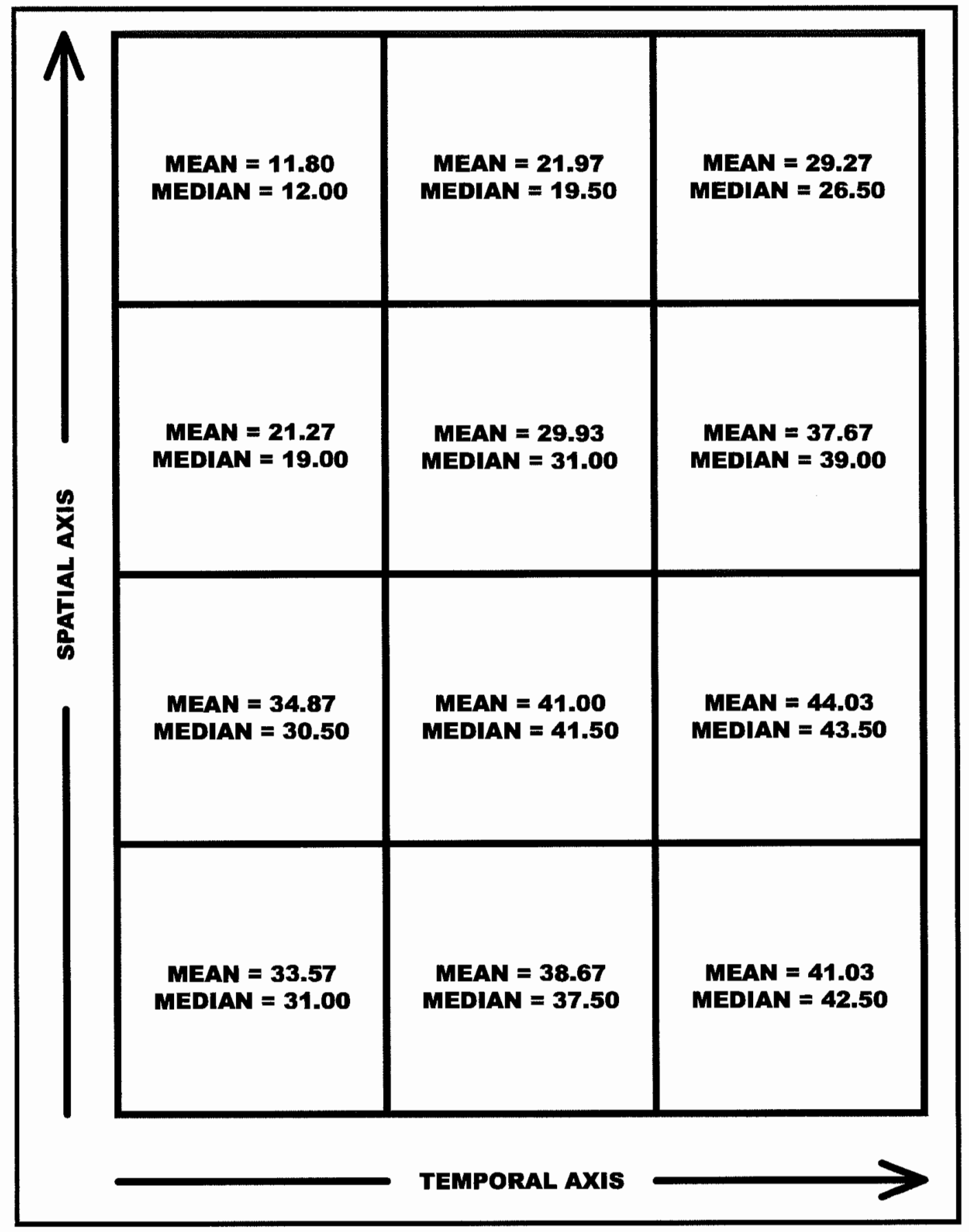

Figure 32: Dwelling Unit Density Descriptive Statistics The areas closer to the streetcar exhibit much less increase over time in these density values, while more than doubling in the cells furthest from the streetcar. Notice too that while the gap between near and far areas closes over time, the automobile development appears less dense. 


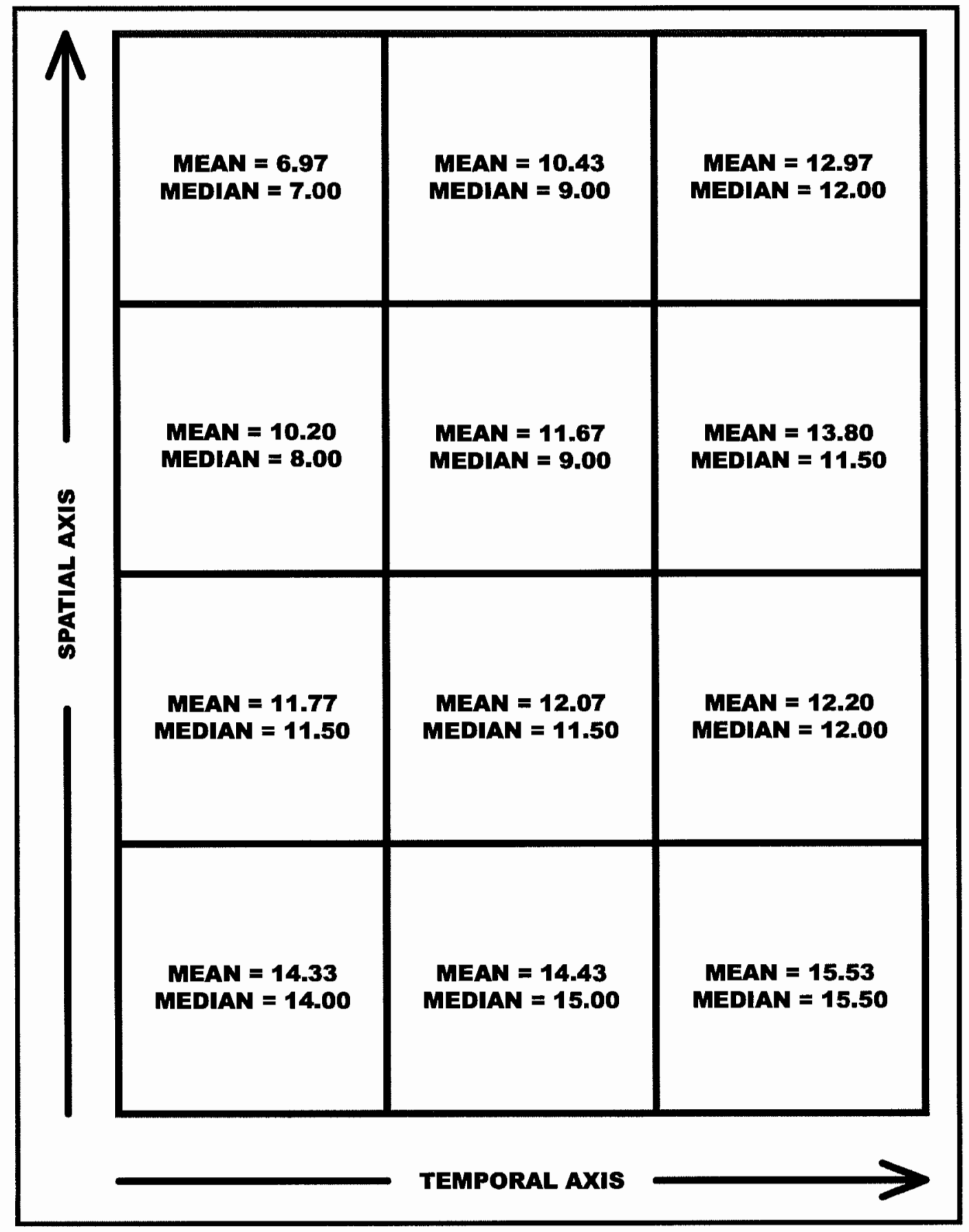

Figure 33: Street Network Connectivity Descriptive Statistics These measurements suggest a pattern similar to that of the dwelling unit densities, although with a smaller range in values. 
As measures of urban growth, residential density and street connectivity follow roughly the same pattern.

\section{Inferential Statistics}

While descriptive statistics can inform a discussion of the data, inferential statistics are needed to determine whether similar statements are warranted regarding the study area as a whole. Inferential statistics fall into two categories, parametric and nonparametric. Parametric tests require that four conditions be met. First, the input data must be collected at the interval/ratio level of measurement. This condition has been met in this study. Second, the sampling methodology must be random and the samples independent. I have described my sampling technique. The third and fourth conditions are that the data are normally distributed and have equal variance, or homoscedasticity. Test results will only be discussed in general terms in the body of this thesis; critical values and test statistics for all tests are listed in Appendix E.

Levene's tests confirm that an assumption of homoscedasticity is valid for all the data collected in this study. That is, neither variable has significantly different variance between the different years. However, the same cannot be said for the assumption of a normal distribution. I used two tests, the Kolmogorov-Smirnov test and the Shapiro-Wilk test, to test the assumption of normal distribution for each variable for each year. The Kolmogorov-Smirnov test estimates the population means and variance from the sample data. Therefore, using this test it becomes more difficult to reject the null hypothesis that the sample data comes from a population with normal distribution. The dwelling density data for 1936 and 1945 are found to be normal; the 
null hypothesis for dwelling unit density in 1925 is rejected using the Shapiro-Wilk test but not the Kolmogorov-Smirnov test at the same confidence. The assumption of normal distribution for the street connectivity data is easily rejected by all the tests.

The parametric tests I use are fairly robust. That is, they yield valid results even when all the assumptions are not met by the data (Burt and Barber, 1996). Because for the most part the dwelling density data meet the requirements, I elected to use only parametric tests on this set of data. Rogerson (2001) recommends this course of action when most but not all of the assumptions for a robust parametric test are met. Because the street connectivity data are so clearly not from a normal distribution, my choice was to use both parametric tests and their nonparametric equivalents on this set of data.

The first relationship between the variables that I examine is along the entire extent of the temporal axis for each class of distance from the streetcar. My expectation is that the areas near the streetcar will not be shown to differ significantly from one another, while the opposite should be true for the areas distant from the transit lines. The tests for the comparison of more than two means are the ANOVA (Analysis of Variance) parametric test, and the nonparametric Kruskal-Wallis test, which compares sample means on an ordinal basis.

The results of the ANOVA tests for the dwelling density data adhere to the expectation. The cells in the first two classes near the streetcar do not exhibit significant changes in the mean values over time, while the null hypothesis that there is no difference in the means is rejected in the third and fourth class of cells. The 
street connectivity data yield slightly different results, with cells in the third class also showing no significant change. This is true using both the parametric and nonparametric tests. Figure 34 displays these results graphically; I use the descriptive statistics for shading when the relationships between groups were not included in the tests.

A more sensitive measure of temporal changes is accomplished by comparing sequential pairs within the spatial groupings. The parametric tests I used are Matched Pair T-tests; the nonparametric equivalent used on the connectivity data is the Wilcoxon Signed-Ranks test. An advantage of the parametric matched pairs test is the ability to estimate the difference in means. This will allow us to place a value on the rate of change indicated by our sampled values. Of course, this is not possible using the nonparametric test, which only considers data on the ordinal level.

The numbers in the Figure 35 are rounded to the nearest half. The results of these tests on the dwelling data show that the areas near the streetcar lines were still growing at a good clip between 1925 and 1936, then display a marked slowdown. While some of this may be a result of the Depression, it is clear that the areas farther from the streetcar lines are still growing between 1936 and 1945. A more likely explanation of the slowdown near the streetcar lines is that these areas had become saturated; they had reached the acceptable density limit, and people were taking advantage of the accessibility of more land. The connectivity data does not have a similar drop-off, but does show faster rates of growth in the areas farther from the streetcar lines. Recall that only the class of cells furthest from the streetcars displayed 


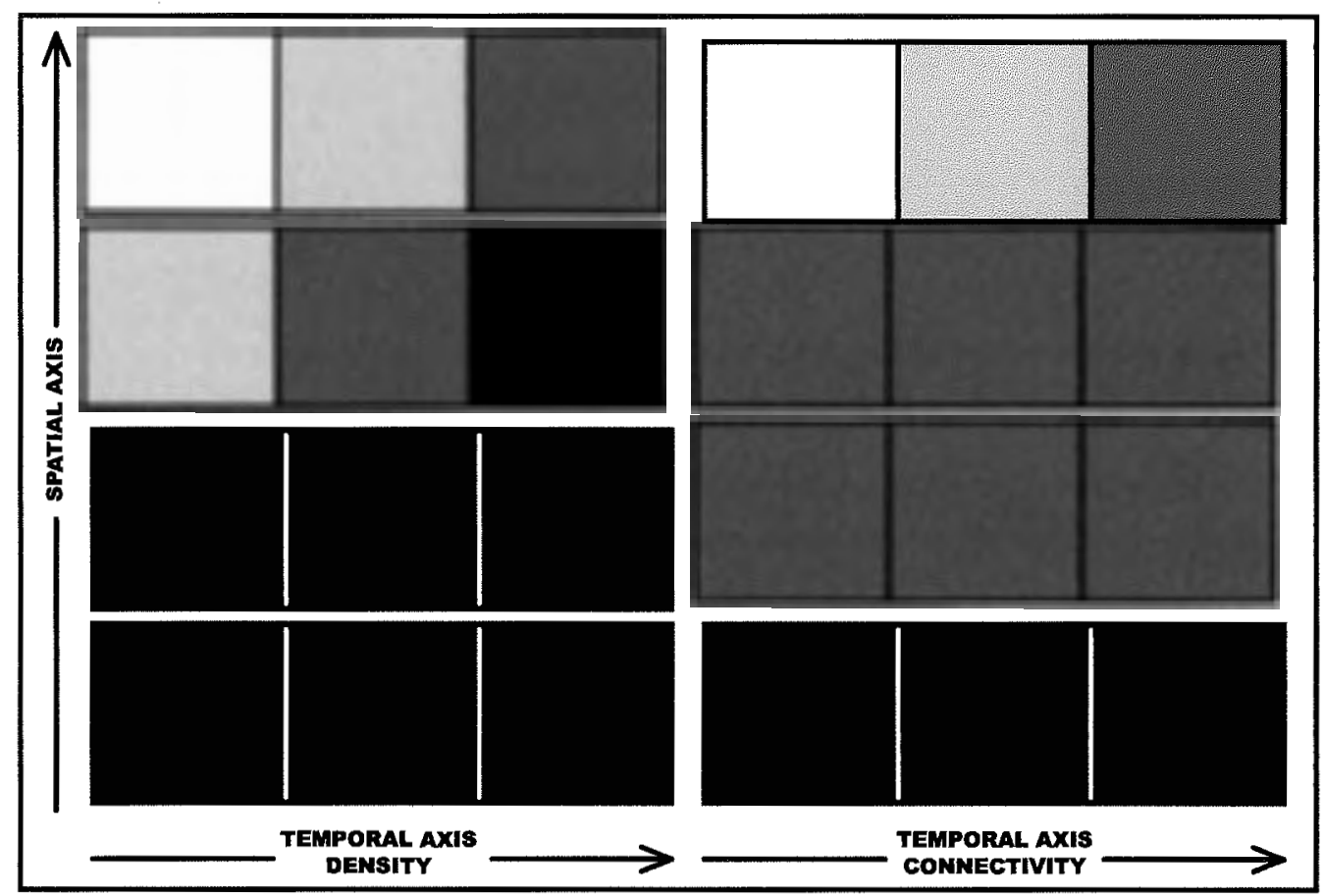

Figure 34: ANOVA/Kruskal-Wallis Results

Parametric tests suggest, as was expected, that dwelling unit density does not significantly change in the areas near the streetcar. Both the parametric and non-parametric tests yield the same results for the street network connectivity measures: only those cells furthest from the streetcar lines change significantly over time. 


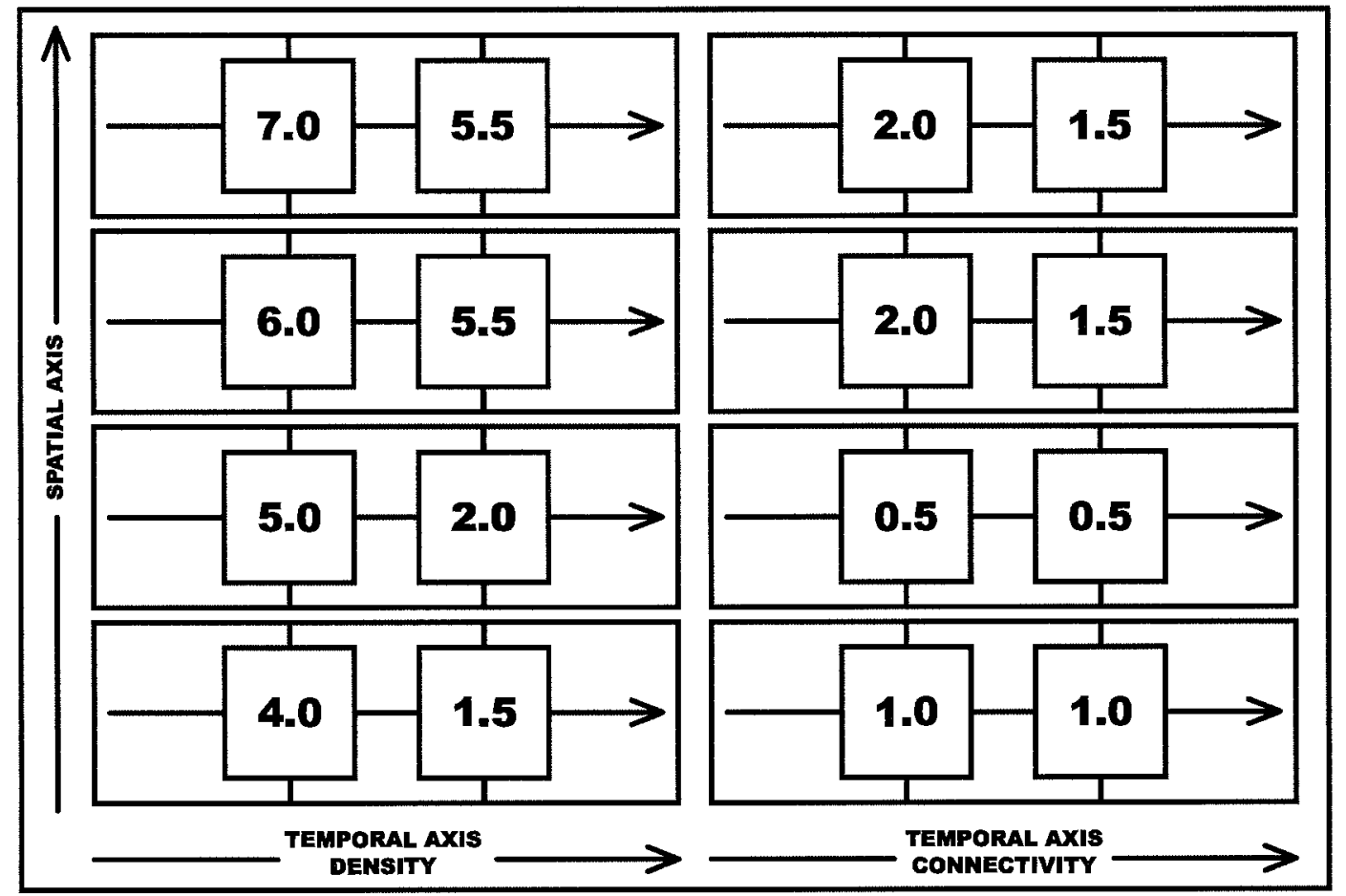

Figure 35: Matched Pairs Estimates of Difference in Means Matched Pairs tests allow for an estimation of the difference in population means. The dwelling density data slows down rapidly near the streetcar line after 1936, while the highest rates of growth occur in the land made accessible by the automobile. The street connectivity variable has a similar pattern; less can be inferred from these results because these data are not normally distributed. 
significant change in the comparisons of three means and medians for the connectivity data.

Because the connectivity data is not from a normal distribution, less may be inferred from these estimates. The nonparametric Wilcoxon tests for these data conform exactly to what is expected: no significant changes in the two groups of cells closest to the streetcars; for the cells in the second class this is true even when comparing the data over the entire twenty year period. Significant changes are indicated in the areas farther from the streetcars for every advance along the temporal axis. I have incorporated these results in the Figure 36, keeping in mind the results of the previous tests. For example, in the third spatial class of connectivity data, I have incorporated the changes indicated by the paired samples tests but kept the range low, reflecting the results of the ANOVA and Kruskal-Wallis tests.

To this point I have been comparing data along the temporal axis; these data have been collected from the same cells for different years. Now I will consider data along the spatial axis. Since these data come from different sample cells, Independent Samples tests are used. The nonparametric equivalent used on the connectivity data is the Mann-Whitney test. A multitude of comparisons are being made; the patterns are more clearly communicated by grouping the spatial classes, from four groups to two. I grouped together the two classes of cells nearest to the streetcar lines, and the two classes of cells furthest from the streetcar lines were combined into the second group. For the dwelling data, all comparisons between the spatial groups for each year result in a rejection of the null hypothesis. However, the tests suggest that the areas 


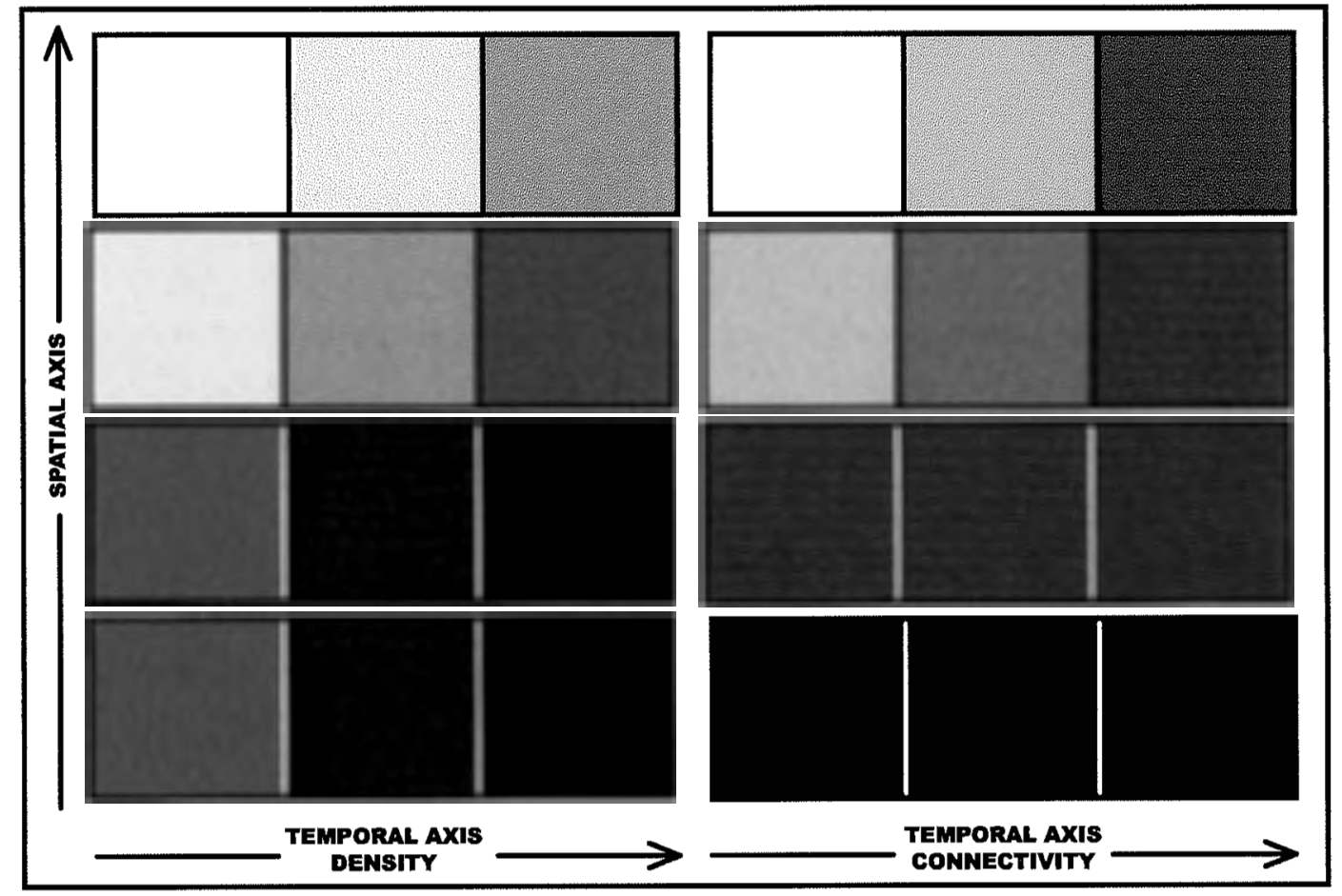

Figure 36: Paired Samples Test Results The results of the matched pairs tests are incorporated into the model. The dwelling density variable is still increasing at a high rate near the streetcar until 1936, before it slows considerably. The more distant areas grow throughout the entire time frame. The street connectivity data is more static; little changes near the streetcar line, but the rates of change increase with greater distance from the streetcar line. 
far from the streetcars had, by 1945, achieved densities similar to those near the streetcar in 1925. The connectivity data reveal less complex patterns: the automobile development of 1945 has connectivity measures not significantly different than the streetcar development for any year.

Significant differences exist, however, between the spatial groups in 1925 and 1936. Parametric and Non-parametric tests produce the same results, which are illustrated in Figure 37. The patterns closely follow that already established by the previous tests: the connectivity data adhere more closely to the expected model, while the dwelling density data display more shifting in the lower spatial classes than expected.

My sampling methodology was designed to select cells evenly distributed among the four classes of distance to the streetcar lines, and also spread along the extent measuring distance to the downtown area, identified as the location of City Hall. Even though the hypothesis of this paper concerns the influence of transportation on patterns of land use, since much of the background material identifies proximity to downtown as a factor in shaping patterns of urban growth, it makes sense to spend some time examining the distribution of the variable values in relation to this attribute of the sample cells.

The values of this attribute ranged from 1 to 50 for the sampling frame; selected cells had values ranging from 5 to 46 . I grouped these data from 5-21 and from 22-46 for comparison. This is an approximation of a quantile classification, with an equal number of cases in each class. In this case, 62 of the 120 sample cells fell 


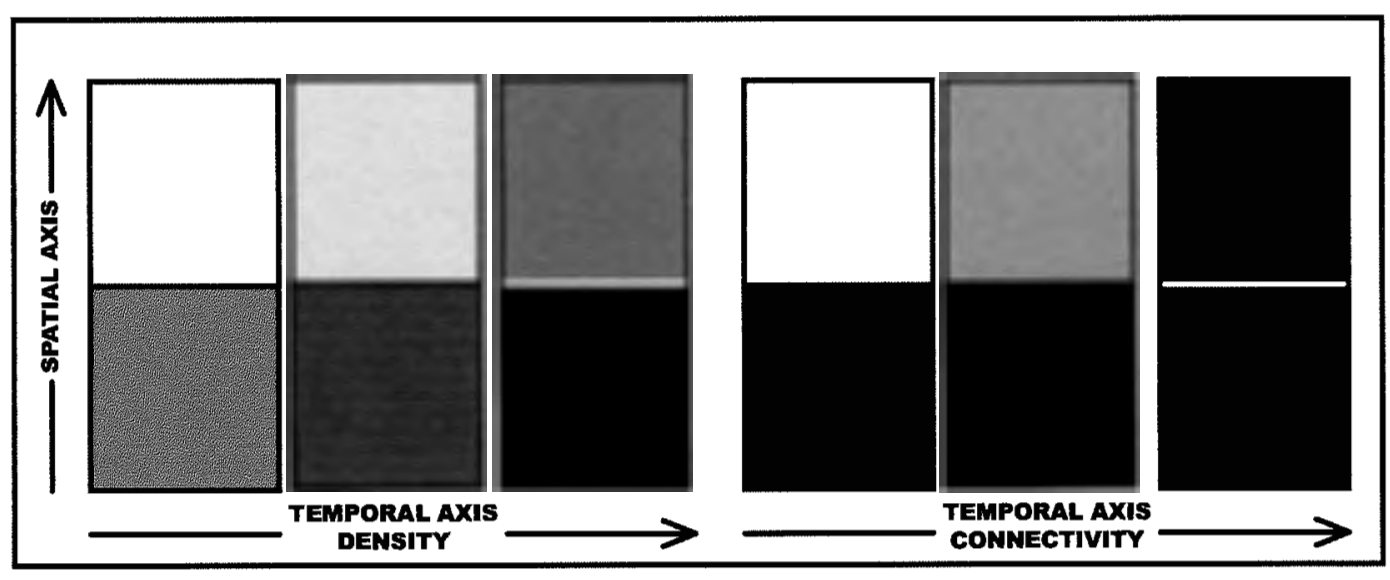

Figure 37: Independent Samples Test Results Spatial classes 1 and 2 are grouped together, as are classes 3 and 4 , for the sake of clarity. The dwelling density data is once again more in flux. Distance to the streetcar always results in significant differences between the groups, but by 1945 the areas further out had achieved densities similar to what those closer to the streetcar lines had in 1925. Tests on the street connectivity data do suggest that by 1945 the locations of the streetcar lines had little effect on this variable. 
into the group closest to City Hall. Cells in the original sampling frame that could have been selected and put into the first class ranged from about 1.25 to 3.75 miles from City Hall, with the second class covering an area that extended over 7 miles from downtown. The descriptive statistics that result are shown in Figure 38.

The ANOVA/Kruskal-Wallis results rejected the null hypothesis in every case except the comparisons between the connectivity data closer to downtown. Paired Samples/ Wilcoxon tests on the connectivity data, however, suggested significant differences for each increase along the temporal axis, for virtually every comparison, though at a faster rate in the more distant parts of the city. Connectivity grew steadily between 1925 and 1945 at a remarkably consistent rate $(0.5$ for each period near downtown, 2.0-2.5 farther out). The independent samples tests reject every comparison based on distance to City Hall for any year, except for the nonparametric test on the connectivity data in 1945 . This last result suggests that by this later date the outlying areas were approaching the closer-in part of the city in terms of this variable. In both the case of the dwelling density and street connectivity data, however, no significant differences were detected between those cells close to downtown in 1925 and those far from downtown in 1945, meaning that the city had developed in the outlying areas by 1945 to about the same degree as had existed closer to downtown twenty years earlier.

The rate of change for the density data is exactly equal between the classes over the twenty year period, though there is a shift near the midpoint. Before 1936, the areas closer to downtown grow more quickly in terms of density; after 1936 


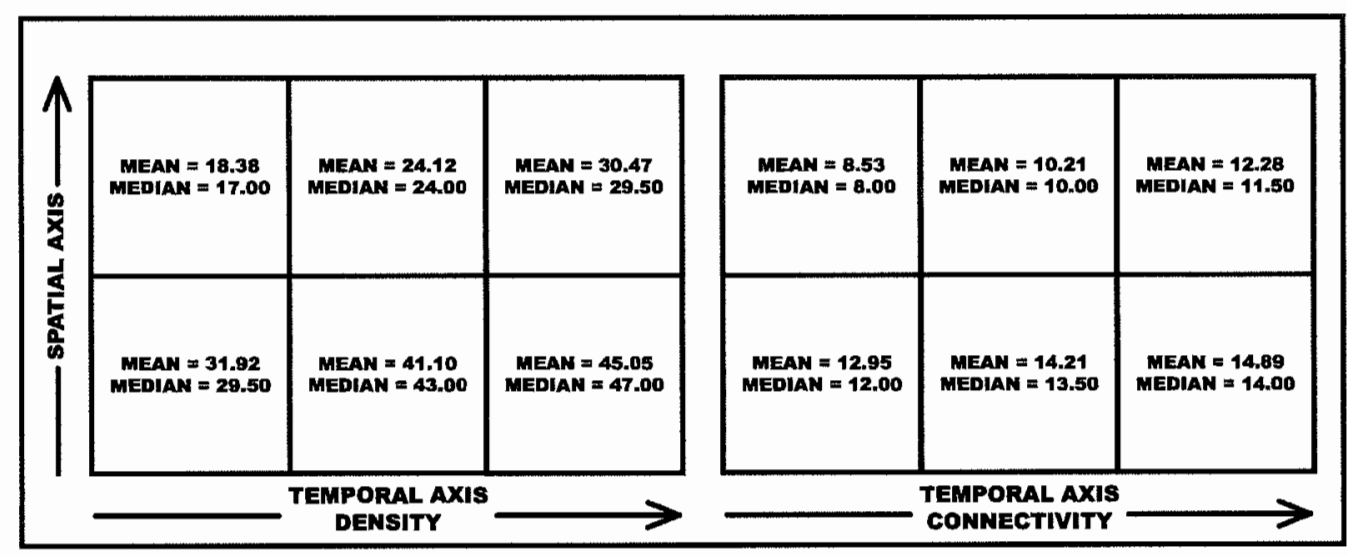

Figure 38: Descriptive Statistics in Relation to Distance to City Hall Little in these values suggests a pattern other than steady outward growth. Areas closer to the urban core tend to have higher measures of the variables, but in both spatial classes, continuous growth exists throughout the study period. 
that situation is reversed. While the variables are higher closer to City Hall, I did not find that density had been established at an early date, as I did when considering the influence of the streetcar. As before, the connectivity data displays more structure, as it appears the influence of distance to downtown is actually quite similar to that of proximity to the streetcar lines. I have summarized the results of all the tests in Figure 39. 


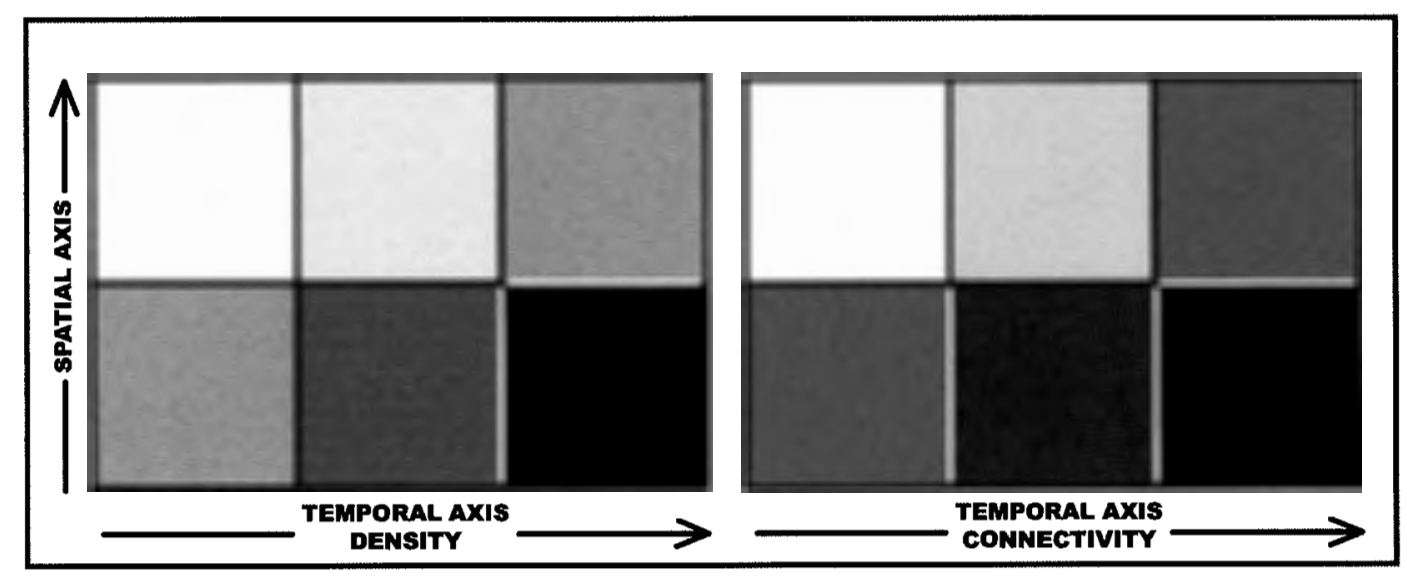

Figure 39: Summary of Test Results in Relation

to Distance from City Hall

Inferential tests do not offer any information not contained in the descriptive statistics. The density data indicates nothing more than a city growing steadily outward. The connectivity data shows more similarities to the patterns that existed in relation to the streetcar. The street network shows little growth in those areas closer to the downtown core. 


\section{Chapter 6: Discussion}

Given the results of the inferential tests, in this section I will assess my model of expected values as seen in Figure 31, and by extension the urban models and New Urbanist ideas about urban growth on which it was based. Speaking generally, the tests confirmed the patterns I expected to see. The variables I measured are much more static close to the streetcar lines, and change at a greater rate in the areas not accessible by these fixed transit routes. The second idea important to the model is that the growth taking place in those newly accessible areas takes on a different form, and that the variables that I consider are good measures of that form. Even as these areas develop, they never attain the same level of dwelling density and street connectivity as had existed close by the streetcars. That idea is best supported by the test statistics of the independent samples tests, which decrease with each year; in fact the comparison of connectivity measures results in the null not being rejected by 1945 .

The results of the tests performed on the street connectivity data more closely adhere to the expected pattern. It does appear that the areas closer to the streetcar lines had an established form by 1925 that did not significantly change over the following twenty years. The sample cells that actually intersected the streetcar line had the highest connectivity measures, while cells in the second of the four spatial classes had lower mean and median values but still remained constant over the temporal span of the study. The changes over time occurred in the last two classes of sample cells, which increased significantly in the level of connectivity after 1925 . The Wilcoxon tests do not detect significant differences in the two classes of cells near the streetcar 
even over the entire twenty year period, but in the third and fourth class along the spatial axis, significant changes occur in every comparison.

The data for dwelling unit density showed slightly different tendencies. While the two classes of cells near the streetcar lines did not display differences significant enough to register when comparing the means for all three years, the paired samples tests reveal change in these areas, but at a slower rate compared to the cells more distant from the streetcar lines, which continued at the same approximate rate-always higher than that near the streetcars- for the entire study period. This becomes especially true after 1936, when building near the streetcar lines slows nearly to a standstill, averaging only 1.5-2 buildings per ten acres. While the country's economic situation no doubt played some role, rapid growth continued in those parts of the city now accessible by automobile. A comparison of the rates of growth is valid because of the normal distribution of these data, allowing parametric tests which can consider the measurements on an interval-ratio level.

Why the difference in results between the two variables? A significant correlation does exist, so there is a relationship; the correlation is weak, so there are differences in how these variables change over time. In 1925, both variables are positively skewed (though the Kolmogorov-Smimov test accepts the dwelling unit data as normal), and their correlation is high. In the streetcar era, people needed to live in a highly connected street network; they walked to the streetcar lines, and would not be willing to travel far out of their way by foot. Some parts of the city, those distant from the dense development near the streetcar lines, were nearly empty. These 
very low values pull the mean value down and cause the skew. While the connectivity data stays remarkably consistent in its skewness, this same measure for the dwelling density data shows a marked decrease with time. Certainly, with the automobile the need to live within an efficiently circulating street system was decreased, as people were driving directly to their homes, and going a little out of the way was less inconvenient. People could build homes in locations based on other priorities.

One possible cause for the continued skewness of the connectivity data, even while the independent samples tests are showing it evening out based on both distance to the streetcar and distance to downtown by 1945 , is the larger spatial scale of the street network compared to dwellings. The street network has at least 200 feet between intersections, while the typical tax lot measures about 50 by 100 feet. A sample cell would capture data for dwellings within a moderately developed area, but could fail to do the same for the street network were several intersections to fall just outside the boundary of the cell. This could happen with any cell size. The overall values of the measures are lower for the connectivity data, and there are a few that have zero values even in 1945.

The connectivity, measuring the level of development of the street network, and the dwelling unit density, measuring the level of development of residential building, operate at different scales temporally as well. The street needs to exist before the building can be built. The transportation network, compared to dwellings, is also more consciously planned and directed. Alexander's (1987) lament that cities lack the vision of a single artist is less the case with the street network, built by the city 
itself, than with housing, with homebuilders and homeowners all involved; therefore, the response to new influences could be quicker. One interpretation of the data in this study is that dwelling densities lagged behind the establishment of a connected street network; the street network had been completed by 1925 but attainment of correlating density levels is not apparent in the aerial photography until 1936. This interpretation would also explain the evening out of the connectivity measures, shown by the independent samples tests, by 1945 . This idea makes sense; the hypothesis of this study, after all, is that transportation change drives changes in land use patterns, so those land use patterns should be reflected first in the transportation system.

Extending the temporal extent of the study would likely not reveal dwelling unit densities in the areas far from the streetcars ever attaining high levels. With the advent of the freeway era, more land on the urban edge served to relieve the pressure. The argument that downtown Portland remains the dominant destination of travel is more difficult to make after 1945 , with the absorption of suburban centers into the urban system. It is interesting to note that today, with an urban growth boundary in place, many close-in Portland neighborhoods are experiencing infill of vacant lots, while the developed areas along the edge of the urban growth boundary show a distinct edge much like that seen in the 1925 aerial photography. An artificial reining in of growth was unnecessary when transportation technology was not conducive to sprawl.

The variables studied here exhibit spatial patterns that concur with some aspect of virtually all the urban models. The steady outward growth from the urban center 
supports ideas contained within the Burgess model; while I have considered no explicitly socioeconomic measures as Burgess did, outward expansion of development does conform to the situation Burgess described. The influence of the streetcar on the location and type of urban development supports axial models such as Hoyt's. Clearly the outward growth was directed by the fixed transit lines, and was not evenly distributed in concentric patterns.

The most difficult model to assess is the model of Harris and Ullman because it provides such a vague basis for the theorized locations of land use types; however, the evening out of the transportation network apparent by 1945 would allow the location of land uses to be based on the criteria presented in the multiple-nuclei model, rather than constrained by access. The fact that patterns based on socioeconomic factors are found also in the built environment, buildings and streets, lends credence to Green and Monier's socio-physical connection, as well as Adams' assertion that the built environment must be considered to understand urban dynamics.

Adams' model, or rather that part of it that examines the transition from electric streetcar to early automobile use, is the single best descriptor of the patterns I found. Like Adams, I found that while distance from the center remains a factor in the location of urban growth, predictable deviations from the concentric patterns are associated with fixed transportation routes, and that these deviations are reflected in the built environment. However, Adams used housing age based on census data when examining his transects of Minneapolis; those data reveal when an area was built, but not how. The correlation between housing density and housing age is discussed 
throughout his paper (Adams, 1970), so perhaps Adams feels that age implies certain density levels. In presenting his results Adams does include the number of dwelling units within census tracts along the transect, but the varying sizes of those tracts make this number impossible to interpret. Adams includes the statement "Housing density per unit area is ignored" (Adams, 1970, 60). My results add this element to Adam's model. This is a good illustration of the advantage of a data source like aerial photography, which is not limited to delineations designed for some other purpose.

How pre-automobile urban land use differs from automobile development is of great concern to the New Urbanists in supporting their conception of the evolving city. Calthorpe's TOD designs, with their clustering of dense housing in proximity to transit, are similar to the pre-automobile land use patterns apparent in the 1925 aerial photography. TODs are designed around the point location of a transit node rather than spread along the extent of a transit line, so Calthorpe's circular pattern is elongated into fingerlike extensions radiating out from the city. With the automobile came lower density housing in the remaining area, the situation Calthorpe is attempting to avoid by using TOD.

Southworth's ideas about the evolution of the street are also supported by these results, though over a much shorter time span. Even over a period of only twenty years -albeit an important twenty years, given the shift in transportation usagesignificant differences in connectivity are apparent between the established, developed urban form and that which occurred during the nascent automobile era. Southworth was concerned with development along the urban edge; the parts of the city I examine 
were the urban edge for this particular era. To fully assess Southworth's ideas, the study area would need to constantly shift farther from the urban core.

Boarnet and Crane (2001) criticized New Urbanist designs on the basis that they could be just as easily result in many short automobile trips as increased pedestrian activity unless precautions are taken. One approach they discuss is to design for pedestrian connectivity separate from, or additional to, the automobile street network, such as that implemented in Duany's plan of Seaside in Florida (Boarnet and Crane, 2001), also integral to Calthorpe's (1993) ideas. In examining the 1925 aerial photography I chose not to incorporate elements of the transportation network that were not part of a built system, but which were clearly used: a secondary network that appears pedestrian created and utilized. These appear largely on the urban periphery, such as the example in Figure 40, or in a developed area crisscrossing an empty block, and have been obliterated by 1936. An interesting study would compare modern designs incorporating pedestrian connectivity to these networks examined on a smaller, localized scale. This approach would include elements of the street network that were not the result of some larger scale planning. 


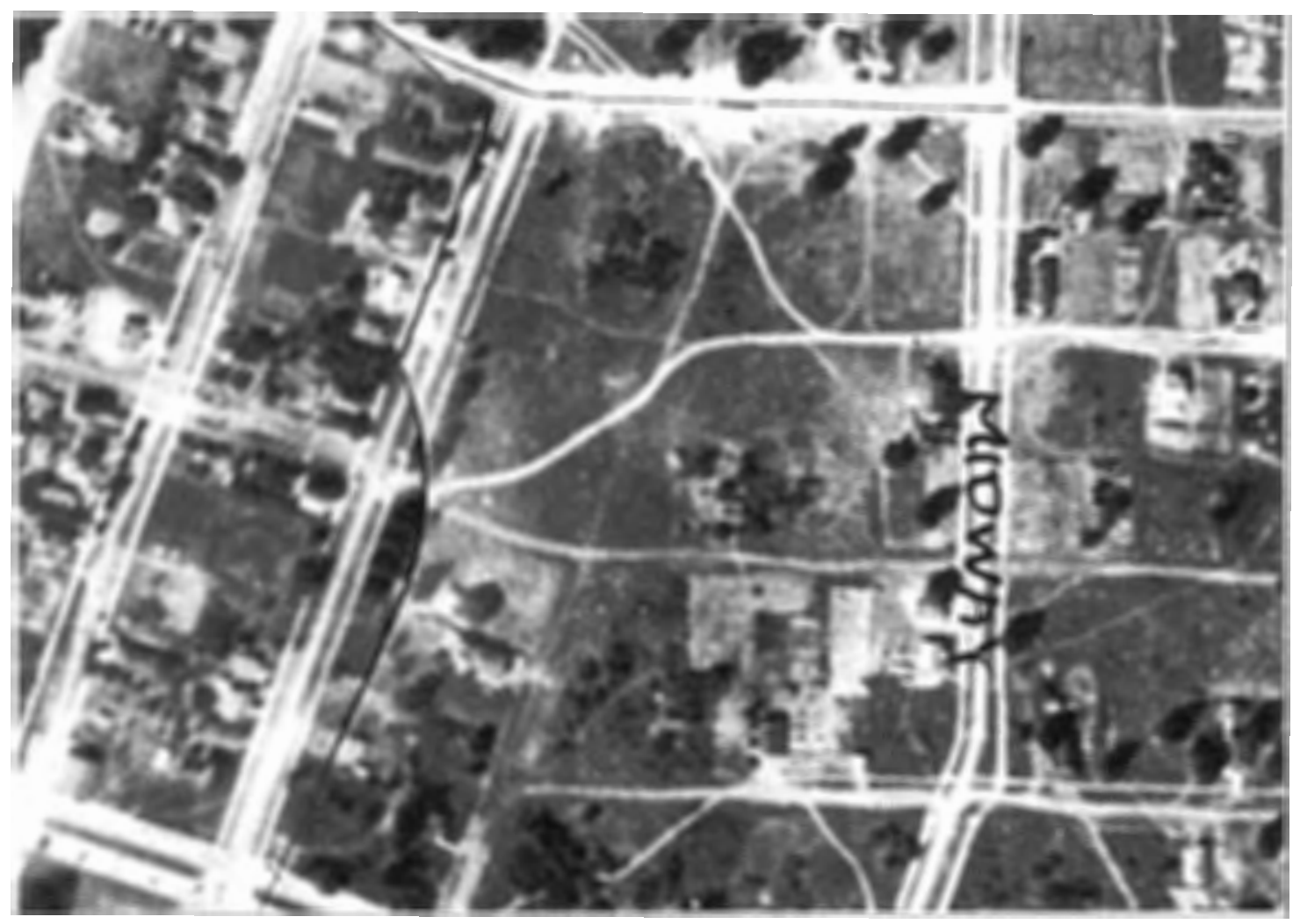

Figure 40: Pedestrian Network in 1925 Aerial Photography The area shown in this aerial photograph is on the urban edge. The established street network is not fully developed, but the presence of several paths demonstrates that not all transportation networks are streets. (Original photograph in the Collection of the Stanley Parr Archives and Records Center) 


\section{Chapter 7: Conclusion}

The hypothesis of this paper is that a change in transportation usage brought with it a change in patterns of land use; specifically, that the advent of the automobile lowered levels of housing density and street network connectivity in comparison to previously built parts of the city. Areas that were developed along the fixed routes of the streetcars display one type of development, while those areas left vacant but which were filled in as they later became accessible display an identifiably different pattern of development. My focus was on the neighborhood areas close to the downtown core, within the radius of the trolleys' reach, not those parts of the city reached during the freeway era. My interest is in the difference between and juxtaposition of the two types of growth.

Models such as those of Burgess, Hoyt, Harris and Ullman, and Adams appear static. The edges are drawn in black lines: on this side we have one type of urban form, on the other side we have another. The plans of the New Urbanists similarly represent a generalization of what is on the ground. While in fact urban growth occurs against the backdrop of constant change, a model can serve as a descriptive device to help in understanding the processes that shape a city, always keeping in mind that it is a simplification.

In most quantitative studies, rejection of the null hypothesis is of interest. Until evidence is provided to the contrary, the assumption is made that things are similar. When things are not similar — when the null is rejected — some outside influence is assumed, and conjecture as to what may contribute to that dissimilarity is 
offered. In this study that situation is reversed. We have an expectation that a city grows, over time and over space. We expect change. When change does not take place, that is the case where something is of interest.

These statistical tests do not establish absolute equivalence between those areas for which the null hypothesis is not rejected; all that can be stated for sure is that the differences are not so great that sampling error cannot be discounted as the cause. Conversely, when the null hypothesis is rejected, to conclude that a difference exists between the means or medians of the entire population is incorrect; rather I cannot state for certain that these measures are identical. I expected, and indeed got, several contradictory results. I have tried not to over-interpret, or place too much importance on the results of any one particular test. My hope was that a discernible pattern would emerge, and I believe that one did.

As demonstrated by the comparisons of the three neighborhoods, this pattern was not entirely dependent on socioeconomic factors, but occurred in all types of areas. By taking a random sampling of areas that did not have some exclusionary factor, land set aside for parks or industrial use for example, or topographic variation that causes a whole different set of circumstances, I have attempted to demonstrate that transportation was the cause of the shape the city adopted. The patterns that do emerge can be applied to the whole study area, and those patterns were a result of the transportation system.

The parts of the city that were built along streetcar lines did not change very much between 1925 and 1945 because they were intensively developed early in the 
study period. The reason was access. The streetcar lines defined the path of least resistance, in terms of time and effort, in traveling from the residential areas of Portland's eastside to the central business district. These areas projected out from the city center, disrupting a simple concentric pattern of overall growth, a situation first noted by McKenzie (1933) and Hoyt (1939). When the automobile came along, more land was made accessible, and those areas did change over the study period.

The way these newer neighborhoods grew was different than what had come before. The very meaning of the word automobile implies a release of constraints; the individual moves himself or herself. Lot sizes and street widths increased in part just to accommodate the bulk of these machines; even architectural design changed as garages became more prominent (Southworth, 1993). The car got its own little house, and front porches disappeared. There is a barren appearance to some of these neighborhoods, reminiscent of the FHA regulation, cited earlier, discouraging street planting. My personal sense is that of a much lower level of detail, which I ascribe to the fact that the majority of people passing through the neighborhood do so by car. The speed of automobile travel blurs the surroundings and creates what Southworth refers to as "indifference to landscape" $(1993,285)$. The circulation patterns of the streets also have a different feel; streets in these neighborhoods may often be pleasant to walk through, but not if you are trying to get somewhere. They were not meant for that.

My interest in this topic began with a familiarity with what is on the ground. I sensed the pattern before I understood the cause. The variables I examined, housing 
density and street network connectivity, I chose for several reasons: they affect the sense of place, are important to modern planning concerns, are quantifiable, are linked to the socioeconomic variables of the classic urban models, and are visible in aerial photography. Other elements, such as architectural styles, the presence of sidewalks, or the extent of tree cover, are distinguishing characteristics of different neighborhood types within the study area.

Today it seems a common assumption that people drive where they need to go. Traffic congestion, lack of downtown parking, and air pollution are among the problems associated with this type of transportation. These are tangible issues, unrelated to the subjective criticisms already discussed. The construction of alternative transit options is met with a certain disdain, yet few major American cities were born during the automobile age. The goals of the New Urbanist movement are laudable, but so often they seem to be making the same assumptions as other developers, just offering a different spin in an effort to package a product marketable to a particular segment of society. The land use patterns the New Urbanists copy already exist in the older neighborhoods and streetcar suburbs. It is curious that these areas, which offer many of the same qualities, do not seem to receive the same level of attention.

Since the automobile is not going to disappear, future residential urban growth needs to accommodate those who chose that option. To mitigate the impact, many feel that it is important to allow for and promote other options. Whether replication of earlier land use patterns is an effective way to accomplish this goal is a different argument than has been made here. Historical studies aid in understanding the 
dynamics that shape an urban area; how the multitude of actors respond to change and how those reactions affect the urban landscape. An understanding of past processes how we got to where we are - is an important tool in getting to where we want to be. 


\section{REFERENCES}

Abbott, C. 1983. Portland: Planning, Politics and Growth in a Twentieth-Century City. Lincoln: University of Nebraska Press.

Adams, J. S. 1970. Residential Structure of Midwestern Cities. The Annals of the Association of American Geographer. 60 (1): 37-62

Alexander, C., Ishikawa, S., and Silverstein, M. 1977. A Pattern Language: TownsBuildings-Construction. New York: Oxford University Press.

Alexander, C., Nies, H., Anninou, A. and King, I. 1987. A New Theory of Urban Design. New York: Oxford University Press.

Banai, R. 1998. The New Urbanism: An Assessment of the Core Commercial Areas, with Perspectives from (Retail) Location and Land-Use Theories, and the Conventional Wisdom. Environment and Planning B-Planning and Design 25: 169-185.

Bianco, M. J. 1994. Private Profit versus Public Service: Competing Demands in Urban Transportation History and Policy, Portland, Oregon, 1872-1970. Dissertation: Portland State University. Ph.D. Program in Urban Studies.

Boarnet, M. G. and Crane, R. 2001. Travel By Design: The Influence of Urban Form on Travel. New York: Oxford University Press.

Borchert, J. 1967. American Metropolitan Evolution. Geographical Review. 57: 301 322

Branch, M. C. 1948, reprinted 1971. City Planning and Aerial Information. Cambridge, MA: Harvard University Press.

Burgess, E. W. 1929. Urban Areas. In Chicago: An Experiment in Social Science Research. 113-138. Chicago: The University of Chicago Press.

Burt, J.E. and Barber, G.M. 1996. Elementary Statistics for Geographers, Second Edition. New York. The Guilford Press.

Calthorpe, P. 1993. The Next American Metropolis: Ecology, Community and the American Dream. New York: Princeton Architectural Press.

Calthorpe, P. and Fulton, W. 2001. The Regional City. Washington, DC: Island Press.

City of Portland Bureau of Planning. 2002. Portsmouth Neighborhood Plan. 
Congress for the New Urbanism. 2000. Charter of the New Urbanism. New York: McGraw-Hill.

Department of Transportation Federal Highway Administration and Oregon State Highway Division.1973. Environmental Impact Statement Administrative Action for Marquam Bridge-Interstate 205 Section Interstate $80 \mathrm{~N}$ and Interstate 205- $122^{\text {nd }}$ Avenue Section Primary Route 24, Portland, Oregon Multnomah County.

Duany, A., Plater-Zyberk, E. and Speck, J. 2000. Suburban Nation: The Rise of Sprawl and the Decline of the American Dream. New York: North Point Press.

Eliel, L. T. 1959. One Hundred Years of Photogrammetry. Photogrammetric Engineering 25 (3): 359-363.

Green, Lt. Col. N. E. 1957a. Aerial Photographic Interpretation and the Social Structure of the City. Photogrammetric Engineering 23 (1): 89-96.

Green, Lt. Col. N.E. 1957b. Comments on Mr. Witenstein's Review of, "Aerial Photographic Interpretation and the Social Structure of the City." Photogrammetric Engineering 23 (1): 99.

Green, Lt. Col. N. E. and Monier, Capt. R. B. 1959. Aerial Photographic Interpretation and the Human Ecology of the City. Photogrammetric Engineering 25 (5): 770-773.

Harris, C. D. and Ullman, E. L. 1945. The Nature of Cities. The Annals of the American Academy of Political and Social Science 242: 7-17.

Howlett, B. E. 1963. Determining Urban Growth and Change from Aerial Photograph Comparisons. Highway Research Record. (19): 1-16.

Hoyt, H. 1939. The Structure and Growth of Residential Neighborhoods in American Cities. Washington, DC: United States Government Printing Office.

Jackson, K. 1985. Crabgrass Frontier: The Suburbanization of the United States. New York: Oxford University Press.

Kansky, K.J. 1963. Structure of Transportation Networks: Relationships Between Network Geometry and Regional Characteristics. Chicago: University of Chicago Research Paper No. 84. 
Krizek, K. J. Under Review. Neighborhood Services, Trip Purpose, and Tour-Based Travel. Transportation.

Krizek, K. J. Forthcoming. Operationalizing Neighborhood accessibility for Land Use- Travel Behavior Research and Regional Modeling. Journal of Planning Education and Research.

Labbe, J. T. 1982. Fares, Please! Those Portland Trolley Years. Caldwell, Idaho: The Caxton Printers, Ltd.

Lynch, K. 1960. The Image of the City. Cambridge, MA: The MIT Press.

MacColl, E. K. 1976. The Shaping of a City: Business and Politics in Portland, Oregon 1885-1915. Portland, OR: The Georgian Press.

MacColl, E. K. 1979. The Growth of a City: Power and Politics in Portland, Oregon 1915 to 1950. Portland, OR: The Georgian Press.

Marshall, A. 2000. How Cities Work: Suburbs, Sprawl and the Roads Not Taken. Austin: University of Texas Press.

McKenzie, R.D. 1933, republished 1967. The Metropolitan Community. New York: Russell \& Russell.

Meyer, W. B. 1994. Bringing Hypsography Back In: Altitude and Residence in American Cities. Urban Geography 15 (6): 505-512.

Meyer, W. B. 2000. The Other Burgess Model. Urban Geography 21 (3): 261-270.

Monier, Capt. R. B. and Green, Lt.Col. N. E. 1957. Aerial Photographic Interpretation and the Human Geography of the City. The Professional Geographer 9 (5): 25 .

Muller, P. O. 1981. Contemporary Suburban America. Englewood Cliffs, NJ: Prentice-Hall, Inc.

Park, R. E., Burgess, E. W., and McKenzie, R. D. 1925, reprinted 1967. The Growth of the City. In The City. 47-62. Chicago: The University of Chicago Press.

Richter, D. M. 1969. Sequential Urban Change. Photogrammetric Engineering 35 (8): 764-770.

Rogerson, P. A. 2001. Statistical Methods in Geography. London: Sage Publications. 
Scargill, D.I. 1979. The Form of Cities. New York: St Martin's Press.

Southworth, M. and Owens, P. M. 1993. The Evolving Metropolis: Studies of Community, Neighborhood, and Street Form at the Urban Edge. Journal of the American Planning Association 59 (3): 271-287.

Southworth, M. and Ben-Joseph, E. 1997. Streets and the Shaping of Towns and Cities. New York: McGraw-Hill.

Vance Jr., J. E. 1990. The Continuing City: Urban Morphology in Western Civilization. Baltimore, MD: The Johns Hopkins University Press.

Warner Jr., S. B. 1962, reprinted 1978. Streetcar Suburbs: The Process of Growth in Boston (1870-1900). Cambridge, MA: Harvard University Press.

Witenstein, M. M. 1957. A Review of "Aerial Photographic Interpretation and the Social Structure of the City" by Lt.Col. Norman E. Green. Photogrammetric Engineering 23 (1): 97-98. 


\section{APPENDIX A \\ AERIAL PHOTOGRAPHY ACQUISITION}

1925 Aerial Photography:

Current Location...........Stanley Parr Archives and Records Center, City of Portland Acquired By........................................ Mercer Co., Engineers, Portland

Approximate Scale........................................................... 1:10,000

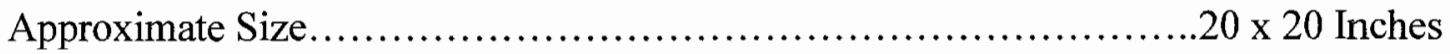

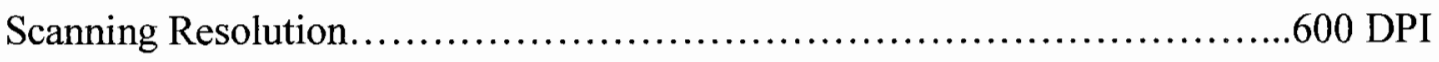

Location of Scanning..................Bureau of Land Management Oregon State Office 1936 Aerial Photography:

Current Location..............................................................University of Oregon Library

Acquired By......................................... Army Corps of Engineers

Approximate Scale ..................................................... 1:15,000

Approximate Size ................................................... 9 x Inches

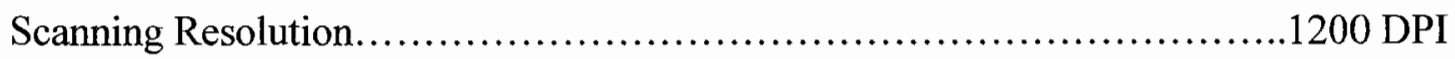

Location of Scanning.....................University of Oregon Map Library GIS Lab 1945 Aerial Photography:

Current Location........................................... Oregon Historical Society Map Collection Acquired By.........................................US Coast and Geodetic Survey

Approximate Scale ................................................... 1: 17,000

Approximate Size.................................................24 x 24 Inches

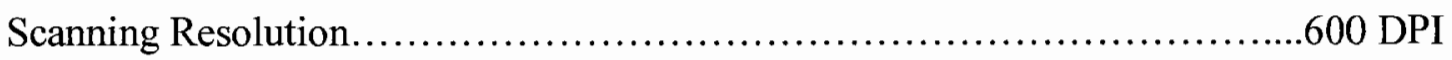

Location of Scanning............... Bureau of Land Management Oregon State Office

All aerial photography was georeferenced to Metro's RLIS dataset using the Image Analysis extension to ESRI's ArcView 3.2 Software. 


\section{APPENDIX B}

\section{CONSTRUCTION OF THE SAMPLE FRAME}

\section{Steps in the Construction of the Sample Grid:}

1. Create grid by overlaying horizontal and vertical lines spaced 660 feet apart

2. Calculate area to ensure cells cover 435,600 square feet

3. Digitize 1927 land use zone map and transform to RLIS projection

4. Query land use zone shapefile for residential areas and create new shapefile

5. Edit residential area shapefile to include narrow strips along streetcar lines

6. Perform union overlay between residential area shapefile and RLIS park data

7. Delete polygons containing parks to create shapefile of study area

8. Select by location cells in grid that have their centers in study area

9. Create new shapefile of sample grid from selected polygons; total cell count equals 1,926

Steps in the Attribution of the Sample Frame:

1. Add unique identifier field for later joining and linking of tables

2. Create fields SCRNK (Streetcar Rank) and CHRNK (City Hall Rank)

3. Select by location cells that intersect streetcar (Portland Department of Transportation CAD file); $\mathrm{SCRNK}=1$

4. Select by location cells within distance of 660 feet of streetcar; SCRNK $=2$

5. Repeat process with increasing 660 foot increments; maximum value $=8$

6. Attribute CHRNK in similar manner to measure distance from City Hall (Metro RLIS data); CHRNK range 10-59

7. Reclass CHRNK to range $1-50$ 


\section{APPENDIX C \\ SPATIAL ATTRIBUTES OF SAMPLE CELLS}

Field Codes:

$\mathrm{ID}=$ Unique identifier for each cell

AREA units are square feet

PERIMETER units are feet

X-CENTROID $=$ Horizontal point location of cell center in RLIS coordinate system

Y- CENTROID $=$ Vertical point location of cell center in RLIS coordinate system

SCRNK $=$ Value of attribute based on proximity to streetcar line

CHRNK $=$ Value of attribute based on proximity to City Hall

\begin{tabular}{|c|c|c|c|c|c|c|}
\hline ID & AREA & PERIMETER & X-CENTROID & Y-CENTROID & SCRNK & CHRNK \\
\hline 14 & 435600 & 2640 & 7627966 & 713028 & 4 & 44 \\
\hline 18 & 435600 & 2640 & 7630606 & 712368 & 4 & 42 \\
\hline 27 & 435600 & 2640 & 7624666 & 712368 & 3 & 46 \\
\hline 33 & 435600 & 2640 & 7629946 & 711708 & 3 & 41 \\
\hline 34 & 435600 & 2640 & 7629286 & 711708 & 2 & 42 \\
\hline 39 & 435600 & 2640 & 7625326 & 711708 & 2 & 44 \\
\hline 42 & 435600 & 2640 & 7623346 & 711708 & 1 & 46 \\
\hline 52 & 435600 & 2640 & 7625986 & 711048 & 1 & 43 \\
\hline 63 & 435600 & 2640 & 7628626 & 710388 & 2 & 40 \\
\hline 75 & 435600 & 2640 & 7633906 & 709728 & 4 & 36 \\
\hline 96 & 435600 & 2640 & 7633906 & 709068 & 4 & 35 \\
\hline 103 & 435600 & 2640 & 7627306 & 709068 & 1 & 39 \\
\hline 136 & 435600 & 2640 & 7631266 & 707748 & 1 & 35 \\
\hline 141 & 435600 & 2640 & 7626646 & 707748 & 3 & 38 \\
\hline 144 & 435600 & 2640 & 7640506 & 707088 & 3 & 30 \\
\hline 155 & 435600 & 2640 & 7631926 & 707088 & 1 & 34 \\
\hline 162 & 435600 & 2640 & 7625986 & 707088 & 4 & 38 \\
\hline 171 & 435600 & 2640 & 7637866 & 706428 & 4 & 30 \\
\hline 174 & 435600 & 2640 & 7635886 & 706428 & 3 & 31 \\
\hline 182 & 435600 & 2640 & 7629946 & 706428 & 3 & 34 \\
\hline 186 & 435600 & 2640 & 7644466 & 705768 & 4 & 28 \\
\hline 203 & 435600 & 2640 & 7629946 & 705768 & 4 & 33 \\
\hline 220 & 435600 & 2640 & 7634566 & 705108 & 1 & 29 \\
\hline 225 & 435600 & 2640 & 7629946 & 705108 & 4 & 32 \\
\hline 234 & 435600 & 2640 & 7641826 & 704448 & 2 & 26 \\
\hline 250 & 435600 & 2640 & 7631266 & 704448 & 4 & 30 \\
\hline 275 & 435600 & 2640 & 7633906 & 703788 & 3 & 28 \\
\hline 277 & 435600 & 2640 & 7632586 & 703788 & 4 & 29 \\
\hline 306 & 435600 & 2640 & 7653046 & 702468 & 2 & 26 \\
\hline 327 & 435600 & 2640 & 7656346 & 701808 & 4 & 27 \\
\hline
\end{tabular}




\begin{tabular}{|c|c|c|c|c|c|c|}
\hline ID & AREA & PERIMETER & $\mathrm{X}$-CENTROID & Y-CENTROID & SCRNK & $\mathrm{CH}$ \\
\hline 344 & 435600 & 2640 & 7655686 & 701148 & 3 & 26 \\
\hline 377 & 435600 & 2640 & 7649746 & 700488 & 3 & 21 \\
\hline 387 & 435600 & 2640 & 7639186 & 700488 & 2 & 21 \\
\hline 396 & 435600 & 2640 & 7651066 & 699828 & 4 & 21 \\
\hline 410 & 435600 & 2640 & 7657666 & 699168 & 4 & 25 \\
\hline 413 & 435600 & 2640 & 7655686 & 699168 & 1 & 23 \\
\hline 416 & 435600 & 2640 & 7653706 & 699168 & 4 & 22 \\
\hline 452 & 435600 & 2640 & 7640506 & 698508 & 2 & 17 \\
\hline 455 & 435600 & 2640 & 7657666 & 697848 & 4 & 24 \\
\hline 463 & 435600 & 2640 & 7652386 & 697848 & 2 & 19 \\
\hline 472 & 435600 & 2640 & 7643806 & 697848 & 2 & 16 \\
\hline 483 & 435600 & 2640 & 7643806 & 697188 & 3 & 15 \\
\hline 487 & 435600 & 2640 & 7657666 & 696528 & 4 & 22 \\
\hline 490 & 435600 & 2640 & 7655686 & 696528 & 2 & 20 \\
\hline 500 & 435600 & 2640 & 7649086 & 696528 & 2 & 15 \\
\hline 519 & 435600 & 2640 & 7652386 & 695868 & 3 & 16 \\
\hline 534 & 435600 & 2640 & 7666246 & 695208 & 4 & 31 \\
\hline 554 & 435600 & 2640 & 7645126 & 695208 & 1 & 12 \\
\hline 572 & 435600 & 2640 & 7652386 & 694548 & 3 & 15 \\
\hline 575 & 435600 & 2640 & 7649746 & 694548 & 3 & 13 \\
\hline 593 & 435600 & 2640 & 7655026 & 693888 & 1 & 16 \\
\hline 595 & 435600 & 2640 & 7653706 & 693888 & 1 & 15 \\
\hline 598 & 435600 & 2640 & 7651726 & 693888 & 2 & 13 \\
\hline 656 & 435600 & 2640 & 7651066 & 692568 & 1 & 11 \\
\hline 681 & 435600 & 2640 & 7655026 & 691908 & 3 & 14 \\
\hline 689 & 435600 & 2640 & 7649746 & 691908 & 3 & 9 \\
\hline 711 & 435600 & 2640 & 7655686 & 691248 & 4 & 14 \\
\hline 732 & 435600 & 2640 & 7661626 & 690588 & 1 & 21 \\
\hline 743 & 435600 & 2640 & 7650406 & 690588 & 2 & 8 \\
\hline 755 & 435600 & 2640 & 7655686 & 689928 & 4 & 13 \\
\hline 845 & 435600 & 2640 & 7661626 & 687288 & 4 & 20 \\
\hline 846 & 435600 & 2640 & 7660966 & 687288 & 4 & 19 \\
\hline 907 & 435600 & 2640 & 7666906 & 685308 & 2 & 27 \\
\hline 909 & 435600 & 2640 & 7665586 & 685308 & 1 & 25 \\
\hline 986 & 435600 & 2640 & 7661626 & 683328 & 4 & 18 \\
\hline 989 & 435600 & 2640 & 7659646 & 683328 & 4 & 15 \\
\hline 1001 & 435600 & 2640 & 7670206 & 682668 & 3 & 31 \\
\hline 1014 & 435600 & 2640 & 7661626 & 682668 & 3 & 18 \\
\hline 1047 & 435600 & 2640 & 7656346 & 682008 & 2 & 10 \\
\hline 1058 & 435600 & 2640 & 7668226 & 681348 & 1 & 28 \\
\hline 1061 & 435600 & 2640 & 7666246 & 681348 & 1 & 25 \\
\hline 1072 & 435600 & 2640 & 7655686 & 681348 & 1 & 9 \\
\hline 1073 & 435600 & 2640 & 7655026 & 681348 & 1 & 8 \\
\hline 1082 & 435600 & 2640 & 7668886 & 680688 & 2 & 29 \\
\hline 1087 & 435600 & 2640 & 7662946 & 680688 & 2 & 20 \\
\hline 1094 & 435600 & 2640 & 7657666 & 680688 & 2 & 12 \\
\hline 1119 & 435600 & 2640 & 7658986 & 680028 & 1 & 14 \\
\hline 1139 & 435600 & 2640 & 7656346 & 679368 & 2 & 10 \\
\hline 1170 & 435600 & 2640 & 7653706 & 678708 & 1 & 7 \\
\hline 1189 & 435600 & 2640 & 7657006 & 678048 & 3 & 12 \\
\hline 1195 & 435600 & 2640 & 7652386 & 678048 & 2 & 5 \\
\hline 1223 & 435600 & 2640 & 7663606 & 676728 & 1 & 22 \\
\hline
\end{tabular}




$\begin{array}{lllllll}\text { ID } & \text { AREA } & \text { PERIMETER } & \text { X-CENTROID Y-CENTROID SCRNK } & \text { CHR } \\ 1275 & 435600 & 2640 & 7662286 & 675408 & 3 & 21 \\ 1278 & 435600 & 2640 & 7659646 & 675408 & 3 & 17 \\ 1284 & 435600 & 2640 & 7655686 & 675408 & 3 & 11 \\ 1294 & 435600 & 2640 & 7666906 & 674748 & 3 & 28 \\ 1302 & 435600 & 2640 & 7660306 & 674748 & 2 & 18 \\ 1303 & 435600 & 2640 & 7659646 & 674748 & 3 & 17 \\ 1316 & 435600 & 2640 & 7666906 & 674088 & 4 & 28 \\ 1366 & 435600 & 2640 & 7666906 & 672768 & 4 & 29 \\ 1417 & 435600 & 2640 & 7662286 & 671448 & 3 & 23 \\ 1439 & 435600 & 2640 & 7666906 & 670788 & 2 & 30 \\ 1458 & 435600 & 2640 & 7651066 & 670788 & 1 & 10 \\ 1470 & 435600 & 2640 & 7661626 & 670128 & 4 & 23 \\ 1477 & 435600 & 2640 & 7656346 & 670128 & 4 & 17 \\ 1486 & 435600 & 2640 & 7671526 & 669468 & 4 & 37 \\ 1511 & 435600 & 2640 & 7673506 & 668808 & 4 & 40 \\ 1537 & 435600 & 2640 & 7673506 & 668148 & 3 & 40 \\ 1552 & 435600 & 2640 & 7660966 & 668148 & 1 & 24 \\ 1583 & 435600 & 2640 & 7660306 & 667488 & 2 & 24 \\ 1615 & 435600 & 2640 & 7656346 & 666828 & 3 & 20 \\ 1669 & 435600 & 2640 & 7652386 & 664848 & 3 & 19 \\ 1672 & 435600 & 2640 & 7649086 & 664848 & 2 & 17 \\ 1683 & 435600 & 2640 & 7655026 & 664188 & 2 & 22 \\ 1688 & 435600 & 2640 & 7649086 & 664188 & 2 & 18 \\ 1712 & 435600 & 2640 & 7650406 & 662868 & 2 & 21 \\ 1725 & 435600 & 2640 & 7651066 & 662208 & 3 & 22 \\ 1729 & 435600 & 2640 & 7651066 & 661548 & 3 & 23 \\ 1774 & 435600 & 2640 & 7645126 & 699828 & 1 & 19 \\ 1790 & 435600 & 2640 & 7650406 & 697188 & 1 & 17 \\ 1792 & 435600 & 2640 & 7641826 & 699828 & 2 & 19 \\ 1800 & 435600 & 2640 & 7643146 & 697848 & 2 & 16 \\ 1806 & 435600 & 2640 & 7645126 & 697848 & 1 & 16 \\ 1851 & 435600 & 2640 & 7655026 & 680028 & 1 & 8 \\ 1854 & 435600 & 2640 & 7653046 & 680028 & 1 & 15 \\ 1865 & 435600 & 2640 & 7658986 & 677388 & 2 & 19 \\ 1874 & 435600 & 2640 & 7658326 & 670788 & 1 & 20 \\ 1875 & 435600 & 2640 & 7658326 & 670128 & 1 & 20 \\ 1877 & 435600 & 2640 & 7658326 & 668808 & 1 & \\ 1897 & 435600 & 2640 & 7651066 & 663528 & 3 & \\ & & & & & & \\ 1\end{array}$




\section{APPENDIX D \\ DENSITY AND CONNECTIVITY MEASURES}

Field Codes:

ID = Unique identifier for each cell

DW25 = Dwelling unit count for 1925

DW36 = Dwelling unit count for 1936

DW45 = Dwelling unit count for 1945

TR25 = Street network connectivity measure for 1925

TR36 = Street network connectivity measure for 1936

TR45 = Street network connectivity measure for 1945

\begin{tabular}{|c|c|c|c|c|c|c|}
\hline ID & DW2 5 & DW36 & DW4 5 & TR25 & TR36 & TR4 5 \\
\hline 14 & 11 & 14 & 28 & 6 & 9 & 20 \\
\hline 18 & 5 & 5 & 22 & 0 & 3 & 10 \\
\hline 27 & 14 & 17 & 30 & 6 & 6 & 9 \\
\hline 33 & 2 & 3 & 12 & 4 & 7 & 14 \\
\hline 34 & 16 & 19 & 24 & 11 & 11 & 7 \\
\hline 39 & 23 & 33 & 27 & 11 & 11 & 11 \\
\hline 42 & 22 & 33 & 30 & 15 & 15 & 15 \\
\hline 52 & 26 & 33 & 44 & 13 & 13 & 18 \\
\hline 63 & 20 & 24 & 27 & 0 & 0 & 0 \\
\hline 75 & 3 & 9 & 13 & 11 & 10 & 14 \\
\hline 96 & 12 & 21 & 24 & 4 & 4 & 7 \\
\hline 103 & 10 & 29 & 37 & 18 & 18 & 21 \\
\hline 136 & 18 & 24 & 33 & 9 & 11 & 11 \\
\hline 141 & 26 & 38 & 41 & 11 & 17 & 17 \\
\hline 144 & 26 & 32 & 31 & 9 & 12 & 16 \\
\hline 155 & 26 & 31 & 31 & 13 & 13 & 10 \\
\hline 162 & 12 & 16 & 14 & 10 & 10 & 11 \\
\hline 171 & 5 & 13 & 29 & 3 & 6 & 13 \\
\hline 174 & 12 & 15 & 32 & 6 & 8 & 11 \\
\hline 182 & 12 & 15 & 23 & 3 & 15 & 23 \\
\hline 186 & 5 & 19 & 25 & 7 & 7 & 7 \\
\hline 203 & 13 & 15 & 22 & 11 & 12 & 12 \\
\hline 220 & 34 & 37 & 43 & 10 & 10 & 10 \\
\hline 225 & 10 & 14 & 20 & 7 & 7 & 7 \\
\hline 234 & 32 & 44 & 48 & 7 & 7 & 7 \\
\hline 250 & 18 & 22 & 29 & 11 & 14 & 15 \\
\hline 275 & 6 & 7 & 42 & 6 & 6 & 16 \\
\hline 277 & 18 & 29 & 32 & 7 & 7 & 7 \\
\hline 306 & 7 & 6 & 1.6 & 0 & 3 & 3 \\
\hline 327 & 5 & 6 & 6 & 3 & 3 & 21 \\
\hline 344 & 10 & 13 & 17 & 9 & 9 & 9 \\
\hline
\end{tabular}




\begin{tabular}{|c|c|c|c|c|c|c|}
\hline ID & DW25 & DW36 & DW4 5 & TR25 & TR36 & TR4 5 \\
\hline 377 & 27 & 37 & 38 & 16 & 16 & 16 \\
\hline 387 & 29 & 40 & 42 & 13 & 13 & 13 \\
\hline 396 & 24 & 31 & 39 & 24 & 24 & 24 \\
\hline 410 & 7 & 12 & 26 & 3 & 4 & 10 \\
\hline 413 & 28 & 39 & 44 & 12 & 12 & 12 \\
\hline 416 & 12 & 26 & 47 & 8 & 8 & 8 \\
\hline 452 & 26 & 42 & 46 & 8 & 8 & 8 \\
\hline 455 & 13 & 22 & 41 & 4 & 11 & 11 \\
\hline 463 & 47 & 51 & 52 & 24 & 24 & 24 \\
\hline 472 & 36 & 47 & 50 & 24 & 24 & 24 \\
\hline 483 & 12 & 39 & 42 & 27 & 27 & 31 \\
\hline 487 & 14 & 19 & 38 & 19 & 23 & 20 \\
\hline 490 & 55 & 62 & 69 & 8 & 8 & 8 \\
\hline 500 & 36 & 38 & 39 & 24 & 24 & 24 \\
\hline 519 & 43 & 53 & 53 & 9 & 9 & 9 \\
\hline 534 & 8 & 9 & 13 & 15 & 15 & 16 \\
\hline 554 & 45 & 46 & 46 & 16 & 16 & 16 \\
\hline 572 & 30 & 43 & 51 & 14 & 14 & 14 \\
\hline 575 & 47 & 53 & 55 & 24 & 24 & 24 \\
\hline 593 & 27 & 31 & 37 & 19 & 19 & 19 \\
\hline 595 & 33 & 39 & 42 & 18 & 18 & 18 \\
\hline 598 & 41 & 51 & 51 & 12 & 12 & 12 \\
\hline 656 & 49 & 55 & 56 & 8 & 8 & 8 \\
\hline 681 & 10 & 54 & 67 & 3 & 9 & 10 \\
\hline 689 & 35 & 53 & 54 & 12 & 12 & 12 \\
\hline 711 & 10 & 50 & 53 & 6 & 23 & 23 \\
\hline 732 & 46 & 46 & 47 & 13 & 13 & 13 \\
\hline 743 & 28 & 39 & 43 & 12 & 12 & 12 \\
\hline 755 & 4 & 44 & 48 & 7 & 11 & 18 \\
\hline 845 & 26 & 45 & 53 & 0 & 16 & 16 \\
\hline 846 & 3 & 39 & 52 & 4 & 21 & 21 \\
\hline 907 & 33 & 36 & 39 & 0 & 6 & 17 \\
\hline 909 & 37 & 38 & 37 & 10 & 16 & 16 \\
\hline 986 & 23 & 30 & 41 & 0 & 0 & 0 \\
\hline 989 & 16 & 49 & 51 & 9 & 9 & 9 \\
\hline 1001 & 20 & 27 & 30 & 8 & 8 & 8 \\
\hline 1014 & 14 & 19 & 27 & 7 & 7 & 10 \\
\hline 1047 & 60 & 67 & 67 & 18 & 18 & 18 \\
\hline 1058 & 39 & 46 & 48 & 8 & 8 & 8 \\
\hline 1061 & 29 & 31 & 34 & 15 & 15 & 16 \\
\hline 1072 & 52 & 51 & 54 & 24 & 24 & 24 \\
\hline 1073 & 48 & 49 & 49 & 24 & 24 & 24 \\
\hline 1082 & 40 & 43 & 39 & 15 & 15 & 15 \\
\hline 1087 & 24 & 28 & 35 & 9 & 9 & 9 \\
\hline 1094 & 55 & 58 & 60 & 20 & 20 & 20 \\
\hline 1119 & 50 & 55 & 55 & 21 & 21 & 29 \\
\hline 1139 & 75 & 75 & 75 & 14 & 14 & 14 \\
\hline 1170 & 35 & 50 & 59 & 16 & 16 & 16 \\
\hline 1189 & 65 & 68 & 68 & 20 & 20 & 20 \\
\hline 1195 & 29 & 44 & 51 & 9 & 9 & 9 \\
\hline 1223 & 19 & 29 & 29 & 7 & 17 & 17 \\
\hline 1275 & 26 & 26 & 40 & 7 & 10 & 7 \\
\hline
\end{tabular}




\begin{tabular}{|c|c|c|c|c|c|}
\hline ID & DW25 & DW36 & DW 45 & TR2 5 & TR36 \\
\hline 1278 & 3 & 3 & 7 & 0 & 0 \\
\hline 1284 & 27 & 40 & 51 & 7 & 8 \\
\hline 1294 & 7 & 10 & 26 & 0 & 0 \\
\hline 1302 & 23 & 27 & 32 & 15 & 15 \\
\hline 1303 & 1 & 3 & 17 & 0 & 6 \\
\hline 1316 & 13 & 20 & 22 & 6 & 12 \\
\hline 1366 & 24 & 19 & 22 & 8 & 8 \\
\hline 1417 & 27 & 36 & 39 & 8 & 8 \\
\hline 1439 & 46 & 49 & 53 & 10 & 10 \\
\hline 1458 & 14 & 14 & 14 & 6 & 6 \\
\hline 1470 & 5 & 14 & 15 & 0 & 7 \\
\hline 1477 & 2 & 1 & 1 & 0 & 6 \\
\hline 1486 & 15 & 24 & 25 & 7 & 7 \\
\hline 1511 & 18 & 22 & 27 & 9 & 16 \\
\hline 1537 & 18 & 26 & 23 & 0 & 0 \\
\hline 1552 & 24 & 26 & 27 & 21 & 24 \\
\hline 1583 & 30 & 33 & 36 & 9 & 6 \\
\hline 1615 & 1 & 20 & 44 & 6 & 6 \\
\hline 1669 & 34 & 38 & 44 & 11 & 11 \\
\hline 1672 & 25 & 25 & 26 & 22 & 22 \\
\hline 1683 & 14 & 27 & 39 & 12 & 12 \\
\hline 1688 & 53 & 53 & 54 & 16 & 16 \\
\hline 1712 & 52 & 54 & 58 & 8 & 8 \\
\hline 1725 & 34 & 34 & 39 & 24 & 24 \\
\hline 1729 & 33 & 46 & 57 & 16 & 16 \\
\hline 1774 & 41 & 43 & 43 & 22 & 23 \\
\hline 1790 & 52 & 60 & 62 & 20 & 16 \\
\hline 1792 & 31 & 41 & 48 & 4 & 4 \\
\hline 1800 & 30 & 43 & 44 & 12 & 12 \\
\hline 1806 & 59 & 60 & 62 & 11 & 11 \\
\hline 1851 & 24 & 26 & 26 & 14 & 14 \\
\hline 1854 & 42 & 44 & 47 & 15 & 15 \\
\hline 1865 & 30 & 31 & 31 & 6 & 9 \\
\hline 1874 & 24 & 34 & 32 & 11 & 11 \\
\hline 1875 & 28 & 34 & 36 & 14 & 14 \\
\hline 1877 & 26 & 27 & 27 & 7 & 7 \\
\hline 1897 & 16 & 30 & 30 & 33 & 35 \\
\hline
\end{tabular}




\section{APPENDIX E}

\section{INFERENTIAL TEST RESULTS}

CORRELATION between Density and Connectivity Measures:

Null Hypothesis states that the true Correlation Coefficient is equal to zero:

1925 Pearson: 0.506

1925 Kendall's Tau: 0.428

1925 Spearman's Rho: 0.581

1936 Pearson: 0.429

1936 Kendall's Tau: 0.340

1936 Spearman's Rho: 0.480

1945 Pearson: 0.180

1945 Kendall's Tau: 0.142

1945 Spearman's Rho: 0.203
Significance $=0.000$

Reject Null at $99 \%$ Confidence

Significance $=0.000$

Reject Null at $99 \%$ Confidence

Significance $=0.000$

Reject Null at $99 \%$ Confidence

Significance $=0.000$

Reject Nul1 at 99\% Confidence

Significance $=0.000$

Reject Null at $99 \%$ Confidence

Significance $=0.000$

Reject Null at $99 \%$ Confidence

Significance $=0.049$

Reject Null at 95\% Confidence

Significance $=0.026$

Reject Null at $95 \%$ Confidence

Significance $=0.026$

Reject Null at 95\% Confidence

NORMALITY:

Null Hypothesis states that the data come from a population with normal distribution:

1925 Dwelling Density:

Kolmogorov-Smirnov
Skewness: 0.615

Significance $=0.055$

Cannot Reject Null at 95\% Confidence 
Shapiro-Wilk

1936 Dwelling Density:

Kolmogorov-Smirnov

Shapiro-Wilk

1945 Dwelling Density:

Kolmogorov-Smirnov

Shapiro-Wilk

1925 Street Connectivity:

Kolmogorov-Smirnov

Shapiro-Wilk

1936 Street Connectivity:

Kolmogorov-Smirnov

Shapiro-Wilk

1945 Street Connectivity:

Kolmogorov-Smirnov

Shapiro-Wilk
Significance $=0.001$

Reject Null at $95 \%$ Confidence

Skewness: 0.088

Significance $=0.200$

Cannot Reject Null at $95 \%$ Confidence

Significance $=0.454$

Cannot Reject Null at $95 \%$ Confidence

Skewness: -0.009

Significance $=0.200$

Cannot Reject Null at 95\% Confidence

Significance $=0.872$

Cannot Reject Null at 95\% Confidence

Skewness: 0.573

Significance $=0.004$

Reject Null at 95\% Confidence

Significance $=0.001$

Reject Null at 95\% Confidence

Skewness: 0.587

Significance $=0.005$

Reject Null at 95\% Confidence

Significance $=0.002$

Reject Null at $95 \%$ Confidence

Skewness: 0.585

Significance $=0.001$

Reject Null at 95\% Confidence

Significance $=0.002$

Reject Null at 95\% Confidence 
HOMOSCEDASTICITY:

Null Hypothesis states that the data come from populations with equal variance:

Dwelling Density:

Levene's Statistic

Significance based on Mean $=0.663$

Cannot Reject Null at $95 \%$ Confidence

Significance based on Median $=0.650$

Cannot Reject Null at 95\% Confidence

Street Connectivity:

Levene's Statistic

Significance based on Mean $=0.690$

Cannot Reject Null at 95\% Confidence

Significance based on Mean $=0.721$

Cannot Reject Null at 95\% Confidence

TESTS COMPARING CELLS IN RELATION TO DISTANCE TO STREETCAR:

ANOVA:

Null Hypothesis states that the means of the populations are equal:

Critical Value at $95 \%$ confidence: $\mathrm{F}=3.07$

Dwelling Density:

Streetcar Distance Class $=1 \quad$ Significance $=0.052$

Test Statistic $=3.06 \quad$ Cannot Reject Null at $95 \%$ Confidence

Streetcar Distance Class $=2 \quad$ Significance $=0.051$

Test Statistic $=3.07 \quad$ Cannot Reject Null at 95\% Confidence

(Note: Critical Value based on more restrictive degrees of freedom)

Streetcar Distance Class $=3 \quad$ Significance $=0.000$

Test Statistic $=7.94 \quad$ Reject Null at $95 \%$ Confidence

Streetcar Distance Class $=4 \quad$ Significance $=0.000$ 
Test Statistic $=16.56$

Street Connectivity:

Streetcar Distance Class $=1$

Test Statistic $=0.40$

Streetcar Distance Class $=2$

Test Statistic $=0.04$

Streetcar Distance Class $=3$

Test Statistic $=1.53$

Streetcar Distance Class $=4$

Test Statistic $=7.91$
Reject Null at 95\% Confidence

Significance $=0.675$

Cannot Reject Null at 95\% Confidence Significance $=0.965$

Cannot Reject Null at 95\% Confidence

Significance $=0.223$

Cannot Reject Null at 95\% Confidence

Significance $=0.001$

Reject Null at 95\% Confidence

\section{KRUSKAL-WALLIS:}

Null Hypothesis states that the medians of the populations are equal:

Critical Value: $\mathrm{H}=5.99$

Street Connectivity:

Streetcar Distance Class $=1$

Test Statistic $=0.69$

Streetcar Distance Class $=2$

Test Statistic $=0.03$

Streetcar Distance Class $=3$

Test Statistic $=5.36$

Streetcar Distance Class $=4$

Test Statistic $=16.26$
Significance $=0.708$

Cannot Reject Null at 95\% Confidence

Significance $=0.985$

Cannot Reject Null at 95\% Confidence

Significance $=0.065$

Cannot Reject Null at 95\% Confidence

Significance $=0.000$

Reject Null at 95\% Confidence

\section{MATCHED PAIRS:}

All null hypotheses are accepted at $95 \%$ confidence. D naught represents the lowest estimation of the difference in means, in intervals of 0.5 , needed to not reject the null hypothesis. 
Dwelling Density:

One-tailed Critical Value: $\mathrm{T}=1.699$

Streetcar Distance Class $=1$

$$
\begin{array}{llll}
\text { 1925-1936 } & \text { D naught }=4 & \mathrm{~T}=1.27 & \text { Significance }=0.102 \\
\text { 1936-1945 } & \text { D naught }=1.5 & \mathrm{~T}=1.13 & \text { Significance }=0.129 \\
\text { 1925-1945 } & \text { D naught }=5.5 & \mathrm{~T}=1.58 & \text { Significance }=0.064
\end{array}
$$

Streetcar Distance Class $=2$

$$
\begin{array}{llll}
\text { 1925-1936 } & \text { D naught }=5 & \mathrm{~T}=1.24 & \text { Significance }=0.108 \\
1936-1945 & \text { D naught }=2 & \mathrm{~T}=1.53 & \text { Significance }=0.063 \\
1925-1945 & \text { D naught }=7.5 & \mathrm{~T}=1.37 & \text { Significance }=0.086
\end{array}
$$

Streetcar Distance Class $=3$

$\begin{array}{llll}1925-1936 & \text { D naught }=6 & \mathrm{~T}=1.57 & \text { Significance }=0.058 \\ 1936-1945 & \text { D naught }=5.5 & \mathrm{~T}=1.49 & \text { Significance }=0.068 \\ 1925-1945 & \text { D naught }=13 & \mathrm{~T}=1.54 & \text { Significance }=0.062\end{array}$

Streetcar Distance Class $=4$

$$
\begin{array}{llll}
\text { 1925-1936 } & \text { D naught }=7 & \mathrm{~T}=1.46 & \text { Significance }=0.072 \\
1936-1945 & \text { D naught }=5.5 & \mathrm{~T}=1.52 & \text { Significance }=0.064 \\
1925-1945 & \text { D naught }=13.5 & \mathrm{~T}=1.63 & \text { Significance }=0.052
\end{array}
$$

Street Connectivity:

One-tailed Critical Value $=1.699$

Streetcar Distance Class $=1$

$$
\begin{array}{llll}
\text { 1925-1936 } & \text { D naught }=1 & \mathrm{~T}=-0.95 & \text { Significance }=0.172 \\
1936-1945 & \text { D naught }=1 & \mathrm{~T}=-1.11 & \text { Significance }=0.134 \\
1925-1945 & \text { D naught }=2 & \mathrm{~T}=-1.50 & \text { Significance }=0.067
\end{array}
$$

Streetcar Distance Class $=2$

$$
\begin{array}{llll}
\text { 1925-1936 } & \text { D naught }=0.5 & \mathrm{~T}=-0.76 & \text { Significance }=0.224 \\
1936-1945 & \text { D naught }=0.5 & \mathrm{~T}=-0.90 & \text { Significance }=0.183 \\
1925-1945 & \text { D naught }=1 & \mathrm{~T}=-0.91 & \text { Significance }=0.179
\end{array}
$$


Streetcar Distance Class $=3$

$$
\begin{array}{llll}
\text { 1925-1936 } & \text { D naught }=2 & T=-1.05 & \text { Significance }=0.148 \\
\text { 1936-1945 } & \text { D naught }=1.5 & T=0.99 & \text { Significance }=0.163 \\
\text { 1925-1945 } & \text { D naught }=2.5 & T=1.17 & \text { Significance }=0.120
\end{array}
$$

Streetcar Distance Class $=4$

$$
\begin{array}{llll}
\text { 1925-1936 } & \text { D naught }=2 & \mathrm{~T}=1.57 & \text { Significance }=0.058 \\
\text { 1936-1945 } & \text { D naught }=1.5 & \mathrm{~T}=1.26 & \text { Significance }=0.104 \\
\text { 1925-1945 } & \text { D naught }=4.5 & \mathrm{~T}=1.28 & \text { Significance }=0.100
\end{array}
$$

\section{WILCOXON:}

Null hypothesis states that the medians of the populations are equal.

Street Connectivity:

Streetcar Distance Class $=1$

1925-1936 Test Statistic $=-13$ Critical Interval: $T=+/-18.70$

Significance $=0.173$

1936-1945 Test Statistic $=-16$ Critical Interval: $\mathrm{T}=+/-18.70$

Significance $=0.093$

1925-1945 Test Statistic $=-53$ Critical Interval: $T=+/-49.97$

Significance $=0.037$

Cannot Reject Nulls at 95\% Confidence except 1925-1945

Streetcar Distance Class $=2$

$$
\begin{aligned}
& \text { 1925-1936 Test Statistic }=-6 \quad \text { Critical Interval: } \mathrm{T}=+/-10.74 \\
& \text { Significance }=0.257 \\
& \text { 1936-1945 Test Statistic }=0 \quad \text { Critical Interval: } T=+/-7.33 \\
& \text { Significance }=1.000 \\
& \text { 1925-1945 Test Statistic }=-1 \quad \text { Critical Interval: } T=+/-18.70 \\
& \text { Significance }=0.914
\end{aligned}
$$




$$
\begin{aligned}
& \text { Streetcar Distance Class }=3 \\
& \text { 1925-1936 Test Statistic }=-55 \text { Critical Interval: } \mathrm{T}=+/-38.46 \\
& \text { Significance }=0.005 \\
& \text { 1936-1945 Test Statistic }=-89 \text { Critical Interval: } \mathrm{T}=+/-62.44 \\
& \text { Significance }=0.003 \\
& \text { 1925-1945 Test Statistic }=-124 \text { Critical Interval: } \mathrm{T}=+/-75.81 \\
& \text { Significance }=0.001 \\
& \text { Reject All Nulls at 95\% Confidence } \\
& \text { Streetcar Distance Class }=4 \\
& \text { 1925-1936 Test Statistic }=-149 \text { Critical Interval: } \mathrm{T}=+/-82.81 \\
& \text { Significance }=0.000 \\
& \text { 1936-1945 Test Statistic }=-95 \text { Critical Interval: } \mathrm{T}=+/-62.44 \\
& \text { Significance }=0.003 \\
& \text { 1925-1945 Test Statistic }=-231 \text { Critical Interval: } \mathrm{T}=+/-112.78 \\
& \text { Significance }=0.000 \\
& \text { Reject All Nulls at 95\% Confidence }
\end{aligned}
$$

\section{INDEPENDENT SAMPLES:}

Null Hypothesis states that the means of the populations are equal:

Critical Value at $95 \%$ confidence: $\mathrm{T}=1.658$

Dwelling Density:

1925 Streetcar Distance Groups 1 and 2

Significance $=0.000$

Test Statistic $=7.35 \quad$ Reject Null at $95 \%$ confidence

1936 Streetcar Distance Groups 1 and 2

Significance $=0.000$

Test Statistic $=5.26 \quad$ Reject Null at $95 \%$ confidence

1945 Streetcar Distance Groups 1 and 2

Significance $=0.000$ 
Test Statistic $=3.51 \quad$ Reject Null at $95 \%$ confidence

(Note: Notice that the test statistics are getting smaller with time)

1925 Streetcar Distance Group 1 and 1945 Streetcar Distance Group 2

Significance $=0.778$

Test Statistic $=0.28 \quad$ Cannot Reject Null at 95\% confidence

Street Connectivity:

1925 Streetcar Distance Groups 1 and 2

Significance $=0.000$

Test Statistic $=3.66 \quad$ Reject Null at $95 \%$ confidence

1936 Streetcar Distance Groups 1 and 2

Significance $=0.042$

Test Statistic $=2.05 \quad$ Reject Null at $95 \%$ confidence

1945 Streetcar Distance Groups 1 and 2

Significance $=0.680$

Test Statistic $=0.41 \quad$ Cannot Reject Null at $95 \%$ confidence

1925 Streetcar Distance Group 1 and 1945 Streetcar Distance Group 2

Significance $=0.776$

Test Statistic $=0.28 \quad$ Cannot Reject Null at 95\% confidence

1936 Streetcar Distance Group 1 and 1945 Streetcar Distance Group 2

Significance $=0.919$

Test Statistic $=0.10 \mathrm{C} \quad$ Cannot Reject Null at $95 \%$ confidence

\section{MANN-WHITNEY:}

Null Hypothesis states that the medians of the populations are equal:

Critical Interval at $95 \%$ confidence: $3257<\mathrm{S}<4003$

Street Connectivity:

1925 Streetcar Distance Groups 1 and 2

Significance $=0.000$

Test Statistic $=4451.5 \quad$ Reject Null at $95 \%$ confidence 
1936 Streetcar Distance Groups 1 and 2

Significance $=0.008$

Test Statistic $=4136.5 \quad$ Reject Null at $95 \%$ confidence

1945 Streetcar Distance Groups 1 and 2

Significance $=0.441$

Test Statistic $=3776.5 \quad$ Cannot Reject Null at $95 \%$ confidence

1925 Streetcar Distance Group 1 and 1945 Streetcar Distance Group 2

Significance $=0.912$

Test Statistic $=3651 \quad$ Cannot Reject Null at $95 \%$ confidence

1936 Streetcar Distance Group 1 and 1945 Streetcar Distance Group 2

Significance $=0.640$

Test Statistic $=3719 \quad$ Cannot Reject Null at $95 \%$ confidence

TESTS COMPARING CELLS IN RELATION TO DISTANCE TO CITY HALL:

ANOVA:

Null Hypothesis states that the means of the populations are equal:

Critical Value at $95 \%$ confidence: $\mathrm{F}=3.0$

Dwelling Density:

City Hall Distance Group $=1$

Significance $=0.000$

Test Statistic $=11.46 \quad$ Reject Null at 95\% Confidence

City Hall Distance Group $=2$

Significance $=0.000$

Test Statistic $=-11.27 \quad$ Reject Null at $95 \%$ Confidence

Street Connectivity:

City Hall Distance Group $=1$

Significance $=0.322$

Test Statistic $=1.14 \quad$ Cannot reject Null at $95 \%$ Confidence 
City Hall Distance Group $=2$

Significance $=0.000$

Test Statistic $=-14.31 \quad$ Reject Null at 95\% Confidence

\section{KRUSKAL-WALLIS:}

Null Hypothesis states that the medians of the populations are equal:

Critical Value: $\mathrm{H}=5.99$

Street Connectivity:

City Hall Distance Group $=1 \quad$ Significance $=0.326$

Test Statistic $=2.24 \quad$ Cannot Reject Null at 95\% Confidence

City Hall Distance Group $=2 \quad$ Significance $=0.001$

Test Statistic $=13.32 \quad$ Reject Null at $95 \%$ Confidence

\section{MATCHED PAIRS:}

All null hypotheses are accepted at $95 \%$ confidence. D naught represents the estimation of the difference in means, in intervals of 0.5 , needed to not reject the null hypothesis.

Dwelling Density:

One-tailed Critical Value: $\mathrm{T}=1.699$

City Hall Distance Group $=1$

$\begin{array}{llll}\text { 1925-1936 } & \text { D naught }=7 & \mathrm{~T}=1.61 & \text { Significance }=0.054 \\ \text { 1936-1945 } & \text { D naught }=3 & \mathrm{~T}=1.57 & \text { Significance }=0.058 \\ \text { 1925-1945 } & \text { D naught }=10.5 & \mathrm{~T}=1.59 & \text { Significance }=0.056\end{array}$

City Hall Distance Group $=2$

$\begin{array}{llll}\text { 1925-1936 } & \text { D naught }=5 & \mathrm{~T}=1.24 & \text { Significance }=0.107 \\ 1936-1945 & \text { D naught }=5 & \mathrm{~T}=1.40 & \text { Significance }=0.081 \\ \text { 1925-1945 } & \text { D naught }=10.5 & \mathrm{~T}=1.44 & \text { Significance }=0.074\end{array}$

Street Connectivity:

One-tailed Critical Value $=1.699$ 
City Hall Distance Group $=1$

$$
\begin{array}{llll}
\text { 1925-1936 } & \text { D naught }=0.5 & \mathrm{~T}=1.55 & \text { Significance }=0.060 \\
\text { 1936-1945 } & \text { D naught }=0.5 & \mathrm{~T}=-1.34 & \text { Significance }=0.092 \\
1925-1945 & \text { D naught }=1 & \mathrm{~T}=1.59 & \text { Significance }=0.055
\end{array}
$$

City Hall Distance Group $=2$

$$
\begin{array}{llll}
\text { 1925-1936 } & \text { D naught }=2 & \mathrm{~T}=-0.86 & \text { Significance }=0.193 \\
1936-1945 & \text { D naught }=2.5 & \mathrm{~T}=-0.81 & \text { Significance }=0.211 \\
1925-1945 & \mathrm{D} \text { naught }=4.5 & \mathrm{~T}=-1.06 & \text { Significance }=0.145
\end{array}
$$

\section{WILCOXON:}

Null hypothesis states that the medians of the populations are equal.

Street Connectivity:

City Hall Distance Group $=1$

$$
\begin{array}{rlr}
\text { 1925-1936 } & \text { Test Statistic }=-78 & \text { Critical Interval: } T=+/-56.09 \\
\text { Significance }=0.006 & \\
\text { 1936-1945 } & \text { Test Statistic }=-59 & \text { Critical Interval: } T=+/-44.09 \\
\text { Significance }=0.020 & \\
\text { 1925-1945 Test Statistic }=-145 & \text { Critical Interval: } T=+/-90.01 \\
\text { Significance }=0.002 & \\
\text { Reject All Nulls at } 95 \% \text { Confidence } &
\end{array}
$$

City Hall Distance Group $=2$

$$
\begin{array}{rlr}
\text { 1925-1936 } & \text { Test Statistic }=-276 & \text { Critical Interval: } \mathrm{T}=+/-137.2 \\
\text { Significance } & =0.000 & \\
\text { 1936-1945 } & \text { Test Statistic }=-293 & \text { Critical Interval: } \mathrm{T}=+/-163.16 \\
\text { Significance } & =0.000 & \\
1925-1945 & \text { Test Statistic }=-627 & \text { Critical Interval: } \mathrm{T}=+/-239.84 \\
\text { Significance } & =0.000 & \\
\text { Reject All Nulls at } 95 \% \text { Confidence } &
\end{array}
$$


INDEPENDENT SAMPLES:

Null Hypothesis states that the means of the populations are equal:

Critical Value at $95 \%$ confidence: $\mathrm{T}=1.658$

Dwelling Density:

1925 City Hall Distance Groups 1 and 2

Significance $=0.000$

Test Statistic $=5.23 \quad$ Reject Null at $95 \%$ confidence

1936 City Hall Distance Groups 1 and 2

Significance $=0.000$

Test Statistic $=6.83 \quad$ Reject Null at $95 \%$ confidence

1945 City Hall Distance Groups 1 and 2

Significance $=0.000$

Test Statistic $=6.18 \quad$ Reject Null at $95 \%$ confidence

1925 City Hall Distance Group 1 and 1945 City Hall Distance Group 2

Significance $=0.582$

Test Statistic $=0.55 \quad$ Cannot Reject Null at $95 \%$ confidence

Street Connectivity:

1925 City Hall Distance Groups 1 and 2

Significance $=0.000$

Test Statistic $=3.61 \quad$ Reject Null at $95 \%$ confidence

1936 City Hall Distance Groups 1 and 2

Significance $=0.001$

Test Statistic $=3.46 \quad$ Reject Null at $95 \%$ confidence

1945 City Hall Distance Groups 1 and 2

Significance $=0.025$

Test Statistic $=2.28 \quad$ Reject Null at $95 \%$ confidence

1925 City Hall Distance Group 1 and 1945 Streetcar Distance Group 2

Significance $=0.582$

Test Statistic $=0.55 \quad$ Cannot Reject Null at $95 \%$ confidence 


\section{MANN-WHITNEY:}

Null Hypothesis states that the medians of the populations are equal:

Critical Interval at $95 \%$ confidence $=3378<\mathrm{S}<4124$

Street Connectivity:

1925 City Hall Distance Groups 1 and 2

Significance $=0.001$

Test Statistic $=4360 \quad$ Reject Null at $95 \%$ confidence

1936 City Hall Distance Groups 1 and 2

Significance $=0.002$

Test Statistic $=4354 \quad$ Reject Null at $95 \%$ confidence

1945 City Hall Distance Groups 1 and 2

Significance $=0.055$

Test Statistic $=4112 \quad$ Cannot Reject Null at $95 \%$ confidence

1925 City Hall Distance Group 1 and 1945 Streetcar Distance Group 2

Significance $=0.811$

Test Statistic $=3796.5 \quad$ Cannot Reject Null at $95 \%$ confidence 